UNIVERSIDADE DE SÃO PAULO

ESCOLA DE COMUNICAÇÕES E ARTES

CLÉBER EDUARDO MIRANDA DOS SANTOS

O "modelo egológico" no documentário brasileiro: a individualização pela rentabilidade cênica em Estamira e A pessoa é para o que nasce 


\title{
O "modelo egológico" no documentário brasileiro: a individualização pela rentabilidade cênica em Estamira e A pessoa é para o que nasce
}

\begin{abstract}
Dissertação apresentada ao Programa de Pós-Graduação em Ciências da Comunicação da Escola de Comunicações e Artes da Universidade de São Paulo, como requisito parcial para obtenção do título de Mestre. Área de concentração: Estudo dos Meios e da Produção Mediática.
\end{abstract}

Orientador: Prof. Dr. Ismail Norberto Xavier

SÃO PAULO,

2011 
Autorizo a reprodução e divulgação total ou parcial deste trabalho, por qualquer meio convencional ou eletrônico, para fins de estudo e pesquisa desde que citada a fonte.

\section{Catalogação na publicação \\ Serviço de Biblioteca e Documentação \\ Escola de Comunicações e Artes da Universidade de São Paulo}

Santos, Cléber Eduardo Miranda dos

O modelo egológico no documentário brasileiro : a individualização pela rentabilidade cênica em Estamira e A pessoa é para o que nasce / Cléber Eduardo Miranda dos Santos - São Paulo : C. E. M. Santos, 2011.

100 p. : il.

Dissertação (Mestrado) - Escola de Comunicações e Artes / Universidade de São Paulo.

Orientador: Ismail Norberto Xavier

1. Documentário 2. Personagem 3. Performance 4. Individualização 5. Cinema brasileiro I. Xavier, Ismail Norberto II. Título

CDD 21.ed. -791 
O "modelo egológico" no documentário brasileiro: a individualização pela rentabilidade cênica em Estamira e $A$ pessoa é para o que nasce

Cléber Eduardo Miranda dos Santos

Dissertação apresentada ao Programa de Pós-Graduação em Ciências da Comunicação da Escola de Comunicações e Artes da Universidade de São Paulo, como requisito parcial para obtenção do título de Mestre. Área de concentração: Estudo dos Meios e da Produção Mediática.

Aprovado em:

\section{Banca examinadora:}

Prof. Dr:

Instituição:

Assinatura:

Prof. Dr:

Instituição:

Assinatura:

Prof. Dr:

Instituição:

Assinatura: 


\section{AGRADECIMENTOS}

ao pai, Antonio Carlos (in memorian), e à mãe, Maridelva, pela educação, afeto e cuidado, sempre acreditando que eu era melhor do que eu sempre fui.

à esposa, companheira e parceira, Ilana Feldman, pelo estímulo, amor, paciência e apoio nas decisões, assim como pela ajuda na formatação final.

à sogra Keyla, que um dia disse "você tem de fazer mestrado e doutorado".

ao orientador Ismail Xavier, pela aceitação e pela confiança, pelos textos escritos ao longo da jornada como pensador de cinema, fundamentais para a formação do que sou.

à amiga e colega Renata Gomes, pela força em meu ingresso na atividade docente.

à Ana Giannasi, colega e ex-coordenadora do curso de audiovisual do Senac, pela coragem do convite para habitar uma sala de aula.

à atual coordenadora Nanci Barbosa, pela compreensão na reta final.

aos ex-alunos (muito especiais) Renan Lima, Natalia Vestri, Bruno Schiavon e Patricia Black, pela ajuda na revisão, formatação e na pesquisa de dados, assim pela manutenção da crença na renovação.

aos meus melhores amigos (e companheiros de crises em relação à crítica), Francis Vogner dos Reis e Paulo Santos Lima, pelas conversas e pelo respeito.

a Jean-Claude Bernardet, pelas posturas inspiradoras, contundentes e constantes, apesar da distância e das diferenças de olhar e posicionamento.

a Jacques Rivette, por um dia ter escrito o artigo "Da abjeção", que foi propulsor do tom e do enfoque da pesquisa.

a Eduardo Valente, pelas parcerias críticas e pelo convite para dividir a curadoria de duas mostras, sem as quais os estímulos teriam sido menos potentes.

e aos meus alunos do Senac e colegas de disciplinas da ECA, que, mesmo sem saberem, foram de fundamental importância para esse processo. 


\section{RESUMO}

Essa dissertação tem por objetivo colocar em perspectiva crítica e histórica o fenômeno da individualização de personagens no documentário contemporâneo, muitos elevados a título dos filmes, e o critério de seleção desses personagens por valores como carisma, talento e rentabilidade cênica, em sintonia com a noção de performance em sentido amplo (inclusive empresarial). Os filmes centrais para essa discussão são Estamira (2006), de Marcos Prado, e A pessoa é para o que nasce (2006), de Roberto Berlinner, ambos protagonizados por mulheres em situação de déficit social e orgânico, mas inseridas em uma dinâmica de superávit cênico e produtivo, como auto-empreendedoras que trabalham para ter imagem. Nesses dois documentários, e em alguns outros, impõese um "modelo egológico", centrado nos indivíduos, sem muitas implicações sociais. A pesquisa não lida apenas com uma circunscrição do documentário nos anos 2000, operando ainda um breve panorama histórico do documentário brasileiro posterior a Cabra marcado para morrer (1984), de Eduardo Coutinho, além de analisar uma mudança de estratégias de enfoque na comparação com a linhagem moderna dos anos 1960, conectada ao Cinema Novo, quando o "outro de classe" era abordado em uma perspectiva política e social, com o posicionamento dos filmes por meio de um locutor associado a um saber, procedimento classificado por Jean-Claude Bernardet como modelo sociológico.

Palavras-chave: 1. Documentário 2. Personagem 3. Performance 4. Individualização 5. Cinema brasileiro 


\begin{abstract}
The objective of this dissertation is to place the phenomenon of characters' individualization in the contemporary documentary inside a critic and historical perspective, transforming many times the name of the character in the name of the movie, and to discuss the selection criterion of these characters by values as charisma, talent or scenic's profitability, in tune with the notion of performance in a broad sense (inclusive in a business sense). The central movies of this discussion are Marcos Prado's Estamira (2006) and Roberto Berlinner's A pessoa é para o que nasce (2006), both with principal female characters that are inserted in a social and organic deficit situation, but, still, in a dynamics of scenic and productive superavit, acting as selfentrepreneurial that build their own images. In these documentaries and others are imposed a self-logical model, centered in the individuals, without many social implications. The research doesn't deal only with a documentary circumscription in the 2000 's, operating still in a brief historical panorama of the Brazilian documentary that follows Cabra marcado para morrer (1984) and analyzing a strategy change of focus in comparison with the 1960's modern lineage, connected into the Cinema Novo, when the another of lower class was approached in a political and social situation and placing the movie through a narrator that were associated with a knowledge, procedure that is classified by Jean-Claude Bernardet as sociological model.
\end{abstract}

Key-words: 1. Documentary 2. Character 3. Performance 4. individualization 5. Brazilian cinema 


\section{SUMÁRIO}

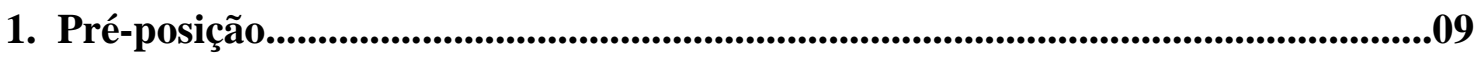

Uma mise en scéne da escrita

2. Do estímulo ao estilo

Recusa do autor como método

Esboço de um presente

Intervalo 1: o mar

Pequeno mapeamento do documentário brasileiro dos 2000

Intervalo 2: O pós-Cabra

Dispositivo: disposições para descontrole

3. Do modelo sociológico ao "egológico"

Intervalo 3 - identidades

Intervalo 4: o som direto nos anos 1960

Intervalo 5: duas conversas sobre documentário

Intervalo 6 - retrato, micro história

Intervalo 7 - a entrevista, o poder e a mise en scène

4. Qual seu talento?

A ditadura da rentabilidade em nome da democracia cênica

Intervalo 8: eu produzo, logo existo

Documentário de personagem: quem vende e quem trabalha?

Intervalo 9: Estamira (a pessoa) é para o que nasce

5. Epílogo: a performance estética.

Anexos.

Referências bibliográficas 


\section{Pré-posição}

Por que não introdução? Porque só se introduz o que está para começar, não processos em andamento, que é o caso menos dessa pesquisa, mais do universo enfocado (o documentário brasileiro contemporâneo), em constante movimento e modificação. Ele está em processo. Optar por pré-posição não é apenas iniciar o texto de um modo menos convencional, mas fazê-lo com a demarcação já de uma postura: nos capítulos seguintes, mesmo quando lidar com dados objetivos e factuais, posições serão tomadas. Portanto, antes de tomá-las, vou me pré-posicionar, forma de explicar certo caminho e certo contexto, que prossegue no capítulo 2.

No momento dessa escrita, o mundo vive determinado momento, não apenas composto de fatos midiáticos, mas marcados por eles: terrorismo na Noruega, crise econômica na Europa e nos EUA, massacre de opositores à tirania na Síria, imagens da miséria em pontos da África, primeira mulher presidente (ou presidenta) do país (Dilma Roussef), espancamentos de homossexuais em São Paulo. Mas o mundo, o que chamamos de realidade, sem tantas relativizações conceituais, não é apenas composto por fatos, sequer apenas por estes fatos relacionados. Até porque esse mundo nos é apresentado por intermediários (os meios de comunicação). Nosso contato com o mundo, ou com a realidade, é cada vez mais virtual. Vemos as imagens e ouvimos comentários, testemunhos, no aparelho de TV, em nossos computadores, celulares, ipods e outras invenções recentes de conexão com a "realidade".

Talvez isso explique, entre tantas outras razões imbricadas, a inflação do "eu": uma tentativa de encontrar uma voz e uma imagem particular, de sua experiência, em um mundo no qual a experiência está virtualizada, em geral com imagens e discursos standard, tornadas oficiais pela repetição ou por sua conformação e conformidade. Portanto, existem os fatos e existem as mentalidades, que tanto são mobilizadoras dos fatos como são resultados de uma circulação desses fatos no mundo.

Repetindo o início, no momento dessa escrita, o mundo vive um momento, não apenas composto de fatos midiáticos. Há nesse mesmo mundo formas mais presentes ou mais ausentes de configuração das relações de trabalho, da economia, da política. Há ainda formas de percepção do funcionamento desse mundo, formas discursivas e 
práticas em relação ao lugar do indivíduo na sociedade como cidadão crítico, em relação ao lugar do cinema (e da imagem) nessas configurações amplas e, consequentemente, em relação às formas de pensar o cinema. E o documentário, especificamente.

Insistindo: existem os fatos e as mentalidades, as evidências capturáveis e numeráveis (talvez até mensuráveis por estatísticas), assim como o pensamento em torno dessas evidências, propositivos ou reativos, que compõem esse momento do mundo. Essa insistência na valorização desse momento (primeira para segunda década do século XXI), a rigor, tem por objetivo valorizar as contingências. Tanto os estímulos da escrita em curso nascem desse momento, em reação a ele, como a escrita é parcialmente formatada por "seu" momento: contingências gerais e específicas nas quais seu processo foi desenvolvido.

As contingências gerais dizem respeito ao momento histórico de forma mais ampla, ou seja, aos movimentos factuais e de mentalidade do mundo nos últimos 50 anos, obviamente co-responsáveis por qualquer subjetividade do olhar, da reflexão sobre esse olhar e de um pensamento a partir das reflexões. Nessa amplitude histórica, há o cinema desde 1960, com som direto no documentário, com as modernizações todas também na ficção, curtos-circuitos na estrutura da narrativa (em relação à reordenação ou desordenamento do tempo dramático), espelhamento do próprio processo de construção (Godard, Resnais), valorização de um gênio criativo acima das determinações econômicas (a política dos autores), as heranças do neorrealismo e os efeitos da Nouvelle Vague reciclados por cineastas não-europeus, o Cinema Novo no Brasil e todo um ganho de complexidade na forma de colocar o cinema no mundo.

Um cinema posterior a 1960, já consciente e desconfiado de seu lugar no mundo, na história das artes e em sua própria história, transformado em campo de batalha crítica e teórica, sobretudo em torno de suas relações com a realidade (ampla ou específica). De Munstenberg a Vertov, de Epstein a Bazin, de Deluc a Zavattini, de Eisenstein a Rivette, as principais divergências discursivas sobre o cinema seguem essa tônica. Como colocar as imagens em suas relações com o referente? Menos questão de "o que é o cinema?" (de Bazin) e mais questão de "por que e para que o cinema"? Questão, sempre, de modo (maneira). Portanto, no momento dessa escrita, no período de vida de seu autor, o cinema tem uma história. E só a tem porque tem historiadores, críticos, 
analistas, teóricos, uma herança de pensamentos, fundamentais e inspiradores dessa escrita. Não se pode perder isso de vista.

Nesse espectro de 50 anos, nessa idade do som direto, do cinema moderno, da política dos autores, de uma antropologia amadora por parte dos documentaristas, de todas as mudanças tecnológicas e alterações estéticas nas décadas seguintes a 1950, há outros momentos. Poderíamos elencar alguns tantos em contingências específicas (como a Nova Hollywood no fim dos anos 60, como o Cinema de Invenção no Brasil), mas iremos especificar, para essa escrita, apenas uma transição tecnológica, que em alguma medida altera certas formas de captação e os próprios resultados dos filmes: a progressiva transição da captação em película $(16 \mathrm{~mm}$ ou $35 \mathrm{~mm})$ para o digital (ou numérique), que não é questão central para a pesquisa, mas é contexto considerável.

No momento dessa escrita, jovens estudantes de cinema de 19 a 21 anos, em seus trabalhos universitários, usam suas próprias câmeras, 5 ou 7 D, com qualidade superior às oferecidas pelos cursos. Editam imagem e som em casa, em seus próprios computadores. Podem filmar seus atores e seus personagens (em ficção ou documentário) sem sequer colocar o olho no visor. Consequentemente, a câmera pode ser direcionada a partir de qualquer ângulo e altura, sem o operador precisar se agachar ou fazer esforços físicos. Um momento em que o enquadramento, de certa forma, liberta-se da necessidade do olhar. Momento em que o olhar, antes extensão de um corpo e de uma sensibilidade, torna-se mais questão de técnica: como usar com menos esforço as possibilidades de uma máquina captadora de imagens?

Uma pausa para um caso sintomático desses novos e nossos tempos. Em um recente artigo de Adrian $\operatorname{Martin}^{1}$, o crítico australiano reage a afirmações que o dinamarquês Lars von Trier dá nos extras do DVD da comédia $O$ grande chefe $(2006)^{2}$, em que o cineasta defende o emprego de uma técnica de "automatovision", um ordenador que, de modo aleatório, estabelece na câmera os parâmetros de composição do plano. Ainda nos extras, Von Trier afirma que, com o passar dos anos, deu-se conta de que a noção de enquadramento não tem lógica, nenhum sentido, é opressivo.

\footnotetext{
1 O artigo de Adrian Martin, intitulado "El Enquadre", foi publicado na seção "Scanner" da edição de julho-agosto da Cahiers du Cinéma España, p.39)

${ }_{2} O$ grande chefe (Directoren for det hele)
} 
Martin reage ao disparate, associando Von Trier a outro sintoma contemporâneo: a câmera na mão em constante movimento que, de fato, atenta contra a noção de quadro e de plano, substituída pela de sacudidas e perdas de foco. No final do artigo, Martin afirma que o que está ameaçado, com essa autonomia das máquinas em relação a um pensamento, idéias e métodos, é a mise en scène, a organização do espaço e dos corpos no espaço, que toma tempo demais e põe em risco a necessidade de rodar muito, grande quantidade de material, sem necessariamente muita preparação.

Não transformemos o caso particular em regra geral, mas ele também não pode ser ignorado. Basta lembrar que, no documentário como na ficção, uma palavra-chave forte e fundamental, não de hoje, mas fortemente nos últimos anos, é o acaso. E também não podemos ignorar que, no caso de pelo menos dois documentários contemporâneos, Edificio Master (2002), de Eduardo Coutinho, e Nelson Freire (2003), de João Moreira Salles, têm em seus DVDs uma alternativa de estrutura randômica, tornando aleatória a ordem das imagens nos dois filmes. As novas tecnologias dão as mãos, portanto, à aleatoriedade e à casualidade.

Esse cultivo de um descontrole e de uma recusa a esquematizações, roteirizações e construções de sentido a partir de fragmentos, de presenças e de frases tem se tornado mais intensa e mais freqüente nos últimos. Há um anti-teleologia bastante generalizada. Talvez, em parte pelo menos, os estudos do documentário, em algumas de suas vertentes (a dos novos pesquisadores do campo, surgidos nos últimos dez anos), valorize pensadores, como Jean-Louis Comolli e sua defesa dos "riscos do real", que, em última instância, procuram o que resta do sujeito, em meio às determinações do capitalismo e à homogenização serializada.

Algumas noções-chave como "encontro", "individuação", "dispositivo" e "singularidade" passam a ocupar os textos, quase sempre contrários às noções de representação e representatividade. O documentário passa a ser, nesse sentido, um espaço de recusa, em primeiro lugar, e de proposição do singular, em segundo. Há essa procura de um busca randômica, não pautada, aberta aos acontecimentos relacionais. Longe de ser apenas uma entre outras estratégias, essa abertura torna-se uma política, uma ideologia, uma visão de como as coisas devem ser.

O cinema moderno, o documentário direto e as câmeras-edições digitais. Esse é o momento do cinema a partir do qual partiremos para seguir em frente. Mas há também 
o momento e a mentalidade dos sujeitos geradores de imagens e narrativas (quase todos nós). Um momento de inflação de subjetividades, de blogs testemunhais (de sentimentos, de pensamentos, de ações e inações) e de perfis de facebooks confessionais (uma foto como comprovação de presença: eu estive lá, eu estava com eles, eu existo na imagem), de uma primeira pessoa inserida em certo código narrativo, portanto, cada vez menos desestabilizadora de certas normas, cada vez mais formatada quase como um gênero literário, documental e social.

A primeira pessoa da narração fílmica não é interesse central dessa pesquisa, mas sim a dos personagens filmados pelos documentários (brasileiros e contemporâneos). Eduardo Coutinho é nome chave nesse processo, mas, ao escolher filmes a partir dos quais a pesquisa iria se fundamentar, a seleção recaiu sobre documentários menos legitimados, como Estamira (2005), de Marcos Prado, e A pessoa é para o que nasce (2005), de Roberto Berliner, embora altamente considerados em certos círculos, com boa presença nos espaços de repercussão mais tradicionais (jornais, revistas, sites, blogs, artigos acadêmicos, festivais).

O interesse maior, nada original em uma primeira aproximação, era estudar o óbvio: uma migração dos enfoques por tema ou por universos condicionantes (a questão do negro, do índio, do analfabeto, de classes sociais, de trabalhadores de certa área) para uma abordagem focada na particularidade do indivíduo (não necessariamente conectado a uma estrutura social). As aproximações já feitas por Katia Hollanda entre o novo documentário brasileiro e a micro-história (Holanda, 2004) assim como por Ismail Xavier entre essa produção e uma "etnografia discreta"3, longe de bloquear o estímulo, apenas o potencializou. Porque se o fenômeno era evidente, como diagnóstico geral, seria preciso atentar-se para suas particularidades (as diferenças de operação dentro dessa primeira pessoa do outro), mas também para suas co-relações extra-documentais.

Até onde essa primeira pessoa do outro é uma questão específica do documentário brasileiro? Até onde é questão específica do documentário em geral? Até onde é uma questão do momento histórico, relacionada com a historiografia, com a própria economia da subjetividade, com o estímulo generalizado de performances individuais como auto-gestão (cênica, social, profissional), com uma tradição das artes

\footnotetext{
${ }^{3}$ Entrevista de Mario Sergio Conti com Ismail Xavier na Folha de S. Paulo, caderno Mais!, edição de 3 de dezembro de 2000).
} 
visuais e narrativas muito anteriores ao som direto? Como organizar esse movimento de fechar-se em filmes e abrir-se a um mundo de referências, a princípio exteriores e anteriores aos filmes, mas em uma nova aproximação em sintonia com as mesmas problemáticas (a relação entre as atuais primeiras pessoas e os ensaios de Montaigne e Rousseau, os retratos e auto-retratos, o universo dos ordinários no foto-realismo, a estética do grotesco nas artes visuais)?

É preciso tirar a contemporaneidade de um casulo no qual corremos sempre o risco de colocá-la para melhor enxergá-la em nosso microscópio. É preciso ainda pensar o cinema por suas vizinhanças. O excesso de proximidade nos retira a possibilidade de perspectiva. Lembro da noção de contemporaneidade de Agamben (2009), que pressupõe certa defasagem em relação ao presente para não se fundir a ele. Estranhamento com familiaridade. No entanto, mesmo imbuído desse sentimento de defasagem e estranhamento (nada a ver com saudosismo e recusa às inovações), como não se tornar sintoma, mais que reflexão? Porque qualquer escrita está inscrita em seu momento histórico e em seu meio sócio-cultural (antes mesmo de ser escrita). Como também escrever sem ser apenas inscrito em certa lógica?

Voltemos ao momento e às contingências, lá semeados no início do texto. Levei em consideração um mundo histórico (factual - mentalidades), um processo histórico do documentário (som direto e falas de personagens), um momento histórico do sujeito (formado por sua capacidade de performar). Hora de trazer o mundo para o eu desconfiado da primeira pessoa, do testemunho, "da minha pequena história nessa grande história". Sem mergulhar no sintoma apontado na pesquisa, é honesto não ter receio de ver no texto também a especificidade de sua própria história particular. A começar por um histórico de escrita sobre filmes e sobre cinema de seu autor.

Nada de autobiografia. Apenas a consciência de que, tendo escrito profissionalmente como crítico de cinema por mais de 15 anos na imprensa (jornal e revista), antes de ter dedicado os últimos oito anos a artigos e análises para dois sites (Contracampo e Cinética), parece inevitável essa inscrição na escrita: um estilo, um tom, uma articulação com a qual ela se construiu nesses anos, para não falarmos em um certo tipo de olhar para o cinema também influenciado pelas escritas nesses meios. Talvez algumas das potências desse texto estejam nessa prática anterior, uma certa informalidade estilística e alguma ousadia nas afirmações, mas talvez essa experiência 
na crítica também seja o limite dessa escrita, com os riscos de associações livres em excesso, falta de rigor na sistematização e na estrutura, alguma falta de pudor e excesso de economia na forma de se relacionar com a bibliografia.

$\mathrm{Na}$ crítica, o filme único, com suas particularidades. Na pesquisa acadêmica, quase como forma de compensar esse olhar para uma única obra e em espaço reduzido, corre-se o risco contrário. Abranger filmes demais, olhar o documentário pelos prismas das artes plásticas, dos ensaios literários e de outras formas do próprio cinema, enfim, dar conta de uma bibliografia heterogênea, que, embora faça sentido para quem a articula, nem sempre gera o mesmo efeito para quem lê o texto. O risco da abrangência, quase sempre, é a superficialidade. Não é diferente na própria estrutura narrativa do cinema, que, quando construído em multiplots, dá menos tempo de cena para cada núcleo e cada personagem.

Se iremos lidar com as relações contingenciais dos documentários, com as marcas dessas contingências no corpo dos filmes (marcas evidenciadas ou omitidas) e com os contextos mais amplos das especificidades dos "objetos", então talvez seja preciso começar pelo texto, cujo estilo, esqueleto e organismo está permeado por suas próprias contingências, por seus estímulos e por suas limitações. Uma dissertação é uma relação com seu entorno.

No período da pesquisa, além da atividade acadêmica estrita (créditos, congressos, trabalhos), outras atividades foram chaves, todas ainda ligadas à pesquisa e ao cinema: a realização como um dos curadores de uma mostra de documentários brasileiros dos anos 2000 no Centro Cultural da Caixa no Rio de Janeiro, outra de filmes brasileiros do mesmo período (ficções e documentários) no Centro Cultural Banco do Brasil (Rio e São Paulo) e as aulas de teoria do cinema e de documentário ministradas para os graduandos do curso de audiovisual no Centro Universitário Senac. Experiências essas que, sem estarem diretamente conectadas com a pesquisa específica desenvolvida nesses dois anos e meio, foram fundamentais.

Também é preciso destacar o momento final do processo, quando a pesquisa se encaminhava para sua redação final, em julho de 2011. Um mês pesquisando em Paris, especialmente na Bibliothèque du Film, da Cinémathèque Française, permitiu redirecionar o olhar já quase sedimentado, sobretudo no sentido de relacionar o documentário brasileiro contemporâneo com o pensamento europeu sobre o 
documentário, com as programações dos festivais internacionais, com um contexto diferente no tocante à produção e à circulação dos filmes.

Ainda durante o período da pesquisa, uma movimentação da produção documental brasileira encaminhou-se com maior força para os outros que filmam a si mesmos em vez de serem apenas matérias-primas dos filmes. É caso das produções do Vídeo das Aldeias e dos chamados "filmes de quebrada", que se somam a experiências mais duradouras (oficinas Kinoforum, Nós do Cinema) ou mais recentes, como oficinas de realização em comunidades carentes. A maioria dessas experiências é mediada pelo conhecimento técnico e teórico de pessoas de certo saber, não pertencentes ao mesmo universo dos aprendizes, embora em relação às vezes militante com esse universo. Uma atenção maior para os personagens e para as articulações fílmicas desses trabalhos, por questão de recorte e de tempo, não é desenvolvida nesse trabalho e solicita uma pesquisa posterior.

O fim de toda pesquisa é menos um fim porque a pesquisa acabou, porque conclui tudo a concluir, mas porque existem prazos e convenções institucionais, também eles contingências determinantes do texto e de parte do enfoque. Sem essas convenções, a pesquisa teria sido outra, mas sem elas não teria existido. O que segue adiante é resultado ainda em movimento e ainda em inquietação de um percurso longe de ter fim.

A estrutura dessa dissertação sofreu, após a qualificação, constantes modificações, até o momento final do prazo de entrega. $\mathrm{O}$ enfoque se abriu e se fechou, foi reaberto, novamente se estreitou, depois abriu e fechou simultaneamente. Procurei em primeiro lugar delimitar o campo histórico do documentário brasileiro, levando em consideração algumas importantes produções dos anos 1980 e 1990 para melhor entendimento do percurso movido até os anos 2000 (central para a pesquisa), assim como procurando cotejar os procedimentos analisados em relação com alguns documentários dos anos 60, especialmente Viramundo, de Geraldo Sarno, Maioria absoluta, de Leon Hirszman, e Opinião pública, de Arnaldo Jabor. Apenas no capítulo 3 
entraremos na especificidade da pesquisa, centrada em documentários de personagens pautados pela necessidade de trabalhar bem diante da câmera.

Os anexos dispostos ao fim do texto ajudam a fornecer dados sobre a circulação dos documentários brasileiros dentro e fora do país. Tornam mais evidente esse momento de inflação documental e também a maior presença dessa produção em alguns eventos internacionais. Poucos dias antes de entregar o texto, acessei um artigo de Eduardo Escorel em seu blog da Revista Piauí, no qual o crítico, montador e diretor lamenta a baixa média de público para documentários no cinema. Embora os últimos dez anos tenham conseguidos sucessos de bilheteria para padrões documentais, como Vinicius (mais de 250 mil espectadores) e Janela da alma (mais de 150 mil), não se espere dessa família do cinema nenhum blockbuster nacional. No entanto, a partir do artigo de Escorel, podemos abordar uma situação contingencial.

A quantidade de documentários brasileiros lançados em circuito comercial é algo sem igual na maioria de outros países. Na França, por exemplo, onde o documentário é universo de festivais específicos (Cinéma du Réel, Festival de Marselha), têm publicações próprias e muitos pesquisadores especializados na área, o documentário é problema de TV, acima de tudo. São poucos os documentários estreados em salas de exibição, em geral das grandes marcas autorais, como Roger Depardon, Agnès Varda, Chantal Ackerman, para ficar nos de "casa", e os autores de fora, como Rithy Panh, Jia Zhang-ke, Zhong Hua, Wu Yii-feng, Kim Dong-won. Além dos asiáticos (hoje, a coqueluche da crítica francesa, e também no documentário), há os doc-pops americanos, que, mesmo quando mais próximos da forma televisiva, têm lançamentos em telas grandes. Efeito Michael Moore, certamente.

A situação brasileira é diferente. Em razão de editais para cinema, os docs ambicionam (e muitos conseguem) um lugar na luz da sala escura, independentemente do público. Mesmo casos de co-produção com canais de TV, como Canal Brasil e o programa DOC TV, exibido nas TVs públicas, não abrem mão de uma plataforma cinematográfica. Talvez isso possa estar estimulando uma diversificação significativa da produção em relação aos modos de realização, às escolhas de procedimentos, mas por outro lado cria um certo esvaziamento da luta política pela inserção na TV. 


\section{Uma mise en scéne da escrita}

São muitas as considerações, muitas as alternativas de enfoque, por isso, para não abrir mão de algumas delas, optei por dentro do texto criar Intervalos, espécie de boxes que complementam o texto principal. Os Intervalos ganham essa aparência autônoma, descompartimentada, mas na verdade agem como diálogos em transversais, permitindo maior liberdade ensaística e uma abertura para tocar em questões que, em dado momento da escrita, pareciam atravancar o andamento do texto principal.

Recorro a ensaio de Jorge Larrosa, sobre o ensaísmo na escrita acadêmica, para melhor amparar essa decisão. $\mathrm{O}$ autor trata o ensaio como modelo de escrita excluído dos espaços de saber, o que, segundo seu próprio ensaio, significa um dispositivo de controle de saber pelo controle da linguagem, das práticas de ler e escrever. O conformismo lingüístico, continua Larrosa (2003: 101-115), é expressão de conformismo de pensamento.

Também poderíamos dizer que não há revolta intelectual que não seja também, de alguma forma, uma revolta lingüística, uma revolta no modo de nos relacionarmos com a linguagem e com o que ela nomeia. Ou seja, que não há modo de "pensar de outro modo" que não seja, também, "ler de outro modo" e "escrever de outro modo". (Idem, p.102).

Não vou avançar na reflexão sobre o ensaio, mas somente me engajar nele, à procura de uma escrita que expresse o universo abordado (fragmentado, múltiplo), mas também de uma forma de pensar esse universo, por meio de associações, diálogos, sem extrair disso uma visão calcada em certezas, em dogmas, em caminhos prévios, empenhados em demonstrar uma verdade do processo histórico e estético. Não se trata de ler, de ver e de analisar como uma investigação, como perícias, como detetive de formas sensíveis, mas de propor um diálogo, nem sempre em sintonia com aqueles e com aquilo com o qual se dialoga, mas aberto a chamar uns e outros para uma dança.

O ensaísta problematiza sua própria escrita, suas leituras, porque a linguagem é espaço de experiências, não de confirmações (ADORNO, 2003). Experiências não inviabilizam afirmações. Mas são afirmações livres, sem o compromisso com o certo, com o adequado e com as conformações prévias, ainda que, ao seguir as regras gramaticais e certos protocolos de clareza, algum nível de conformação sempre haverá. Ainda assim, o processo dessa escrita, antes de ser apenas um forma do saber sobre algo (embora seja sempre, em alguma medida), é antes uma forma em gestação constante. 


\section{Do estímulo ao estilo:}

Se do horizonte do nosso mundo são subtraídos conteúdos significativos da realidade, a arte deve necessariamente trabalhar com os que restaram, pois uma representação estética é de fato tanto mais real quanto menos renuncia àquela realidade que se situa fora da esfera estética.

Sigmund Kracauer, O ornamento da massa $(2009, \mathrm{p} .95)^{4}$

Por que estudar o documentário brasileiro contemporâneo por meio de dois filmes centrais, Estamira (2005), de Marcos Prado, e A pessoa é para o que nasce (2005), de Roberto Berliner, entre tantas opções de universos fílmicos à disposição (de outras nacionalidades, outros momentos históricos, de outro valor estético)? Esse primeiro capítulo adota uma abordagem auto-reflexiva, lidando com questões que estimularam essa pesquisa, assim como com o método de abordagem e com o estilo da escrita, questões essas tão importantes quanto as análises dos filmes e do contexto de suas realizações e recepções. Também propõe um percurso histórico resumido, por entre os documentários mais marcantes desde Cabra marcado para morrer (1984), de Eduardo Coutinho, para melhor circunscrever as mudanças ocorridas desde então e, assim, melhor situar o campo do documentário brasileiro contemporâneo, compreendido nesse estudo entre 1999, ano de Santo forte, que marca retorno ao circuito de salas de exibição de Coutinho, e 2010, período esse no qual se encontram Estamira e A pessoa é para o que nasce.

De onde se emite e se omite o olhar? Para onde é emitido e como se organiza? Uma postura o determina ou por ele é construída? Essas perguntas ecoam desde o início da pesquisa e continuarão ecoar após sua primeira conclusão. Por que estudar o que se escolheu estudar? Como transformar os estudos em um estilo de enfoque e de escrita compatíveis com o olhar de seu autor e com as características dos filmes pesquisados? E como conciliar esse estilo às normas e formatações de um texto acadêmico?

Ao contrário de uma tradição dos estudos de cinema, que em geral partem para uma questão crítica a partir de um afeto positivo pelos filmes (como uma escolha que se

\footnotetext{
${ }^{4}$ Trecho do artigo $O$ ornamento da massa, parte do livro de mesmo nome. São Paulo: Cosac Naify, 2009. O volume original foi organizado pelo próprio autor em 1963, Das ornament der masse: essays, e editado pela Suhrkamp Velag.
} 
impõe à razão pela sensorialidade), essa pesquisa faz movimento contrário, partindo para a crítica a partir de incômodos e resistências a certos documentários contemporâneos e, por extensão, a uma forma de recepção desses documentários e da produção discursiva mais ampla sobre filmar o "outro" (de classe). Esse incômodo em relações a filmes e discursos críticos tem, como razões gerais, duas características recorrentes: um recuo do mundo histórico e social em benefício do mundo particular de personagens, que em alguns casos tendem a transformá-los em seres autônomos e desconectados, e o critério da carisma e da rentabilidade cênica para o outro ser imagem (ser si mesmo na imagem e na banda sonora).

Essas duas características, de forma pouco questionadora nos últimos dez anos, têm sido legitimadas criticamente, talvez em nome, justamente, dessa também questionável operação de dar voz, de dar imagem, de dar espaço no audiovisual para sujeitos quaisquer, em uma espécie de democratização da imagem das pessoas, um programa "invisibilidade zero", no entanto pautado por uma hierarquia e seleção, algo pouco notado e levado em conta nos textos e estudos críticos: o da rentabilidade cênica e do talento para fazer algo, nem que seja, grosso modo, o talento de acontecer diante da câmera (algo a ser desenvolvido no capítulo 3). Não deixa de ser um reflexo desse momento histórico tão performativo, tão incentivador de performances físicas, profissionais e cênicas, tão sedento de espetacularização de anônimos, dando-lhes bem mais dos 15 minutos de celebridade profetizados por Andy Warhol.

Pela lógica do documentário brasileiro contemporâneo, ou pelo menos de boa parte dele, não se trata de todos terem 15 minutos de fama, mas de anônimos potencialmente espetaculares terem um filme inteiro para aparecer. $\mathrm{O}$ documentário não torna seus personagens famosos, no máximo lida com famosos, mas transforma pessoas em personagens, justamente, porque as torna públicas por meio da imagem e da voz. Nesse processo de caça de personagens performáticos ou talentosos, que possam por si só ser um pólo de atração e interesse, principalmente se forem acometidos de perdas e desgraças generalizadas, às quais precisam demonstrar resistência e energia para superar as dificuldades, ganhando imagens de seres persistentes em suas frágeis situações, potentes em suas carências, mesmo se ao fim termine por se concluir que as transformações são impossíveis de serem cumpridas (ao longo do filme). 
"Documentário não é dar a imagem e a palavra do outro, mas tomar dele para nossa realização", afirmou Gabriel Macaro em um debate sobre Avenida Brasília Formosa (2010), na $14^{\text {a }}$ Mostra de Cinema de Tiradentes. A frase tem alguma proximidade com algumas reflexões de Stella Senra e Jean-Claude Bernardet em debates ou cursos realizados nos últimos dez anos. A pesquisadora utiliza uma visão de Massa e poder (CANETTI, 2005), questionadora sobre a situação de pergunta, próxima do interrogatório, sendo por isso vista como invasiva, quando não coercitiva. Já Bernardet, em mais de uma oportunidade, tem questionado a situação de entrevista, sobretudo no anexo da edição atualizada de Cineastas e imagens do povo (BERNARDET, 2003: p. 281-296). Qualquer entrevistado responde a uma pauta do documentarista e muitas vezes o atende, como somos constantemente lembrados nos textos reunidos em Ver e poder (COMOLLI, 2008). Não é preciso ser duramente solicitado, nem ser ex-funcionário do diretor, como acontece em Santiago (2007), de João Moreira Salles.

A potência dos filmes centrais na análise, portanto, não nasce de suas energias estéticas, mas do campo no qual estão inseridos como agentes e como reflexos. O mal estar pode ser estimulante para a reflexão, como nos mostram alguns grandes críticos de arte e de cultura, de Sigmund Kracauer ${ }^{5}$ a Jacques Rivette ${ }^{6}$, desde que, para além da sintomatologia, as situações analisadas sejam mobilizadoras. Para um crítico, mais vale um material nocivo ou abjeto que um medíocre ou gerador de indiferença. Um crítico nasce com uma crise, com o sofrimento, com desejo de reação. E de confronto compreensivo com seu tempo histórico:

O lugar que uma época ocupa no processo histórico pode ser determinado de
modo muito mais pertinente a partir da análise de suas discretas manifestações
de superfície do que dos juízos da época sobre si mesma. Estes, enquanto
expressão de tendências do tempo, não representam um testemunho conclusivo
para a constituição conjunta da época. Aqueles, em razão de sua natureza
inconsciente, garantem um acesso imediato ao conteúdo fundamental do
existente. Inversamente, ao seu conhecimento está ligada sua interpretação. O

\footnotetext{
${ }^{5}$ Seguindo a mesma direção de Kracauer (em vários artigos de $O$ ornamento da massa), acredito que os objetos indesejáveis, sem legitimação, infames, confirmadores de mentalidades predominantes e até abjetos podem nos revelar algo sobre nosso tempo e nosso campo sócio-cultural, tanto ou até mais que as obras canonizáveis e desbravadoras. Para Kracauer, o teatro e o cinema sem qualidade, os grandes espetáculos populares e a literatura só de ambições comerciais, em suas superfícies e estruturas, nos mostram muito das mentalidades dos criadores e de seu público, da sociedade enfim.

${ }^{6}$ Em sua crítica intitulada Da abjeção, publicada em Cahiers du Cinéma, no 120 , edição de junho de 1961, Rivette ataca Kapò (1960), de Gillo Pontecorvo, pelo cineasta não se fazer questões prévias antes de filmar uma tema como os campos de concentração, como se, por incoerência, preguiça ou tolice, tivesse negligenciado uma auto-interrogação sobre suas opções. Retorno a esse texto adiante e à questão da abjeção como ferramenta crítica.
} 
conteúdo fundamental de uma época e os seus impulsos desprezados se iluminam reciprocamente" (KRACAUER, 2009: 91)

\section{Recusa do autor como método}

Nessa introdução, descarto, portanto, alguns recortes (mais presentes nos estudos de cinema acadêmicos ou não). O primeiro deles é a perspectiva autoral consagrada pela crítica francesa dos Cahiers du Cinéma nos anos 50, a "política dos autores"), depois fetichizada e banalizada pelas gerações posteriores de resenhistas e analistas de filmes, que saem à caça de autores precoces ou autores escondidos como se o cinema e sua crítica dependessem menos das obras e mais de seus progenitores. Os autores antes das obras, como diziam alguns dos Cahiers, não está em meu horizonte. Nesse sentido, opto pela visão de autor de A morte do autor (BARTHES, 2004), para quem a autoria se constrói na relação com a obra, não pela biografia ou pelas intenções dos seus realizadores. Embora voltasse sua reflexão para a literatura, Barthes defendia que o autor está no texto, apenas nele, em suas formas de lidar com a linguagem escrita, jamais fora dessa mise en scène da escrita.

Também levo em consideração, ainda nesse campo, as posições de $O$ que é um autor? (FOUCAULT, 2003), sobretudo em suas visão sobre o "função autor", a forma com qual certos textos e discursos circulam, pré moldando em suas recepções pelo significado e pela legitimação das marcas de seus autores. Em meu caso, mais que função autor, trabalho com a "função-personagem", ou, de forma mais ampla, com a "função-documentário", levantando a hipótese de que, na produção de filmes e textos críticos nos últimos dez anos, os personagens ("o outro de classe e cultura") e o próprio segmento documental determinaram, a priori, uma certa forma de recepção e de estratégias de legitimação. Essa função-personagem e essa função-documentário, em grande escala, criou uma blindagem crítica menos indulgente na análise de documentários de personagens, ainda mais quando esses personagens são caracterizados e escolhidos por seus déficits gerais (sociais e orgânicas) e por suas vidas infames (marcadas pelo sofrimento e pela falta, razão das câmeras serem apontadas para eles).

Função-personagem porque o personagem, na tradição de Rousseau em suas Confissões, detém a verdade sobre sua pessoa. Essa voz do testemunho de si e do empirismo legitima a presença dos personagens em quadro, desde que a verdade dele 
mesmo, como já foi colocado acima, seja uma verdade espetacularizável e enfática em sua construção cênica e retórica. Já a função-documentário, por mais suspeitas que haja em torno dela, alimentadas pelos documentários híbridos e ambíguos, ainda resiste como "auto-legítima", em continuidade com uma tradição histórica, porque o documentário carrega, ainda hoje, essa promessa de verdade sobre a realidade.

Estudar filmes de um mesmo diretor, dando-lhe a valoração de autor, contém uma facilidade a ser evitada, contida em um nome próprio que, como uma seta indicativa, de antemão propõe uma lógica associativa entre filmes com existência própria. No caso dessa pesquisa, lido com realizadores de filmografia curta (como Marcos Prado e Roberto Berliner), não legitimados como criadores de mundos próprios, não reconhecidos por estilos individualizados, não consagrados como personalidades criadoras de diegeses personalizadas. Na falta de consagração, do sagrado da criação, só temos a matéria mundana, orgânica, sem transcendência dos cânones. La politique de la mise-en-scène e la politique du personage no lugar da politique des auteurs. Até porque a política dos autores, assim como sua vertente americana de Andrew Sarris (a "teoria doa autores"), parte de escolhas para se eleger quem é ou não artista. E o artista medese, nesses casos, pela régua do talento canonizável.

Nada disso interessa e importa nessa pesquisa. Também não interessa restringir o enfoque apenas aos dois filmes em suas especificidades. O campo a ser relacionado é o do tempo histórico (primeira década do século XXI com suas relações com os 40 anos anteriores - a partir do início dos anos 60 do século XX), mas por dentro de uma cinematografia nacional (no caso, brasileira). Em parte porque mesmo em um mundo de produções transnacionais e globalizadas, inclusive para realizadores latino-americanos, a perspectiva dos cinemas nacionais ainda fazem sentido como abordagem, não apenas pelas aproximações entre escolhas formais, mas também por pertencimento a uma mesma moeda, mesmo idioma, mesma tradição cinematográfica, mesma política de captação de recursos, mesma estrutura de visibilidade dos filmes e mesmo campo de recepção crítica. Há um cinema brasileiro, com seu passado e com seu presente, dotados de particularidades.

Tomei a decisão, porém, de colocar em relação. As particularidades do cinema brasileiro não o colocam em uma cápsula desvinculado do restante do mundo do cinema, embora muitos estudos em seu território possam transmitir a impressão de que 
esse cinema brasileiro está sempre mais vinculado à sua origem do que às suas escolhas cinematográficas, colocando o adjetivo de origem à frente e acima do substantivo em torno do qual trabalhamos na crítica e na academia: o cinema. Dentro desse campo já recortado, o do cinema brasileiro contemporâneo, a opção é pelo documentário, não pela ficção (a qual a cinematografia, até o fim dos anos 80, era mais diretamente associada).

\section{Esboço de um presente}

Essa escolha é justificada por duas razões principais: o aumento quase incomensurável da produção documental nos últimos dez $\operatorname{anos}^{7}$ e os modos de recepção desse fenômeno. Embora não seja exclusiva do Brasil, esse aquecimento da produção é histórico, não apenas fruto da inserção das câmeras de vídeo (mini-DVs com fitas) e numéricas (de cartão de memória digital), assim como dos programas de edição (Avid, Première, Final Cut), com o conseqüente barateamento da produção, mas também por conta de uma inflação de valorização da realidade como matéria-prima estilizável de forma mais direta, com toda a gama de tonalidades distintas com as quais os documentários lidam com isso.

Pode-se detectar esse interesse pela matéria-prima do real na imagem não apenas no documentário, mas também na ficção (brasileira e internacional), assim como na televisão, que expandiu suas câmeras para os amadores da imagem, na captação e na performance, não especialistas e não profissionais, mas com entradas cada vez mais recorrentes nas telas, não apenas via Big Brother e outros reality shows. Essa febre de real, às vezes fetichista, banalizadora e irresponsável, gerou discursos, retóricas entusiasmadas e pensamento crítico, ao menos quando potencializada pelo documentário, que, para além da qualidade estética de filme a filme, tornou-se sinônimo de resistência a um tempo histórico, por outro lado, também marcado por toda sorte de virtualidades e artificialismos.

Esse entusiasmo talvez seja reação ao cinema brasileiro de ficção dos anos $80 \mathrm{e}$ 90, um tanto avesso a lidar com as questões da vida brasileira fora das telas. Daí certa festividade. Sobretudo quando as câmeras apontaram para gente do "povo", abaixo da

\footnotetext{
${ }^{7}$ A produção de documentário de 2000 a 2010 foi, segundo pesquisa (a ser ainda mais precisada) para o catálogo da mostra Cinema Brasileiro Anos 2000 - 10 Questões, superior a XX filmes.
} 
classe média, que assim puderam falar, exporem-se, exibirem talentos e saírem do anonimato, sem serem aprisionados a temas anteriores a suas aparições em tela, a uma tese da qual seriam apenas ilustrações, como se insiste em acusar parte da melhor produção documental dos anos 60, em geral apoiando-se na célebre classificação de Cineastas e imagens do povo (BERNARDET, 2003: p. 15-57): "o modelo sociológico".

O termo, que para as novas geração de estudiosos de cinema, tornou-se palavrão, é questionável, pesando negativamente sobre Viramundo (1964), de Geraldo Sarno, e Maioria absoluta.(1964), de Leon Hirszman, por conta da voz do saber de seus locutores. É preciso relativizar a categoria e colocar os filmes em seus momentos históricos, assim como entender essa transferência de uma visão representativa para uma visão particularizante, avessa à representatividade, que transferiu a voz do documentário para a voz do personagem, assim como transferiu a noção de povo sem nome próprio para nomes próprios sem vínculos com o povo.

Talvez um "remake" atualizado do livro de Bernardet, em 2011, precisava-se ganhar outro título: "Cineastas e personagens sem povo", substituindo o suposto "modelo sociológico" pelo atual" modelo "ego-lógico". Não basta ser personagem com carências, com singularidade e de vidas infames. Para individualizar os homens ordinários (GUIMARÃES, 2005), sem necessariamente individuá-los, o que pressuporia uma relação da consciência da singularidade com o mundo social, é preciso que os personagem sejam dotados de carisma e talentos. Os infames precisam ter potencial de fama para se afirmarem como presenças extraordinárias e enterrarem o ordinário de suas vidas em imagens-performances (deles e das narrativas fílmicas).

Portanto, a pesquisa em questão, dentro do cinema, lida com o contemporâneo do cinema brasileiro. No cinema brasileiro dos últimos dez anos, centra foco no documentário. No documentário recente, aborda aqueles que individualizam personagens, sem tema a priori. E no universo dos documentários individualizados, fecha-se principalmente nos protagonizados por personagens com déficits sociais e orgânicos, genéticos ou adquiridos, que, como em quase toda a produção recente pautada por personagens-indivíduos, lida com os "tipos-solos", dotados de forte carga de performance, de rentabilidade cênica, de carisma e talento, com capacidades para saírem da invisibilidade e do mutismo, de modo a ganharem status de mitos imagéticos do mundo cão. 
A escolha de dois filmes, entre outros possíveis dentro desse recorte, deve-se a uma coincidência, que, por questões teóricas, não parecem casuais apenas, mas também causais, sem se ver nisso nenhuma incoerência (entre casualidade e causalidade). Estamira e A pessoa é para o que nasce estrearam em um mesmo ano, 2006, são documentários de acompanhamento cíclico de suas personagens. Fazem parte de um processo imagético anterior, um ensaio fotográfico em Estamira, um curta em A pessoa é para o que nasce. Ambos têm como protagonistas mulheres que vivem das sobras e dos excessos da sociedade, possuem déficits orgânicos, não se caracterizam por encantos físicos, estão acima dos 50 anos, têm histórias familiares problemáticas, lidam com a câmera como atrizes de si mesmas, envolvidas em sua auto mise en scène (FRANCE, 1999). As mulheres ainda terminam nas águas do mar nos planos finais de cada um dos filmes.

\section{Intervalo 1: o mar}

O mar: imagem mítica do cinema brasileiro, de Limite (1930), de Mario Peixoto, a $O$ descobrimento do Brasil (1936), de Humberto Mauro, de Caiçara (1950), de Adolfo Celi, a Canto do mar (Cavalcanti, 1953), de Deus e o diabo na terra do sol( (Rocha, 1963) a Terra em transe (Rocha, 1967). Tema de reflexões de pelo menos dois autores brasileiros, Ismail Xavier (XAVIER, 2007) e Lucia Nagib (NAGIB, 2006), o mar remete a um jogo de forças: entre utopia e distopia, entre esperança e inviabilidade. Se está em toda a história do cinema mundial, em geral no desfecho de percursos acidentados, como em Os incompreendidos ( 1959), de François Truffaut, e O selvagem da motocicleta (1983), de Francis Ford Coppola, nos interessa destacar sua presença simbólica no cinema brasileiro, também quase sempre nos encerramentos das narrativas, como metáfora de uma abertura para dias melhores, como em Abril despedaçado (2000), de Walter Salles, e Os 12 trabalhos (2007), de Ricardo Elias.

Xavier e Nagib se atêm ao mar como metáfora, como projeto, mais explícito nos três primeiros filmes de Glauber Rocha. Vou me ater a Deus e o diabo na terra do sol, filme no qual, depois do cego profetiza que o sertão vai mar, um destino já dado, temos a mítica sequência final, com Manoel correndo no solo árido, sua esposa em queda pelo caminho, tudo ao som dos versos do profeta cego na voz e na música de Sergio Ricardo. Versos esses adaptados de Os sertões, de Euclides da Cunha, onde a profecia é "o sertão vai virar praia e a praia virará sertão", de autoria incerta, "que constava de pequenos manuscritos apócrifos encontrados em Canudos e transcritos por Euclides. (Idem, p.29). 
Mas Manoel, após a fuga do sertão, chega a utopia do mar? Nagib acredita que, nesse final, haja uma inversão cósmica (Ibidem, p. 35). A autora acredita na concretização da utopia sertaneja ao afirmar que o filme "configura um herói progressista que afinal se liberta das influências retrógradas e anti-republicanas do país" (Ibidem, p.39). Xavier dá margens a certa ambigüidade em sua visão desse desfecho. O vaqueiro Manoel está aberto a ir adiante, disponível para novas perspectivas, mas não há garantias de que tenha alcançado, ou talvez até a alcance apenas no terreno do mito e do imaginário, da utopia.

A imagem da corrida Manoel não veicula propriamente um recado ditenha aldático, uma palavra de ordem definida do tipo que encontramos ao final de um panfleto político. Manoel corre, Rosa o segue até cair. Manoel continua sempre, mas sua movimentação não determina a perspectiva: a imagem evoca que é preciso caminhar, abrir perspectivas (...). Ele não tem um caminho unívoco e distinto a seguir, nada confere direção á sua trajetória. Não aparência imediata, ela é um vôo cego pela caatinga, perdida na extensão uniforme, sem orientação definida. No entanto, Manoel ainda corre em linha reta. E projeta sua corrida para um futuro que permanece opaco e fora do seu alcance (XAVIER, 2007. p.90).

Utopia não se alcança. Desde a formulação de Thomas Moore (1997), utopia é um não lugar, o topos que é bom lugar e nenhum lugar, pela etimologia grega. "Faz parte da utopia sua impossibilidade" (NAGIB, 2006. p 32). Beato Sebastião, em Deus e o diabo na terra do sol, afirma que a ilha não existe, a gente traz ela dentro da alma. "O sertão-mar mítico de Glauber é o sentimento dilacerante desse país utópico que poderia ter sido, mas fadado a não se realizar desde o descobrimento" (Idem, p. 33).

Os mares mencionados nos filmes brasileiros pós-Cinema Novo, como Abril despedaçado, de Salles, Os 12 trabalhos, de Elias, são mares em algum nível simbólicos. Nenhum dos dois jovens protagonistas dos filmes, seja o sertanejo do primeiro do início dos século XX, seja o motoboy urbano, encontrará alguma utopia, mas ao menos eles escapam de um espaço determinante, que os aprisiona em um raio limitado de ação, pouco importa aqui se sertanejo está jurado de morte e acaba de perder o irmão enquanto o motoboy parece ser livre para esse deslocar, mas sofre uma perda justamente porque o deslocamento pela cidade é possível (e interditado). Eles vão para o mar, como Manoel, para escapar de seus ambientes. Não fica claro se irão conseguir.

O mar no final de Estamira e A pessoa é para o que nasce é uma opção ambígua, não exatamente de fuga, porque nada indica que elas romperão com seus espaços (o Jardim Gramacho, na baixada fluminense, e Campina Grande, na Paraíba). O mar, nos dois exemplos, é carregado de um simbolismo já distópico, como prêmio de consolação para percursos de vida que, pelo viés dos documentários, não têm muita chance de reviravolta. Nem o lixão vai virar praia, nem Campina Grande, isso sequer é esboçado no filme. O que importa nos dois desfechos é que as protagonistas se mantêm nas mesmas condições do início das narrativas. 
Em Estamira, a personagem, esquizofrênica, trabalhadora no aterro sanitário, chega ao mar. Por seus delírios megalômanos, acha-se criadora da natureza. Brinca com a água, leva "caixote" de uma onda no raso, mas, nas imagens finais, conversa com o mar furioso. A frase final, sobre o poder da imaginação como produtor de realidade, coloca o filme ao lado dela. Não importa tanto para essa imagem que Estamira permaneça em situação parecida com a do início. Interessa a potência dela nessa permanência e continuidade, em como resiste a si mesmo e ao mundo. O mar deixa de ser lugar para onde foge, portanto, para se tornar elemento do qual se apropria. Ela é a dona do mar. Parece claro que, ao levar a personagem até o mar sem ouvirmos nada dela a respeito desse desejo, o filme parte da consciência simbólica, já entronizada no cinema brasileiro nos 40 anos anteriores. Pode-se até ver Estamira como sertaneja, simbolicamente, menos Manoel e mais profeta, uma forte que resiste, apesar do cenário não ser de promessas, de utopias, mas de uma revolta resignada, de um ressentimento com poder reativo apenas.
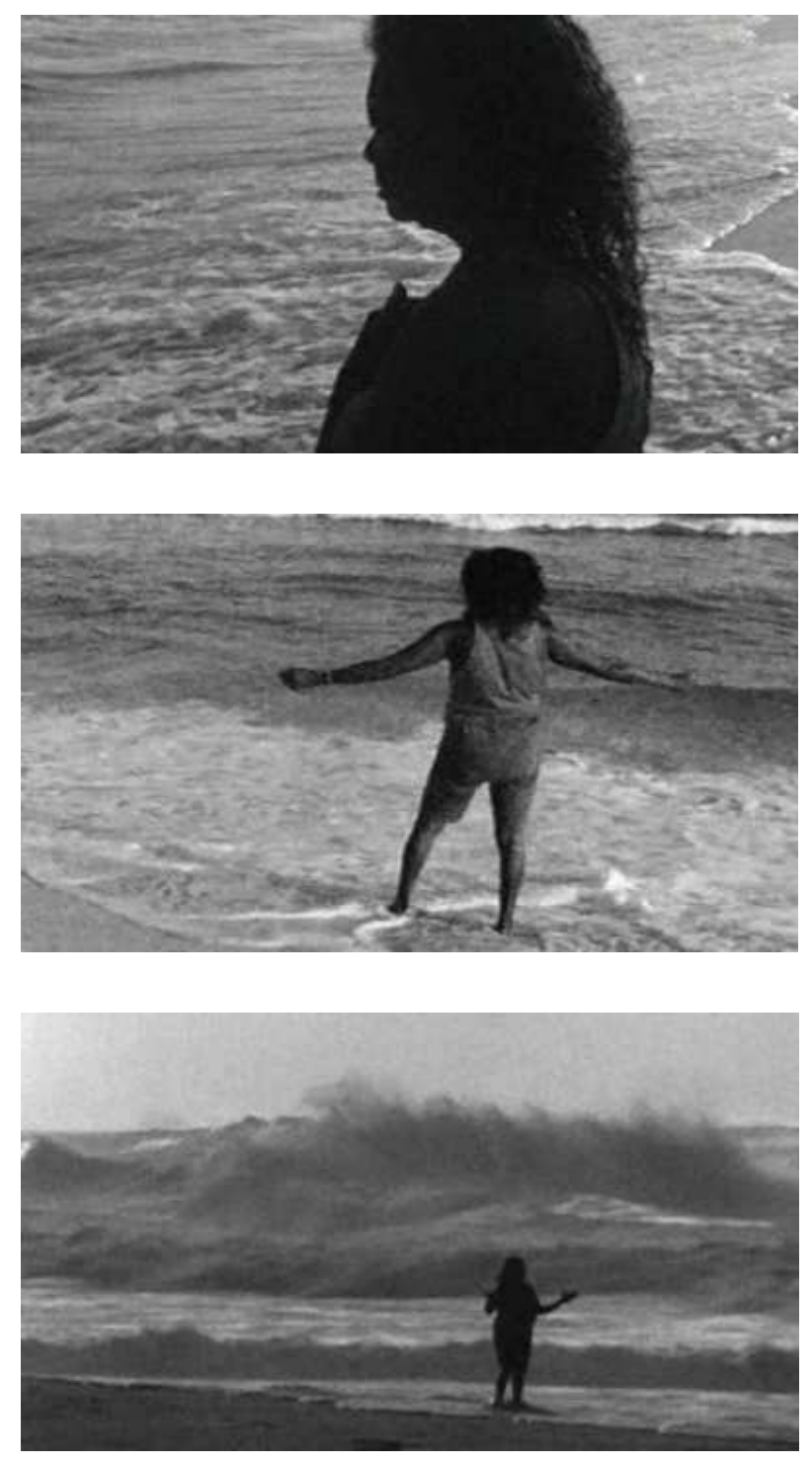


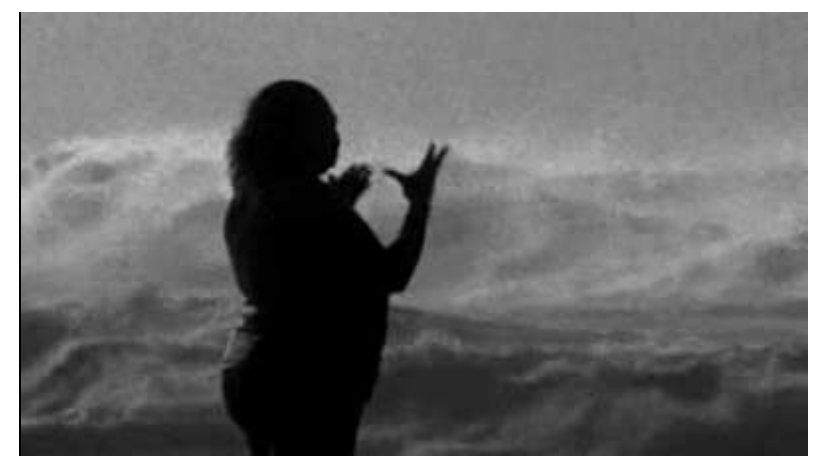

Em A pessoa é para o que nasce, após as três cantoras cegas e midiatizadas voltarem a uma situação de penúria e mendicância, o trio de irmãs aparece no mar. Cantam de forma posada, depois começam a tirar a roupa e ficam nuas ao contato com o mar. Para além das implicações éticas dessa situação, de ignorarmos a forma com que a situação foi solicitada ou aceita pelas irmãs, que se tornam funcionárias do filme (que as ajuda materialmente na vida), é preciso chamar atenção para o que esse contato com o mar, banhado em música de afago aos sentimentos mais catárticos. Elas entram em estado de natureza, de origem, nudez + mar, mas ouvimos suas vozes na cena. Elas dizem que a pessoa é para o que nasce, que Deus planeja tudo, tudo é questão de destino. A distopia não tem a potência de Estamira, mas uma resignação e uma conformação, a rigor muito presentes nas personagens, ao que, em seu desejo de aliar-se a elas, o filme assimila sem aparente questionamento. $O$ mar encerra 0 determinismo, não pela perspectiva social, mas quase metafísica.
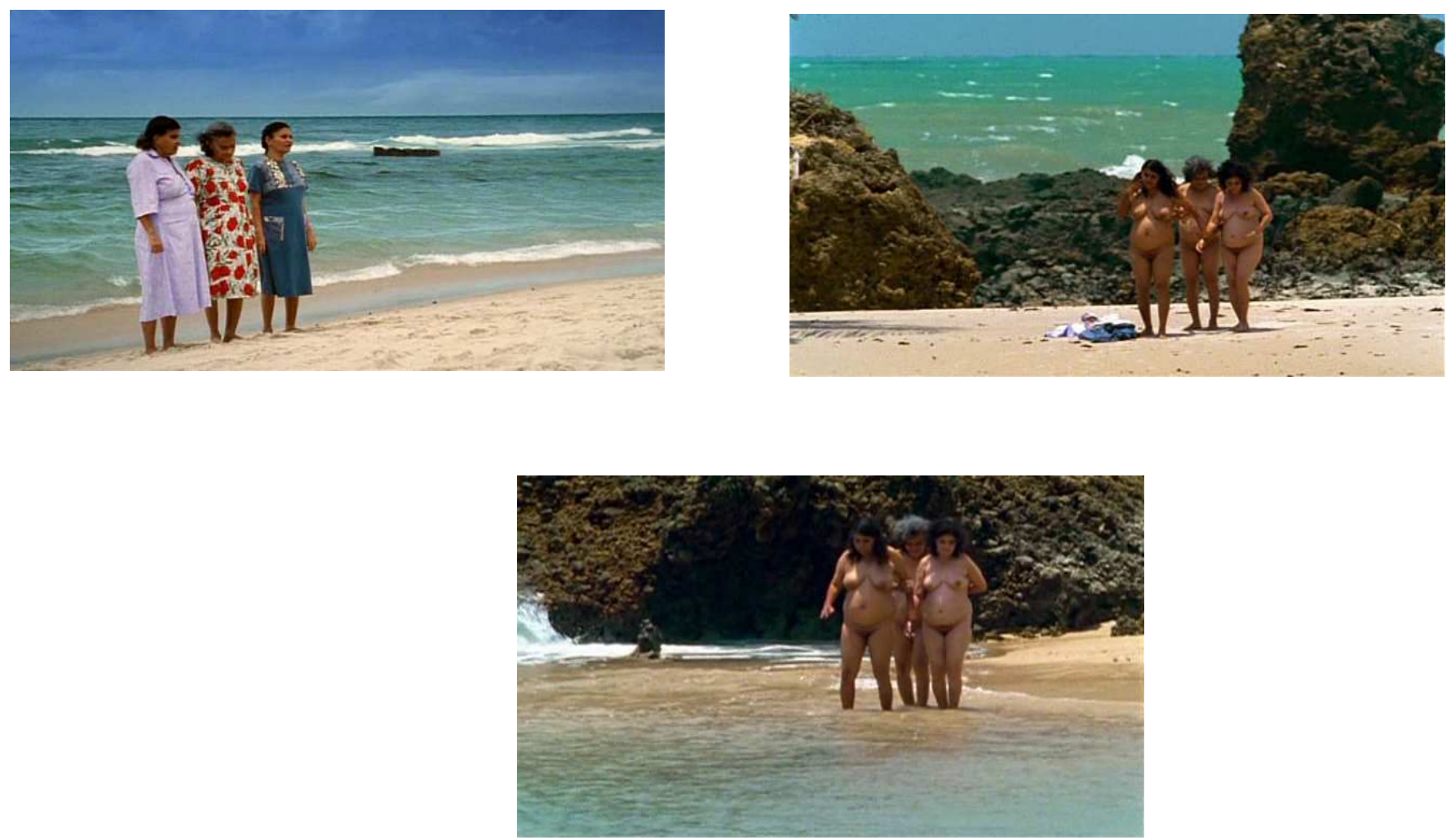


\section{Pequeno mapeamento do documentário brasileiro dos 2000}

Embora já se tenha observado traços do momento contemporâneo no documentário brasileiro, cabe, antes de adentrar a algumas especificidades históricas dessa contemporaneidade dos últimos dez anos e dos próprios filmes centrais para essa pesquisa, abrir um pouco mais a circunscrição de características dessa atualidade. Contamos para dialogar com alguns textos mais abrangentes sobre esse momento e com outros mais voltados para filmes em particular. O mais importante e revelador desse período, porém, é já termos uma produção significativa de reflexão escrita, desenvolvida com os desafios e os riscos do calor da hora, conseqüentemente centrada em hipóteses sem condições de afirmações com distanciamento.

Além de livros e catálogos de mostra e festivais editados nesses últimos dez anos, entre os quais dois livros sobre Eduardo Coutinho (MATTOS, 2003; LINS, 2004), duas publicações são muito importantes para o diálogo aqui proposto: Filmar o real (LINS, MESQUITA, 2008) e Ensaios no Real (MIGLIORIN, 2010). Se este último expressa na variedade de autores e pontos-de-vista a própria multiplicidade de encaminhamentos da realização e da reflexão nos anos 2000, o primeiro tem a proposta de efetuar um panorama sobre tendências e contexto desse documentário brasileiro após o fim da Embrafilme em 1990, com respeito à diversidade de propostas, mas atento a algumas aproximações formais e de enfoque entre os documentários.

Cabe abrir um linha de contextualização histórica para não ignorar algo a ser questionado na relação de jornalistas, críticos e pesquisadores sobre essa fase. Costumase chamá-la, consensualmente, como "retomada". Ela tem data inicial certa (passagem de 1993-1994), mas não uma data final (como quase toda classificação de grupo de filmes em dada sucessão de anos). A produção retornou a passos progressivos nos primeiros quatro anos do período a um certo patamar abortado em 1989. Houve indicação a Oscar de produção estrangeira (O quatrilho, 1995, e Central do Brasil, 1997), Urso de Ouro em Berlim (Central do Brasil) e um terceiro fenômeno comercial (além desses dois), porém sem legitimação externa e quase nenhuma estrutura de distribuição (Carlota Joaquina, 1995).

Não faz sentido, a partir de 1998, insistir em retomar. Estava "retornado", não em condições ideais, também não com o padrão das fases mais altas de venda de 
ingressos (anos 50 e fim dos 70), mas a um estágio anterior, dos anos 80, que continuou progredindo nos anos seguintes, com mais filmes, mais espectadores, uma manutenção sem grandes saltos ou quedas (de $10 \%$ a $15 \%$ ) de taxa de ocupação de mercado interno (com pico acima de $20 \%$ em 2005, ano de Dois filhos de Francisco, em 2005), maior presença nos festivais de primeira linha. O fenômeno Cidade de Deus (2002), de Fernando Meirelles, não é mais da retomada, mas uma outra fase. Por essa fase ainda não ter um nome consensual, como teve a década anterior, não é motivo para mantermos o mesmo nome. Nem uma classificação é preciso, ao menos se não for além da razão cronológica.

O próprio nome retomada é questionável. Retoma-se o que se perdeu, um certo poder e posse, o que estava "tomado". e, em matéria de produção e exibição, o cinema brasileiro sempre foi ocupado (GOMES, 1996), não ocupante, com momentos ciclos de resistência efêmera. Portanto, não se retoma o que não estava tomado. Talvez o termo mais apropriado fosse "retorno", como tenho usado aqui, ao menos, se como é o caso de retomada, a motivação da classificação seja "quantitativa" (número de filmes feitos, lançados e premiados, número de espectadores, número de profissionais na ativa e percentual de ocupação de mercado).

Talvez nunca tenha se debruçado tanto em números na cobertura cinematográfica de imprensa. Os jornalistas especializados em cinema tiveram de lidar com economia (mais que estética). Na falta de um órgão oficial de coleta de dados, surgiu o portal Filme B, que passou a fazer e ainda faz esse papel. Na retomada, o Filme B foi protagonista, tanto quanto os filmes de maior êxitos comercial e artístico. Essa classificação pela economia e não pelas características fílmicas teve, como conseqüência, uma crítica pouco atenta para o conjunto da obra, com suas aproximações estéticas e temáticas dos filmes do período. Uma das raras exceções foram os livros Cinema de novo (ORICCHIO, 2003) e Ensaios sobre uma década (CAETANO, 2006).

Filmar o real (LINS, MESQUITA, 2008: 7-9), em suas primeiras páginas, coloca uma questão: por que o interesse maior pelo documentário no Brasil? As evidências são elencadas: aumento de produção, de festivais especializados, de cursos, de livros, de seminários. Não se trata apenas de fazer documentários, mas de elevá-lo a condição de um campo. O efeito de realidade, constatam as autoras, é mais amplo. Está em toda produção audiovisual (e além dela). 
Desgaste das formas audiovisuais estabelecidas? Tentativas de revitalizar um espectador entediado a quem é preciso oferecer uma dose maior de 'realidade' para quebrar a indiferença? Maneiras de satisfazer o desejo "voyeur" do público de ver sempre mais? Eis questões que nos estimulam a refletir sobre a situação do documentário no Brasil e com as quais, querendo ou não, o cinema documental tem hoje que se defrontar. (Idem: p.8).

Três podem ser os marcos da virada dos 90 para os 2000 (Ibidem. p.14-19): Nós que aqui estamos por vós esperávamos (1999), de Marcelo Masagão; Notícias de uma guerra particular (1999), de João Moreira Salles; e Santo forte (1999), de Eduardo Coutinho. Documentários distintos. Masagão manipula imagens alheias em caráter ensaístico e mescla trechos de ficção com biografias. Moreira Salles não oferece consolo ao espectador, segundo Consuelo Lins e Cláudia Mesquita, "ao destrinchar os mecanismos da violência ligados ao tráfico de drogas no Rio" (Ibidem, p.17), criando paradigma com o qual outros filmes iriam lidar, entre os quais Ônibus 174 (2002) e Tropa de Elite (2007), ambos de José Padiha. Santo forte tem sua importância marcada pelo retorno de Coutinho à tela grande e por inaugurar "um minimalismo estético que será a marca do diretor nos filmes posteriores: sincronismo entre imagem e som, ausência de narração over, de trilha sonora, de imagens de cobertura" (Ibidem.p.18).

Esses três filmes chegam ao mundo em um no qual o Festival É Tudo Verdade teve mais de uma centena de documentários brasileiros inscritos. O efeito novas tecnologias quebrava as hierarquizações no acesso aos meios de produção. É natural que esse processo, historicamente, implique em renovação. Coutinho retorna e permanece nos anos 2000, João Moreira Salles segue bem sucedido percurso na década seguinte (em prosseguimento à sua trajetória nas séries de documentário para a TV), Masagão aparece como um novo nome na cena documental. Outros novos nomes surgiriam nos anos seguintes, como José Padilha, Kiko Goifman, Evaldo Mocarzel, João Jardim, Cao Guimarães, Marilia Rocha e Eryk Rocha, entre tantos outros mais recentes.

Entre os já experientes no início dos 2000 (desde os anos 1960-1970), alguns percursos foram adiante, embora com frequiência e com êxitos distintos, como Silvio Tendler, Vladimir Carvalho, Sylvio Back e Eduardo Escorel; nenhum deles, mesmo nos acertos, à frente dos documentários mais expressivos da última década). Trata-se tanto de um juízo de valor pessoal como de uma constatação menos pessoal, calcada em repercussão, geração de reflexão e relação com o público. Exceção feita a Coutinho, a geração de estreantes dos 1990-2000 deu as cartas. 
Essa renovação de postos teve em Coutinho uma figura emblemática, que faz a ponte entre o documentarismo dos anos 1960-1970-1980 para o dos anos 2000, ou entre o documentário brasileiro moderno e o contemporâneo. Essa passagem é marcada, como desenvolverei um pouco mais no segundo capítulo, por uma recusa do representativo e o privilégio da afirmação de sujeitos singulares (Ibidem, p.20). O documentário moderno é ligado ao Cinema Novo e, pela primeira vez na história do documentário brasileiro, "aborda problemas e experiências das classes populares, rurais e urbanas, nos quais emerge o outro de classe (...)" (Ibidem, p.20).

Outro de classe é conceito usado em Cineastas e imagens do povo (2003) para designar "pobres, desvalidos, excluídos e marginalizados, presença constante em nosso documentário desde então, sob diversos recortes e abordagens" (Ibidem. p.19-20), com as quais os realizadores mantêm uma relação de alteridade. Há disposição de se dar voz ao outro, possibilitado pela sincronia entre som e imagem na captação, algo novo então (anos 60). No entanto, como irei desenvolver com mais atenção, o locutor informativo, explicativo e conclusivo permanece, a exemplo de modalidades mais convencionais, ainda hoje em uso, principalmente na televisão.

No documentário contemporâneo, apesar do uso da narração em alguns documentários específicos, poucos com uma voz não implicada nas experiências do filme (Cidadão Boilesen é exemplo raro), a maioria com o locutor em primeira pessoa (33, Santiago, Diário de uma busca, Solidão e fé), predomina a situação de entrevista. Há ainda investimentos na observação, como Nelson Freire (2004) e Entreatos (2004), de João Moreira Salles, eventualmente com estetização da imagem e da experiência, como em A alma do osso (2004), de Cao Guimarães.

Há ainda as parcerias explícitas entre realizador e personagens no próprio processo de produção, como em O Prisioneiro da grade de ferro - Auto-retratos (2003), de Paulo Sacramento, assim como as parcerias entre profissionais e amadores nos bastidores (não nos filmes) dos documentários do Vídeo das Aldeias e dos chamados filmes de quebrada. E houve os documentários em processo, com algum nível de uma nova reflexividade (com menor potencial de desconstrução), com revelação de dispositivos, nos quais o fracasso pode ser benéfico, como em Extremo sul (2004), de Monica Schmidt, sobre a desistência de uma equipe de escaladores e tensão gerada por isso entre eles e na diretora do filme. 
Também houve os documentários de artistas e outras celebridades históricas, sempre existentes no documentário (brasileiro incluído), que abarcaram de Pelé a Rita Cadillac, de Evandro Teixeira a Glauber Rocha, de Oscar Niemeyer a José Lins do Rego, mas com privilégio dos cantores (Vinicius de Moraes, Tom Zé, Arnaldo Baptista, Titãs, Paralamas do Sucesso, Cartola, Wilson Simonal, Jards Macalé e muitos outros). O filão do personagem sobrenatural, predestinado e obstinado, que supera tudo e fica famoso, reconhecido, é dos mais fortes nos últimos cinco anos.

\section{Intervalo 2: O pós-Cabra}

É preciso fazer um flashback até 1984 para entendermos a passagem dos 1980 para os 2000, com escala nos anos 1990. Se o documentário moderno brasileiro é híbrido, por manter o locutor demonstrativo e informativo em relação com os entrevistados do povo (processo a ser retomado no estudo), um filme específico marca uma virada de dinâmica, Cabra marcado para morrer (1984), de Eduardo Coutinho, conecta algumas forças do cinema de 1964 (colado ao Cinema Novo, às ligas camponesas e ao golpe militar), já com a moderna proposta de estabelecer uma ficção documental com "atores naturais", a uma energia presente em 1984 (do início de uma abertura negociada, de expectativas e alguns acertos de conta pela memória).

O documentário tem alto investimento fílmico calcado em seu próprio processo de produção, com vozes de realizador, personagens e de um locutor a se relacionar, em primeira e terceira pessoas, somadas ao testemunho dos personagens, sempre colocando em relação a história dos indivíduos e a do próprio país entre 1964 e 1984.

Um novo acerto histórico, mesclando encenação com documentos e testemunhos de mulheres torturadas, surge com Que bom te ver viva (1988), de Lucia Murat. As vozes individuais permanecem aliançadas com o contexto histórico e nacional, em parte por conta da experiência da própria diretora sob regime militar, em parte por conta desse clima de acerto de contas pela memória em um momento de atmosfera mais respirável, embora marcado por um (ainda hoje) apagamento apaziguador das tensões, de uma lavagem de roupa imunda junto à sociedade. Portanto, a fissura familiar e cinematográfica de Cabra marcado para morrer, como expressão de fratura social e nacional entre 1964 e 1984 (pelas vozes e pontos-de-vista de suas vítimas), ganha a adição de outros testemunhos também tornadas vítimas, essas não apenas de fissuras, mas de agressões físicas e morais que, inscritos em seus corpos e memórias, amalgamam-se com o processo histórico em andamento. 
Que bom te ver viva marca essa dinâmica associada à noção de docudrama, com divisão entre depoimentos e encenação (com Irene Ravache), talvez para a encenação servir de desparticularização e generalização dos testemunhos individuais. Suas múltiplas vozes de personagens compõem uma única voz, na verdade um único corpo machucado e com a memória das agressões e dos agressores, trazendo para o plano individual e físico um processo político repressivo (o corpo reprimido, comprimido, massacrado) e regressivo (uma política da força física sobre o corpo vulnerável). São os corpos que falam. São as vozes dos corpos. Corpos de mulheres únicas, mas de uma única mulher, personagem de Irene Ravache, que torna o sofrimento de cada uma o sofrimento de todas (e todos).

A década é ainda marcada por Imagens do inconsciente (1983 a 1986), de Leon Hirszman, que já introduz uma das questões mais caras a essa pesquisa, qual seja, a aproximação da câmera do cineasta (ligado à matriz do Cinema Novo) com indivíduos com déficits orgânicos evidentes, mas capazes de superar seus déficits pela sensibilidade. A trilogia é centrada em três internos do hospital psiquiátrico Pedro II, em Engenho de Dentro, no Rio de Janeiro, parceria do cineasta com a doutora Nise da Silveira, que desenvolve atividades terapêuticas e criativas com esquizofrênicos. Lida-se com uma certa metafísica da criação de pessoas (Fernando Diniz, Adelina Gomes e Carlos Pertuis) consideradas apartadas da lógica e da razão.

A trilogia lembrou alguns filmes de grandes diretores para o crítico Ely Azeredo, que, escrevendo em O Globo, em 1987, faz referências ao universo mental de Alain Resnais, a imagem espiritual de Carl T. Dreyer e ao mundo dos sonhos e instintos de Luis Buñuel, pontes essas propiciadas pela fusão entre arte e ciência, pelo "mergulho nas regiões abissais do inconsciente" (AZEREDO, 2009. p87-89). O crítico encara o filme como a afirmação e resistência dos esquizofrênicos pela sensibilidade, elogio ao potencial de grandeza do homem, sem abrir mão da informação objẹtiva e didática, garantida pela presença no texto narrado da doutora Nise.

Hirzsman é o realizador de Maioria absoluta (1964), documentário sobre analfabetismo que, a rigor, trata da exploração dos pobres e de uma política de estagnação e imobilidade. A voz da vítima social em uma situação sem expectativas de melhora. Nenhum indivíduo, apenas vozes do sintoma, da doença social, sem direito a particularizações, apenas a reclamações politizadas em certa medida, a partir da consciência (ainda que resignada) da condição de explorados. Fala-se mais de dinheiro, de renda, de carga horária, pouco sobre analfabetismo. Interesse a estrutura, mais que problemas localizados.

Voltemos aos anos 1980. Não se vê a fissura micro e macro de Cabra marcado para morrer, não as fissuras dos corpos e mentes de Que bom te ver viva, mas a potência do "sub" 
pela subjetividade. Não se trata da voz da vítima de um processo social, mas das imagens das vítimas da natureza, não como reação a uma contingência da qual têm consciência, mas como expressão e afirmação de um olhar próprio. $O$ inconsciente elevado à condição de título coloca a questão da expressão para dentro do indivíduo (a princípio), não como relação interativa entre estímulo interno e externo, mesma postura inicial de Moacir arte bruta (2006), de Walter Carvalho, também sobre pintor com problemas físicos e psíquicos, que já começa com uma epígrafe de Carl Jung sobre a diferença entre pintar as aparências do mundo e pintar o mundo interior.

A procura pela interioridade expressa em cores e formas está em relação com a voz da ciência sensível, a de Nise da Silveira, capaz de chegar a entendimentos e explicações sobre as obras dos três internos, voz de análise e de legitimação. Não é diferente do papel da voz do especialista em Moacir arte bruta, que, além de dar explicações sobre as obras enquanto Moacir desenha, acaba por criar com ele um desenho, também analisado durante a sua própria concepção.

Moacir é tratado nesses momentos como cobaia. Em Imagens do inconsciente, os internos são objetos de estudo. Não é o caso de Estamira, não ao menos como caso internalizado no filme. Não há especialistas a comentar sobre o estado da personagem. Quem faz essas análises e diagnósticos são os filhos, com suas hipóteses para o ódio a Deus e para a imersão da mãe no lixão. Um lixão não apenas literal, mas também metaforizado, como resto e como potência do resto.

A potência em Imagens do inconsciente, vista dentro de uma instituição pública, mas sobre pelo olhar de um indivíduo que faz a diferença dentro das institucionalizações (doutora Nise), não é a do resto social, mas a da interioridade (intocada ou relacional?). Sem querer transformar filmes isolados em retratos de um período ou do cinema em dado período (essa do encaminhamento para uma transição), importa nessas relações perceber como o documentário brasileiro seguia seu caminho, ainda conciliando vozes individuais com vozes analíticas, procurando não presenças em cena, mas discursos baseados tanto em experiências como na consciência e na lógica.

\section{Os anos 1990}

Os anos 1990 foram mais diversificados, apesar de nos primeiros anos da década ainda se lutar contra os efeitos do fim da Embrafilme, com a manutenção de mecanismos isolados de produção, mas muitos filmes interrompidos por falta de verba ou não exibidos por falta de uma estrutura ou ao menos um esquema de distribuição. Entre os críticos atuantes nesse momento, esses anos de ressaca eram chamados de "período da draga", ao menos nas conversas informais. De dentro da draga, porém, surgem reações, no caso, documentários 
reativos, críticos em relação às mentalidades de poder e da sociedade no Brasil, que dão prosseguimento ao acerto de contas pela memória e pelos documentos (e evidências da própria cultura), em dois casos pelas mãos e olhos de diretores já sedimentados no documentarismo: Sylvio Back e Vladimir Carvalho.

Sylvio Back lida com as representações de mitos e de discursos históricos oficiais em Rádio Auriverde. Coloca em relação a participação da Força Expedicionária Brasileira na II Guerra Mundial, sem nenhuma preparo, e a construção da usina siderúrgica de Volta Redonda, parte da política de boa vizinha e de mútua comodidade de Getúlio Vargas com Franklin D. Roosevelt. Um momento de se subir de degrau, ascensão essa da qual a participação na II Guerra seria uma expressão simbólica, mais que militar, algo explorado pelo documentário, que trabalha em cima do patético dessa participação militar trapalhona. Os pracinhas são vistos por Back como parte do Exército de Brancaleone (1965), filme italiano do cânone cômico dirigido por Mario Monicelli.

Há um estímulo a se questionar as verdades sedimentadas por conveniências e discursos legitimados pela ausência de embates contrários a eles. Back torna-se a enunciação da contramão nesse momento, gerando controvérsias amenas e outras menos nos espaços públicos de recepção (a crítica, o jornalismo, os festivais). Não havia personagens, mas um posicionamento, uma postura, um contrafluxo enunciativo. Não é de regime militar que se trata mais, mas de lógica cultural mais ampla, falseadora e perniciosa.

Conterrâneos velhos de querra, de Vladimir Carvalho, não tem o humor corrosivo de Rádio Auriverde, de Back, mas a mesma contundência crítica. Em vez de uma voz do documentário a resignificar os documentos e discursos históricos, temos múltiplas vozes e memórias participantes da construção de uma utopia arquitetônica, Brasília, expressão de uma utopia maior de modernização do país, na virada dos 1950 para os 1960 . Essas vozes em contraste, conflito e em relação no corpo fílmico expõe a falácia da utopia, produtora de uma camada popular rejeitada nessa inserção a partir do isolamento físico. Isolamento pelo controle do corpo e pela distância do espaço utópico, na verdade transformado em mais um espaço de separação e hierarquização social, que joga para longe a mão de obra responsável pela construção da cidade.

A história da utopia de uma espaço utópico em seu projeto, portanto, é colocada em relação à história dos indivíduos implicados, sobretudo a mão de obra nordestina. São os próprios protagonistas que testemunham sobre o processo social, histórico e existencial, no qual parte deles se coloca como vítima indignada e outra parte como proponente de uma visão conformadora. Como em Rádio Auriverde, há uma procura pelo acerto de contas, a partir da memória pessoal e dos documentos, seguindo a mesma direção de Cabra marcado para morrer e Que bom te viver viva, embora com outra delimitação do espaço social. 
Já mais para o final dos 1990, o documentário brasileiro foi marcado por uma contínua inserção comercial e no circuito dos festivais, como Carmem Miranda - banana is my business (1995), de Helena Solberg, No rio das Amazonas (1995), de Ricardo Dias, protagonizado e narrado por Paulo Vanzolini (em seu papel e condição de "pesquisador científico"), O Velho - a história de Luiz Carlos Prestes (1997), de Toni Venturi; e Cineasta da selva (1997) de Aurélio Michilles, sobre um dos pioneiros do cinema brasileiro na Amazônia, Silvino Santos, um empreendedor cinematográfico do ciclo da borracha.

Os filmes lidam com temas e personagens. Em três deles, personagens célebres ou iá legitimados, do passado, que, por meio dos filmes, inserem-se no arquivo vivo do cinema, como preservação de memória. $O$ Velho vê o Brasil do século XX pela perspectiva da esquerda, de um indivíduo existencial e mítico, Prestes, o personagem a conduzir essa história de país, marcado por ações e pela presença simbólica, ambos estimulantes para imaginários, talvez até mais que para ações. Importa o homem em sua biografia, em seus afetos e em sua particularidade, mas tudo isso está fundido ao mundo onde vive. A escolha do personagem já traz grande parte dessa relação entre indivíduo e seu meio. O mito é historicizado, não está acima da História, pois depende dela.

Carmen Miranda também lida com o Brasil, mais centrado no mundo da cultura de massa, nas relações de troca dos símbolos culturais brasileiros e da exploração deles pela indústria cultural dos EUA, em forma sempre de estereótipos (sexo, carnaval, hedonismo), "(...) Não nos iludamos: quando um americano via Carmen, estava vendo não apenas uma cantora exótica, mas a imagem de um pais (ORICCHIO, 2003: 63). Há também uma aproximação com a pessoa de Carmen, com sua intimidade tornada público, com os bastidores de vida por trás das superfícies das imagens e da emissão da voz, mas também sem se perder os laços com o universo social (do trabalho, no caso) e com sua forma de atuação sobre essa singularidade explorada e beneficiada por esse universo.

Mais uma vez temos um olhar na contramão da mitificação e colocando um mito nacional dentro de um processo histórico no qual ele perde um pouco de sua força mobilizadora e ganha um significado de sintoma e vítima. Mais uma vez, por documentos, imagens, memórias e visão pessoal da realizadora temos um acerto de contas com o passado histórico, pautado pela necessidade de se colocar contra as visões hegemônicas e os sensos comuns artificiais. Há pesquisa, análise, um estudo, sem pretensões objetivas, com assumida visão particular.

Muda o tom e as motivações em No rio das Amazonas, filme sem contundência crítica, aberto a observar seu universo e a veicular informações sobre ele. O tema é o espaço (o rio, a Amazônia, a natureza, a população ribeirinha, a cultura local) e o personagem é um quia de conhecimento científico sobre esse espaço, Vanzolini, sem dar espaço para falar de si mesmo 
ou para emitir pontos-de-vista assumidamente subjetivos em sua fala, calcada em uma objetividade de pesquisador. A Amazônia é um mito e um espaço. Mais que tudo, mais que visão crítica, temos visão afirmativa.

Em O cineasta da selva, realizado em co-produção com a TV Cultura, não há, como em No rio das Amazonas, uma contundência crítica, mas uma visão afirmativa. No caso, uma tentativa de inserir Silvino dos Santos no imaginário cultural cinematográfico, sobretudo o relacionado ao período silencioso, em geral ocupado pelos cânones Mario Peixoto e Humberto Mauro. Assim como Que bom te ver viva e Carmen Miranda: banana is my business, há mistura compartimentada, e não fundida, entre a parte mais documental e uma assumida encenação. Também em sintonia com o documentário sobre Carmen Miranda, $O$ cineasta da selva trabalha o mito e o contexto de uma figura portuquesa, que, pelas contingências, torna-se um símbolo nacional, embora mais para pesquisadores e cinematecas que para a mass midia como foi o caso de Carmen.

A Amazônia, porém, como Carmen, é símbolo identitário. Tanto quanto resgatar a obra e se elaborar como biografia de um documentarista, $O$ cineasta da selva trata desse símbolo, não apenas para mitificar, mas para melhor compreendê-lo. Podemos pensar esses documentários dos anos 90 ainda em relação à memória e à simbolização de personagens destacados e de processos históricos conturbados, aplicando o documentário como espaço de preservação e de deslocamento, sempre de modo a entender esses processos e personagem como substâncias de uma História do Brasil, sempre procurando participar da construção constante de uma identidade coletiva, embora a partir na maioria desses casos de identidades e trajetórias individuais.

Mas é no apagar das luzes da década, em parte por conta da produtora Vídeofilmes, com Futebol (1998), de João Moreira Salles e Arthur Fontes, e Notícias de uma guerra particular, de João Moreira Salles, e em maior parte ainda por conta de Santo forte, de Eduardo Coutinho, retorno do cineasta ao circuito comercial depois de iniciativas em vídeo de repercussão mais discretas e fechadas, como Fio da memória, Boca do lixo e Duas semanas no morro nos anos 90. É preciso atentar-se minimamente para cada um desses marcos de fim de década, sobretudo no que cada um tem de transição para a década sequinte.

Futebol é documentário de acompanhamento dividido em três partes quase autônomas, mas complementares pelo fio condutor do futebol. A primeira parte acompanha adolescentes em peneiras e em tentativas de serem exportados. O futebol como sonho material, como ganha-pão, a mobilizar famílias. Existem personagens, mas, antes disso, existe o painel. A soma de particularidades compõe um geral. A segunda parte acompanha Lucio e Iranildo, então revelações com a camisa do Flamengo, em temporada na qual poderiam "vingar". Vão para o banco de reservas. Há uma valorização do acaso e da contingência em 
relação às previsões. A terceira parte centra-se na aposentadoria de Paulo Cesar Caju, imagem da decadência e da prisão a um passado de glórias.

Futebol é um filme um tanto de luto, apoiado em fracassos de seus personagens, naquilo que falta, mais naquilo que está presente. Talvez seja o primeiro dos documentários que, principalmente na década sequinte, viriam a explorar como fracasso como matéria-prima. Também lida com a questão do em processo, do documentário de acompanhamento sem saber onde vai dar certo percurso de personagem, como por exemplo nos chamados "documentários de procura" (33, Passaporte húngaro), na designação de Jean-Claude Bernardet em seu livro sobre Abbas Kiarostami.

Notícias de uma guerra particular substitui o fracasso individual dos jogadores pelo fracasso de uma sociedade atormentada pela violência social ligada ao tráfico de drogas (semente da Tropa de elite, de José Padilha). Cada voz e cada figura ocupam determinado lugar dentro do esquema social e, quando abrem a boca, não o fazem para afirmar identidades, mas apenas suas funções sociais naquela configuração. O policial é policial, o adolescente da boca é adolescente da boca, sem particularidades singularizantes. Talvez esse seja o último grande filme de diagnóstico complexo de um sintoma da doença social, tentando entender a mentalidade e o funcionamento da sociedade, não apenas a partir dos testemunhos, mas também e principalmente de uma relação entre esses testemunhos costurados pela montagem. Sim, um documentário diagnóstico, que coleta evidências e as colocam em perspectiva.

Antes de abordarmos o retorno de Eduardo Coutinho, cabe destacar um outro documentário de 1999. Nós que aqui estamos por vós esperamos, de Marcelo Masagão, que funde ficcões e documentos, memória histórica e produção de micro identidades individuais, mas sempre dentro de um projeto de mostrar o século $\mathrm{XX}$, então em seu epílogo, por uma série de fragmentos cuja associação não produz necessariamente uma visão geral e totalizantes, sequer uma síntese. $O$ corpo do filme talvez expresse como o filme perceba o século do cinema: fragmentado, com rupturas, reinícios, a vida na imagem, como imagem, como narrativas micros.

Sem depoimentos, entrevistas, personagens que se destacam, mas apenas ilustram a idéia geral do filme, o documentário ensaístico de Masaqão consequiu um bom público para a época, reinjetando a ficção então ainda compartimentada nas experiências desde Que bom te ver viva, mas também presentes em Carmen Miranda: banana is my business e O Cineasta da selva, talvez mais próximo do Sylvio Back de Rádio Auriverde em sua ficcionalização, mas sem os mesmos propósitos corrosivos. A obra de Masagão encanta pelo desencanto, não se refere ao Brasil como nos documentários anteriores dos anos 80 e 90, mas a um tempo histórico formalizado em sua narrativa como matéria estética, mais que histórica propriamente. 
Agora sim, Santo forte, de Coutinho. Rio de Janeiro, personagens materialmente carentes, religiões. Os personagens ocupam a cena, falam de si, de seus problemas, crenças e desilusões, mas, além de se afirmarem como indivíduos, são relacionados uns com os outros por pontos em comuns, que, sim, ofertam uma síntese dos depoimentos: a religião não é vista por eles e pelo filme, por meio dos testemunhos, como questão de crença ou devoção a dogmas, mas dentro de uma negociação pragmática, de um pragmatismo da fé. Muitos dos personagens trocam de credo quando a religião a qual estão vinculados não andado certo. Querem promessas cumpridas, pedidos atendidos, principalmente afetivos e materiais. Sincretismo completo.

(...) as pessoas revelam o que há de mais rico e criativo em seus mundos pessoais. A favela, revelada por Coutinho, aparece como um mundo cheio de humanidade, habitada por pessoas extraordinárias. Todo mundo, visto de perto, é um rei. Mas é preciso um olhar fora do comum para perceber essa evidência. (ORICCHIO, 2003: 152)

A pauta do extraordinário dos ordinários, do incomum dos seres comuns, da particularidade para além do tema condicionante, a riqueza diversa e não por acúmulo em um mesmo espaço social, está certo, evidencia-se em Santo forte, embora estivesse já esboçada em Boca do lixo e Duas semanas no morro. Mas somente em Edifício Master essa pauta iria ser consolidada, com o apagamento do edifício em Copacabana como espaço social, afirmando-se no lugar a diversidade completa. Santo forte ainda é um documentário híbrido, nesse sentido, porque lança o encontro com os anônimos como método, a individualização como bandeira, mas ainda está conectado a um tema, a uma síntese, a uma soma de particularidades que, em suas associações, constituem uma visão generalizante sobre parte de uma sociedade.

As carências desses personagens soltam aos olhos e, por mais subjetivas que sejam, essa subjetivação está socializada e encontra ressonâncias fora de si. A década sequinte, mesmo na obra de Coutinho, iria encaminhar para o indivíduo, deixando de lado, progressivamente, as conotações e motivações sociais de suas vivências.

"O filme não pretende revelar a verdade de uma comunidade, mas mostrar o encontro entre duas instâncias sociais rigorosamente diferentes. (...) No fundo, é uma confirmação de Coutinho segundo a qual o documentário é uma negociação de desejos." (Mattos, 2003: 71). O mesmo autor, ainda sobre Santo Forte, vai para além do encontro, quatro parágrafos antes, ao afirmar que "Santo forte é uma espécie de tratado popular sobre religiosidade e misticismo" (Idem: 70). Um encontro entre mundos sociais diferentes que, para além desse encontro presencial, constitui um mosaico sobre religião. Híbrido, insisto.

Se não tivesse havido Santo Forte, Coutinho seria lembrado como o diretor de um grande filme - Cabra marcado para morrer - e por ter realizado alguns poucos vídeos que quase ninquém viu. 'Uma nota de pé de página em um livro 
de cinema. Em 1997, eu não existia mais como cineasta'. Essa afirmação soa no mínimo estranha diante da quase unanimidade em torno da idéia de que Coutinho é hoje o maior documentarista brasileiro. E também do fato de seus filmes serem aclamados antes de serem vistos - o que, diga-se de passagem, não é nada bom para ele nem para os filmes. Um reconhecimento que, em alguns casos, se torna excessivo e acaba fazendo com que seus documentários sejam malvistos e mal conhecidos. Porém, essa é uma situação bastante recente (LINS, 2004: 98).

A religião ainda interessaria documentários vizinhos de Santo forte, como Fé (1999), de Ricardo Dias, O Chamado de Deus (2000), de José Joffily, e Santa Cruz (2000), de João Moreira Salles, mas em nenhum desses a palavra foi tão valorizada (pelos realizadores e pelos críticos, que muitas vezes limitam-se a repetir o discursos dos cineastas com maior articulação verbal sobre suas idéias). Também não há nesses outros os dispositivos de Coutinho, por ele considerados "prisões", a partir do qual constrói os documentários. Esses dispostiivos tendem a colocar limites em vez de abrir o leque. Tendem a partir do mínimo ou chegar a ele.

Dispositivo é um termo que Coutinho começou a usar para se referir a seus procedimentos de filmagem. Em outros momentos, ele chamou a isso de prisão, indicando formas de abordagem de um determinado universo. Para 0 diretor, o crucial em um documentário é a criação de um dispositivo, e não o tema do filme ou a elaboração de um roteiro - o que, aliás, ele se recusa terminantemente a fazer. $O$ dispositivo é criado antes do filme e pode ser: 'Filmar dez anos, filmar só gente de costas, enfim, pode ser um dispositivo ruim, mas é o que importa em um documentário' (LINS, 2004: 101).

Em outros termos, o dispositivo criar um esquema de limitações para o realizador se submeter, dentro desse esquema de segurança, a interferências do acaso, de modo a não poder fazer tudo, sequer ir mais longe do que o dispositivo permite. No caso de Santo forte, o dispositivo é lidar com apenas uma favela, Vila Parque da Cidade, na Gávea, por não ser favela marcada por tráfico ou violência, sem nenhum tipo de sensacionalismo dramático dentro da escolha geográfica, que pudessem pré-significar as experiências relatas pelos entrevistados-personagens.

\section{Dispositivo: disposições para descontrole}

A valorização do dispositivo, conforme afirmei no primeiro capítulo, enquadrase na lógica da não roteirização, deslocamento à "centralidade organizadora da enunciação para um esquema gerador de algum descontrole”, como escrevi no catálogo da mostra "Cinema brasileiro anos 2000 - 10 questões" (2011, p 62). O que mais se descontrola é a instância do autor, da autoria, que se torna compartilhada com as situações em andamento, com os personagens. Esse autor, depois do descontrole, 
recontrola (na montagem). As regras continuam sendo dadas pela instância da narração autoral, apenas de outra forma e com outra dinâmica.

As indefinições e ambigüidades passam a ser valorizadas nesse contexto. Não saber se torna um valor. Cezar Migliorin escreve, no texto introdutório de Ensaios no real (MIGLIORIN, 2010, p.9), que, se diz documentário, não sabe do que está falando, pelo menos não exatamente, problema que considera trunfo. E posição política. Partindo de Giorgio Agamben, autor em alta na discussão do documentário no Brasil, embora não escreva sobre cinema e documentários especificamente, Migliorin afirma que Estados e poderes (em geral) "não sabem agir quando as reivindicações vêm de um lugar sem identidade, ou melhor, os poderes sabem lidar com as reivindicações que partem de lugar definido. Dito de outra maneira, todo poder sabe lidar com o que ele sabe nomear" (Idem).

O ensaio continua com essa proposição de que, sendo assim, o documentário é o nome de uma liberdade no cinema. Valoriza o espaço documental como espaço de invenção e de compartilhamento de imaginários (ou negociação de desejos, nas palavras de Eduardo Coutinho). "O documentário não é o que diz ou mostra o que existe, mas o que inventa a existência com o que existe. (...) Mas, como arte, não lhe interessam apenas suas possibilidades de apresentar ou escrever os sujeitos, mas também suas capacidades produtivas" (Ibidem, p.10).

Esse posicionamento deriva em alguma medida das estratégias de Jean Rouch desde antes do som direto, mas, em vez de solicitar um encontro apenas pela palavra, reivindica o espaço do silêncio. A noção de encontro é defendida, não sem suspeita, não sem cautela. "No lugar da presença do outro, da relação e da imaginação, inseparável do estar junto, o encontro não pode se tornar apenas um desafio de performance?" (Ibidem, p.13). Pode sim. E esse caráter performativo, que discutiremos no capítulo 4, é uma das marcas do contemporâneo, não apenas no documentário e, inclusive, nos próprios processos de dispositivo. Com ou sem controle, visa-se, de alguma forma, o espetáculo, ao menos em muitos dos exemplares atuais. 


\section{Do modelo sociológico ao "egológico"}

Uma das recorrências do documentário brasileiro contemporâneo, desde pelo menos o fím dos anos 90, após o retorno ao circuito comercial de Eduardo Coutinho e sua transformação em paradigma de produção de singularidade, é o processo de individualização a partir da noção de personagem rentável. Se nos documentários de Coutinho esse indivíduo é procurado em um grupo determinado, unido pelo lugar onde moram as pessoas ou por algum outro tipo de ordenamento (religião, trabalho, conexões biográficas), em muitos outros o indivíduo é protagonista, tem status de astro solo e freqüentemente empresta o nome ao título do filme.

Uma das procuras por boa parte desses documentários de personagens únicos (ou quase) é pelo indivíduo capaz de expor rastros e vestígios de potência não representativa, mesmo em situações de déficit explícito, por meio de algum talento e diferenciações possíveis de serem expressos em imagens e sons. A individualização é buscada no carisma e na performance, no alto rendimento cênico. Por estar comprometida com a necessidade de show em alguma medida, é desconectada de seu entorno. A subjetividade encontrada tem frágil relação com o mundo histórico e social.

O ponto de partida para nossa reflexão é relacional e histórico. Se parte dessa rentabilidade cênica egológica se dá pela voz dos personagens, não necessariamente em sincronia com as presenças de fala (uso do som direto da imagem), proponho um cotejo com o uso das vozes dos anos 60, período no qual são realizados os primeiros documentários brasileiros com som direto. Por que esse marco? Porque o som direto como usado no documentário brasileiro inicialmente nos permite ouvir as falas de grupos de pessoas anônimas, do povo, que pode nos informar sobre suas dificuldades, expondo as rachaduras do Brasil, com comentários de narradores com senso de indignação e justiça. Alguns desses documentários foram analisados por Jean-Claude Bernardet em Cineastas e as imagens do povo.

Bernardet considera parte deles como constituintes de um "modelo sociológico" de documentário, com um olhar e um ouvido para as pessoas a partir de uma tese nas quais elas são utilizáveis (BERNARDET, 2003. P. 15-68). Tenho especial interesse nos casos de Maioria Absoluta (1964), de Leon Hirzsman, e Viramundo (1965), de Geraldo Sarno, que lidam com traços do subdesenvolvimento brasileiro, aliando vozes internas a 
uma voz de comentário. O modelo dos dois filmes centrais para a discussão, Estamira e A pessoa é para o que nasce, centrados em indivíduos também socialmente deficitários, é definido no projeto como "modelo ego-lógico".

No "modelo sociológico", vozes e imagens das pessoas comuns eram colocadas em relação a outras pessoas comuns, sem investimento em subjetividade e biografia daqueles corpos com fala. O corpo coletivo, não o individual, estava em pauta. Irei me deter um pouco nessa classificação e nos filmes com as quais lida. Bernardet qualifica as vozes dos filmes, a começar por Viramundo, o primeiro a ser analisado, para procurar um sistema de relações entre elas.

\begin{abstract}
Os entrevistados só falam quando perguntados. O entrevistador, que não aparece na tela, a não ser uma ou outra vez, de costas, em 'amorce', lhes faz perguntas sobre as suas condições de vida e de trabalho, e as respostas limitam-se ao perguntado. (...) Eles são a voz da experiência. Falam só de suas experiências, nunca generalizam, nunca tiram conclusões. Ou porque não sabem, ou porque não querem, ou porque nada lhes é perguntado nesse sentido. Se, por acaso, um operário generaliza, é para dizer besteira por exemplo, que os nossos irmãos do Norte só pensam em matar e que o pessoal do Sul gosta de trabalhar dez, dozes horas por dia. É apenas um ponto de vista que, enquanto tal, fica desqualificado como generalização. Não podemos levar a sério o conteúdo dessa afirmação, podemos apenas tomá-la como um dado sobre quem a fez. Ao emitir sua visão, quem fala, fala de si, e o que diz continua sendo um dado da experiência imediata (Idem, p. 15-16)
\end{abstract}

Nessas primeiras duas páginas do ensaio sobre Viramundo, Bernardet parece cobrar do documentário que as pessoas falem generalizações, para além das experiências empíricas, mas veta uma das generalizações, considerada pouco séria, talvez porque não concorde com ela politicamente. Ou seja, a única generalização aceitável, quando alguém a faz, é aquela já legitimada anteriormente. Parece um tanto óbvio que, ao generalizar sobre os nordestinos, o nordestino em questão fala por si, mas também fala por muitos de igual visão, nordestinos ou não. Esse é um dos momentos, aliás, mais fortes das falas, justamente porque é uma fala de dentro do universo dos nordestinos, mas emitida por alguém que ascendeu economicamente em São Paulo, procurando apagar sua origem e se inserir na auto-paulistanidade construída.

Essa fala coloca a questão de classe acima da questão de origem. Não é a origem nordestina que está em jogo, mas a associação do Nordeste e dos nordestinos com violência, ignorância e pobreza o que o entrevistado tenta explicitar na fala como algo distante da vivência dele, que, com seu suor, conseguiu superar o estágio do subdesenvolvimento. Não é uma fala que expresse uma tese (do filme, pelo menos), no 
máximo é tese do entrevistado. Se está mantida na montagem é porque difere de todas as demais falas, divididas entre aqueles que acham melhor a mudança para São Paulo, os que querem voltar para sua terra natal e os que, apesar de esperanças de melhorar de vida ainda, não conseguem subir os degraus sociais. A fala reprovada por Bernardet, questionável que seja, é a única que sai de certa previsibilidade, por sua vez menos um problema do documentário, talvez mais da realidade a qual ele se refere.

Bernardet destaca que a voz do locutor, essa voz sem corpo na imagem, jamais fala de si, mas apenas de fora, em terceira pessoa, sobre os nordestinos. "É voz do saber, de um saber generalizante que não encontra sua origem na experiência, mas no estudo de tipo sociológico; ele dissolve o indivíduo na estatística e diz dos entrevistados coisas que eles não sabem a seu próprio respeito" (Ibidem, p.17). É preciso relativizar. Os entrevistados não mostram ignorar sua situação. Apenas são chamados a falar das experiências próprias com o trabalho em São Paulo. Também o locutor não dissolve os entrevistados nas estatísticas. Há espaço para cada um ali contar um pouco das razões de seu deslocamento e de suas condições de vida. É um tanto injusto com o filme esperar, como aparentemente se cobra no texto, que a voz do locutor seja equiparada a dos entrevistados. São vozes com funções diferentes.

Também é um equívoco afirmar que "o que informa o espectador sobre o real é o locutor, pois dos entrevistados só obtemos uma história individual e fragmentada pelo menos quando se concebe o real como construção abstrata e abrangente" (Ibidem). Em primeiro lugar, o locutor pode falar com abrangência, jamais com abstração. Lida com questões concretas, porém, sua função é menos de informar, para além das estatísticas iniciais, e mais de estabelecer sínteses e diagnósticos sobre o real. A experiência real, ao contrário do que afirma Bernardet, está com os entrevistados.

$\mathrm{O}$ autor insiste em sua recusa à fala do locutor ao afirmar que essa voz usa os entrevistados como amostragem exemplificadora, que os entrevistados são apenas a matéria prima do discurso fílmico, a prova de veracidade da fala do filme. No entanto, ainda segundo Bernardet, os entrevistados terão de "se encaixar no universo delimitado pela fala do locutor, caso contrário nem a fala do locutor seria a interpretação do real, nem o real - via amostragem - conseguiria autenticá-los" (Ibidem, p.19). 
Proponho uma reavaliação dessa suposição de que a fala do locutor está a frente das falas das entrevistas. Por que ela é anterior, como se estivesse pronta, a espera de confirmações? Por que ela não pode ser considerada como uma fala a partir das entrevistas, complementares, aliado delas, como uma costura para os fragmentos individuais? Parece também exagero retórico afirmar que nenhuma pergunta fora da tese do locutor tem lugar, porque, afinal, as perguntas seguem o interesse do realizador por um tema específico, não particular, qual seja, a problemática social decorrente e motivadora da imigração. Qual o sentido, em um filme com esse projeto, de se falar de outras coisas? É colocar um programa de cinema antes do cinema.

\section{Intervalo 3 - identidades}

Em Viramundo, não há identidades propriamente, mas presenças representativas por suas experiências e pelo relato de vida. Ninguém tem nome e história particular, para além da relação com o trabalho e com o dinheiro, diferença entre uns e outros. Em $A$ invenção de si, Jean-Claude Kaufmann tem consciência de que a identidade é forma de controle, com tantos documentos e reconhecimentos oficiais da pessoa física, tantos números, mas também lembra que, sem uma identidade, em vez de liberdade completa para se ser quem quiser (como em filmes de protagonistas que perdem a memória para se reinventar), pode-se deixar de existir socialmente.

Kaufmann lembra, contudo, que, embora documentos sempre tenham existido como forma de controle e identificação, a identidade do sujeito como auto-identificação é nova, um fenômeno mais associado ao século XX, quando se "tornou para a opinião pública o caráter de subtaneidade, pelas formas de emergência do conceito, próximas da geração espontânea" (KAUFMAN, 2004. p. 31). Nos últimos anos do século, ainda segundo o autor, a identidade se tornou uma linguagem.

Em 14 de fevereiro de 2003, um grupo minoritário do Tribunal Europeu dos Direitos Humanos invocou o direito universal à identidade: "Estamos firmemente convictos de que o direito à identidade, como condição essencial do direito a autonomia (grifo meu), faz parte do núcleo dentro do direito ao respeito da vida". ${ }^{8}$ Kaufman observa que o direito à autonomia, na verdade uma obrigação, quase uma dívida da vida com o indivíduo e do indivíduo consigo mesmo e com a sociedade, aumenta o sofrimento real e nada simbólico daqueles que, desde logo, "já não estão simplesmente à procura de informações importantes que lhes são

\footnotetext{
${ }^{8}$ Citado em KAUFMAN, 2004. p.32
} 
escondidas, mas daquilo que Ihes pode fornecer os significados essenciais, condenando-os a serem meros fantasmas sem essa 'identidade' de que são privados" (Idem, p.33).

Se levamos em consideração a relação de Migliorin, a partir de Agamben, que o não nomeado está livre do controle, então a identidade, mesmo se transformada em individuação no documentário, torna-se uma limitação para o sujeito. No entanto, nem tudo é documento de identificação, assim como nem tudo se resolve pela subjetivação. Kaufman pergunta se seria possível passar por cima da biografia dos indivíduos para eles se auto-inventarem? (Ibidem, p.37). Eles deixam de sofrer com a concretude de suas vidas?

Em recente fala no programa Café Filosófico, exibido na TV Cultura enquanto continuo mexendo no texto por dentro, Renato Janine Ribeiro afirmou que, nesse momento de valorização de identidades individuais, tanto quanto de grupos, acaba por se criar um espaço de competição de "eus" e "nós" contra "nós" (no caso dos eus) e contra "eles" (no caso de nós). A inflamação do indivíduo, individuado ou não, resulta em vaidades, conseqüentemente, em rivalidades por reconhecimento. $O$ que se sacrifica, nesse processo, é a intimidade. $O$ particular, o que se preserva do olhar público, no nosso caso, o que não se filma e não se deixa filmar.

Por que filmar indivíduos para afirmar indivíduos individuados ou performados? Chamo de volta Kaufman: "A identidade não é apenas uma questão pessoal e privada, ela redefine o conjunto da questão social” (Ibidem, p.75). Ele chama atenção para o desequilíbrio entre discursos generosos, satisfação com a solidariedade e o desequilíbrio entre os possuidores e os sem quase nada. Em última instância, é no que insisto, valorizar o individual, sobretudo no documentário, é diminuir o espaço das relações entre indivíduos dentro dessa certa conformação acima deles, conformação essa potencialmente produtora de e mal estares palpáveis (não psicológicos ou de auto-estima apenas). Potencializar falas e presenças de "eus" não éuma forma de conveniência política e de recuo da indignação?

Minha hipótese, no momento, é afirmativa. O documentário brasileiro está perdendo a força como superfície verbal e visual de reação e de indignação, atenuando as relações pela montagem (da qual a defesa do indivíduo e da individuação desconfia por ser possível redutora dos sujeitos ao buscar relações entre planos), valorizando excessivamente o valor em si da duração dos takes e a revelação de algo minimamente surpreendentes inscrito nessa duração, em geral manifestado, como coloca César Guimarães, pelas mudanças na expressão facial. Quando Bernardet questiona Viramundo, pelo caminho adotado e seguido por tantos, está reivindicando esse espaço para o sujeito e a implicação do filme com o sujeito, a posta em cena do locutor e do diretor, como se apenas isso fosse alterar a condição social denunciada.

$$
* * *
$$


Embora relativize parcialmente, Bernardet termina o ensaio sobre Viramundo justapondo a figura do empresário (confrontado pelo diretor no filme) e do locutor (extensão do diretor), por ambos tratarem os operários nordestinos como "objetos". É claro para quem não tenha posições prévias em relações aos filmes que locutor e entrevistador estão ao lado dos nordestinos, solidários com eles, a procura de uma denúncia e de um entendimento para suas situações, ao passo que o empresário, quando entrevistado, mostra completa indiferença com o lado humano e social da situação, preocupado apenas com o pragmatismo da eficiência.

Não se trata de opinião, mas de evidências (sonoras e visuais). Em primeiro lugar, antes de indivíduos, Viramundo procura o conjunto, assim como a condição de classe. Tomemos como exemplo essa entrevista com o empresário em sua primeira aparição. O plano começa na janela de escritório e se move lentamente até enquadrar em plano aberto, o mais aberto nas entrevistas, um homem de camisa branca e gravata sentada atrás da mesa, com quadro acima e livros atrás. Ele começa a falar de forma dura e decorada, sem autenticidade, sua visão indefinida (observa-se) sobre especificidades do nordestino (são desconfiados, não se adaptam). Fala quase gaguejando. Por que essa distância para filmar uma única pessoa? Porque o mais importante é esse ambiente contrastado com o restante. A própria mise en scène determina no corpo do filme sua visão e seu posicionamento.

Voltamos minutos a frente ao empresário já mostrado. Enquadrado mais de perto, com frontalidade inexiste na maneira de filmar o povo, como se fosse um confronto olho no olho. Uma voz de fora de quadro inicia uma pergunta assim: "Senhor empresário!”. Reparemos que, no fim do plano anterior, falava-se do inquilino que iria expulsar o operário sem emprego. O empresário entra como proprietário, nessa relação efetuada pelo corte, cmo instância pessoal de poder. A pergunta aborda a mão de obra não qualificada. O empresário confirma essa precariedade de formação.

Pode-se até dizer que Viramundo, em nome da solidariedade com as vítimas da estrutura social na qual não encontram realização, investe em maniqueísmo de classe, sem nenhum tipo de entendimento mais complexo ou relativo, mas é apressado e muito esquemático acusá-lo de transformar seres sociais em objetos, ainda mais da mesma natureza do objeto para o empresário. O que não interessa ao filme, concordo, é a subjetivação dos entrevistados, sua transformação em nomes próprios, com 
singularidades e intimidades postas em público. O que vem a público é apenas o que a experiência em fala daquelas pessoas tem a ver com a esfera coletiva.

A mesma crítica à locução retorna na análise de Maioria Absoluta (1964). Outra voz do saber, mais redundante em sua exposição crítica, em sua denúncia, mas menos distante se comparada a de Viramundo, ao menos para Bernardet (Ibidem, p.40-41). Menos distante porque o locutor se coloca em termos pronominais, fala tu, nós, evidencia a diferença de classe e a condição de outro dos entrevistados. Há o lugar social do filme, do espectador e dos entrevistados. Inicialmente vemos e ouvimos as falas e os rostos da classe média carioca, com opiniões não exatamente exemplares e sem consciência social mais ampla (similares ao do nordestino elitista e paulistanizado de Viramundo), mas com consciência de seu lugar e do lugar do outro. Depois, a voz e o drama desse outro, analfabeto, maioria absoluta, sintoma da desigualdade crônica.

Há um espírito distópico nesse filme iniciado antes do golpe e encerrado depois. Essa falta de perspectivas transformadoras, em tensão com a indignação diante dos efeitos da estrutura social, motiva o questionamento de Bernardet. Ele considera locução dedo em riste do locutor um estímulo à culpabilidade da elite brasileira. "Eis os homens cujos trabalhos você usurpa e que não têm nada, eles olham você olhos nos olhos, você vai agüentar esse olhar, aí sentado na sua poltrona?” (Ibidem, p.42).

O autor pergunta qual é a possibilidade de ação diante do chamado do filme? E conclui que o filme não dá a saída, não vislumbra canais políticos, com o risco de um voluntarismo deslanchado pelo escândalo social. Uma denúncia sensacionalista, enfim. No fim de Maioria Absoluta, o locutor conclui com efeito retórico, sim, mas também com consciência do comodismo das elites: "O filme acaba aqui. Lá fora, a tua vida, como a destes homens, continua". Trata-se de uma toalha jogada ou uma conclusão cruel em seu realismo? É importante notar que o filme não é um programa de governo, sequer um projeto com todas as linhas de ação de transformação social, mas um filme reativo, que lida com seu mundo a partir da recusa e da denúncia das mentalidades e das situações concretas de pessoas no limite da dignidade cívica.

Mais uma vez, não há individualidades, apenas posições sociais. Como em Viramundo, importa o coletivo. Voltemos um pouco ao filme de Geraldo Sarno. Sua disposição de lidar com o conjunto está na forma de filmar. Isso está explicitado nas 
primeiras imagens na estação do trem, de grupos de pessoas com malas, e nas primeiras entrevistas, sempre com homens lado a lado. Se há alguma possibilidade de relações com seus rostos, roupas e presenças, quando se move a câmera a diferença entre eles só salienta a homogeneidade. Podem ser distintos, mas fazem parte de um mesmo grupo.

Em outro momento, um entrevistado agora fala, de semi-perfil, olhando para a esquerda, que "o salário não dá". Fala da experiência na cidade. Não pode comprar calça e sapatos bons. Diz que fala por ele, não pelos outros. Uma voz confirma o que o anterior disse, colocando o caso do outro na condição de caso geral. Não vemos o rosto de quem fala pela primeira vez. Vemos a imagem de um operário de capacete trabalhando, sem sabermos se é dele a voz. Ao desconectar voz e imagem, expande a situação, pois a voz fala para além dela, fala por aquele mostrado a nós. Generaliza. Operação de montagem, mas em sintonia com a fala. Outra imagem de outros operários, o que salienta esse efeito de expansão da fala. A voz continua falando do que o salário pode comprar e do que não pode adquirir.

No atual momento do documentário brasileiro, o coletivo está fora do individual e, quando há descolamento aparente do indivíduo, é para retornar a ele. São os casos de Estamira, de Marcos Prado, e A Pessoa é para o que nasce, de Roberto Berliner, ambos protagonizados por pessoas com graus distintos de deficiência (déficit de eficiência), mas eficientes em suas presenças como personagens de documentário, rentáveis para os realizadores. No entanto, se rendem para a câmera, vivenciam na visibilidade, em alguma medida, eles trabalham para os diretores. São sua matéria prima e seus funcionários.

Essa tem sido uma questão fortemente brasileira. O documentário europeu, asiático e norte-americano, muito longe da perspectiva dos personagens, a não ser quando esse personagem é o próprio autor, como Alain Cavalier, Chantal Ackerman e Agnès Varda, que, mesmo assim, jamais rompem relação entre subjetivo e pessoal. Por mais que vivamos a inflação do eu, a competição entre vaidades e a caça a singularidades, o documentário em outros países, a começar pelos latino-americanos, jamais abrem mão de tocar o em comum gerador de sofrimentos 


\section{Intervalo 4: o som direto nos anos 1960}

A individualização rentável e produtiva para o documentarista e para o espectador, colocado diante de homens e mulheres shows, tem um processo histórico iniciado com o som direto e sincrônico. Por isso, a opção por recuar 45 anos, de modo a perceber como, no início das falas sincronizadas com a imagem no Brasil, o uso da voz era diferente. Importante atentar-se para o fato de que, em 1964-1965, o clima era de insegurança ou de ameaça. A deposição de João Goulart e a entrada de Castelo Branco após o golpe militar colocavam a questão das vozes em uma circunstância política particular. Os cineastas, em geral de classe média, intelectuais e de esquerda, precisavam falar por quem não tinha voz, mesmo sem ter soluções para esses a quem ouviam e por quem denunciavam.

Esse contexto político é fundamental para entendermos porque o som direto no Brasil não foi utilizado em moldes próximos aos de Jean Rouch e Robert Drew, para ficarmos em dois paradigmas do modelo interativo-participativo e do observacional (NICHOLS, 1991). Em vez da voz do outro assumir o carro chefe, provocada ou não pela circunstância de filmagem, dividiuse o campo sonoro entre voz da cena e voz do filme, que tornava clara suas posições e enunciações.

Se ainda hoje há a presença de locutores em documentários, eles em geral falam em primeira pessoa ou são vozes de documentários para televisão, seguidores do mundo expositivo consagrado pela pedagogia social de John Grierson. O estigma em torno do que se chamou de modelo sociológico, com o relançamento do livro de Bernardet, bateu em cheio no novo momento do documentário. Nada de explicações, denúncias ou co-relações, na maioria dos casos. Apenas a experiência única, individual, rica no que tem de singular, mas também um tanto ou muito desconectada do mundo.

\section{Intervalo 5: duas conversas sobre documentário}

1) Em uma sala de aula de um curso de documentário, com parte teórica e prática, uma aluna pergunta se, caso encontre um personagem "figura", que seja carismático e expansivo, com uma história de vida intensa, pode fazer o filme todo com ele. O professor pergunta como ela pensa em filmá-lo (gravá-lo em tempos de audiovisual). Ela não pensa sequer um segundo: "Farei uma entrevista com ele em seus lugares preferidos". Essa é a mentalidade bastante generalizada: encontre um personagem com potencialmente de rendimento, ligue a câmera e faça perguntas para ter um documentário

2) Um estudante de cinema em fim de doutorado afirma a outro estudante de cinema que o problema do documentário brasileiro é sempre querer lidar com o social. Insiste que, se 
não quisessem mudar o país, seriam melhores. Questionado pelo outro estudante sobre os filmes que tinha em mente ao fazer essa afirmação, teve como resposta primeiro um silêncio, depois a reposta mais à mão: Ônibus 174. Nova pergunta como reação: você acha que Ônibus 74 quer mudar o país? Novo silêncio. É assim quase sempre. Não importa a realidade filme a filme, mesmo para quem estuda cinema, mas um certo senso comum tornado verdade.

A individualização desses homens e mulheres chamados de comuns, ordinários ou infames não pode ser confundida com a noção de individuação (a partir de Jung), que leva em consideração os aspectos comuns de toda diferenciação do singular. Individuar é encontrar a singularidade em um campo social e cultural comum e contextualizado. Não se trata de romper com o mundo social e histórico, mas se afirmar como um eu particular nele, muitas vezes por meio dos desejos, da imaginação, dos gestos não capturados pelos códigos de conduta, pela forma de falar não formatada pela forma da fala esperada de cada um. Uma forma de resistência à codificação do indivíduo, que, com duração do plano e atenção da câmera para seus gestos menores e para sua presença nos ambientes, conseguiria se singularizar de modo a não ser capturado por determinações e reducionismos.

Embora possamos levar em conta uma individualização e uma individuação de ilustres, como os artistas e outros famosos, vamos nos deter nos anônimos retirados dos anonimatos pela câmera e pela projeção. Novamente, os outros de classe, antes povo, hoje personagem em potencial. Quando esse outro é menos personagem e mais povo tende-se a mostrá-lo em uma perspectiva ligada ao miserabilismo e à criminalização, em parte fruto, segundo Fernão Ramos, não de uma acusação dos realizadores, mas de suas consciências culpadas.

"O burguês e sua má consciência, violenta e exasperada", talvez seja um bom título para começarmos uma análise do cinema brasileiro dos últimos 15 anos. Venho trabalhando com o conceito de narcisismo às avessas para definir essa condição" (RAMOS, 2008, p.206). O autor vê um movimento auto-flagelatório na representação do outro, o que cria uma distância, seja pelo deslumbramento ou pela agressividade, reflexos das próprias distâncias sociais e econômicas entre quem filma e é filmado. 
Embora fale das condições precárias de sobrevivência dos seres em imagem, mostrados com crueza e intensidade, Ramos valoriza a contingência de alta violência , exibida em documentários como Notícias de uma guerra particular, de João Moreira Salles, O Rap do pequeno príncipe contra as almas sebosas, de Paulo Caldas e Marcelo Luna, Á margem do concreto, de Evaldo Mocarzel, Ônibus 174, de José Padilha, Falcão: meninos do tráfico, de MV Bill e Celso Athayde.

Podemos incluir Estamira e A pessoa é para o que nasce nessa linhagem da ênfase na vida sob riscos, mas, por serem centrados em indivíduos e não em questões sociais mais amplas, ao contrário dos demais documentários mencionados por Ramos, essa violência é atenuada pela força da presença da persona. O comum das personagens desses documentários, panorâmicos ou individualizantes, é o incomum com alta carga de exotismo, prato cheio para olhares curiosos pelas bizarrices e pelo mundo cão. Ter uma vida de des-graças para expor é aquecimento para os famintos pela miserabilidade do outro como forma muitas vezes de se sentir mais confortável.

Tanto em Estamira como em A pessoa é para o que nasce há estupros, abandonos das mulheres pelos homens, evidências de carências materiais, embora, por serem pessoas de personalidades diferentes, isso coloca uma distância entre os filmes. Estamira é uma rebelde, ressentida, apocalíptica, brigada com Deus, uma messiânica sem seguidores. Maroca, Poroca e Indaia são religiosas, resignadas, aceitam as coisas como são. Estamira não pensa em fama ou reconhecimento. Sente-se poderosa. Também não fala em dinheiro, assim como dinheiro é uma não questão para o filme. As três irmãs querem ser reconhecidas, mais que dinheiro, mas o dinheiro é um problema constante.

Seriam essas personagens o problema dos filmes ou seriam os filmes um problema para as personagens? Impossível ter a resposta na ponta da língua porque a escolha de uma personagem é já um ponto de vista sobre os desejos implicados na realização de um documentário. E a forma com a qual a aproximação se dá com esses personagens é, com intenções conscientes ou ausências de intenções mais refletidas, uma forma de colocar o corpo fílmico no mundo. Não se filma os enfáticos da miséria sem ter de lidar com as razões e com os efeitos dessa escolhas. E isso não significa reprovar a escolha, mas questionar sua forma de condução. 
Podemos, entretanto, conceber a representação como um campo de forças cuja gênese é anterior à circunstância da tomada, e na qual se inscreve, irreparavelmente, aquele dano infligido à 'parcela dos que não tem parcela' (segundo a expressão de Jacques Rancière). Por mais "inclusiva" que essa representação queira ser, sempre sobrará, fora dessa conta, a parcela nãoincluída (GUIMARÃES, 2010, p.184).

Há quem trabalhe em outro lado desse mesmo universo, ou seja, a partir de filmes não sobre seres espetaculares, marcados por contextos agressivos e de alta combustão dramática, mas seres comuns, ordinários, sem qualidades evidentes, por isso mesmo estimulantes apenas para observadores atentos, sem pressa, sem sede de energias explosivas. Há uma reivindicação reativa nessa postura, contrariada com o humanismo "mundo cão", que solicita olhar carinhoso, aberto e sem tipificação para esses seres ordinários, interessados no mínimo denominador incomum, no irredutível de cada um.

Guimarães, tem se debruçado sobre esse recorte. Cita Maurice Blanchot no começo de seu ensaio "Comum, ordinário, popular: figuras da alteridade no documentário brasileiro contemporâneo", quase uma plataforma estética e política para essa defesa do mínimo como força sensível. Para Blanchot, o cotidiano ordinário não é momento de espera do maravilhoso, mas uma região, aquém do que o afirma e além do que o nega. Para Guimarães, o documentário empenhado em filmar o outro, que ele prefere chamar de ordinário (sinônimo de comum e qualquer), investe em polarização excessiva, criando um desequilíbrio de poder com aqueles filmados (Idem, p 183).

O autor acredita que o homem do povo, se retirado do selo dos "sem parcela" e incluído entre os com algum título, passa a ostentar uma "propriedade imprópria" (Ibidem, p.184). Cabe um posicionamento a contrapelo. Não seria esse investimento no outro de classe, como uma potência a ser cultivada para ele ser inserido pelo afeto estético, uma forma de resignação do sensível. O outro deixa de ser outro, distante das câmeras e das telas, por certa forma de ser filmado, por uma forma de relação proposta pelos realizadores, por uma abertura para se reinventar e, naquele espaço do filme, pode ser o mesmo sendo outro, ou ser outro sem perder-se de si? Ignorar a situação social na qual esse outro está colocado seria a nova política.

Talvez possamos pensar o regime estético (da arte) proposta por Jacques Rancière e analisado por Ismail Xavier. O regime estético seria capaz de fazer "emergir o esplendor puro do ser, a potência expressiva inscrito nas coisas mesmas, no 
insignificante" (Xavier apud Mesquita, 2010. p.200). É a partir desse regime que Claudia Mesquita detecta no documentário brasileiro recente uma novidade: um afastamento da entrevista e a assuntos prévios (coisas diferentes) e investimento na presença bruta e na superfície imediata do cotidiano (MESQUITA, 2010.p 200), que seriam notáveis em filmes como Acidente (2006), de Cao Guimarães e Pablo Lobato, abertos a construir uma poesia do banal.

Talvez não sejam tantos os filmes a seguirem esses pressupostos, que guardam heranças de Cesare Zavattini e André Bazin, ambos, por diferentes razões e estratégias, defensores de uma estética da presença, da ambigüidade vacinada contra sentidos fechados. Talvez existam outros filmes, muitos já analisados por Mesquita, como Morro no Céu (2010), de Gustavo Spolidoro, Avenida Brasília Formosa , de Gabriel Mascaro, e A falta que me faz, de Marilia Rocha. Pode ser uma nova linha a ser seguida, mas ela estava presente em outros filmes anteriores, como A Alma do Osso, do mesmo Guimarães, Vilas Volantes, de Alexandre Veras, e mesmo Aboio, de Marilia Rocha, mais questão de autorias e, talvez, nem tanto questão de momento histórico.

\title{
Intervalo 6 - retrato, micro história
}

Claudia Mesquita tem trabalhado em cima dos discursos particularizantes, novidade recente em contraposição à tradição moderna dos anos $1960^{\circ}$.

\begin{abstract}
Contrariamente ao que era tendência no documentário moderno (sobretudo aquele dos anos de 1960 e 1970), hoje se nota evidente suspeita em relação a procedimentos totalizantes e interpretativos, às possíveis sinédoques (os personagens tomados como tipos representativos, em relação a um contexto ou situação englobantes), ou ao posicionamento dos sujeitos filmados como informantes (sobre uma temática). Em resumo, evita-se remeter o dado pessoal a um quadro geral; declinam valores tais como representatividade, generalidade, tipificação, diagnóstico crítico, e outros valores assomam (2010).
\end{abstract}

Mesquita localiza entre os outros novos valores assomados as abordagens concentradas em um único ou em poucos indivíduos, como são os casos de Estamira e $A$ Pessoa é para o que Nasce, assim como de curtas, médias e longas com nomes próprios nos títulos, cuja lista é extensa e engloba desde lançamentos com repercussão crítica, como Nelson Freire (2003) e Santiago (2007), de João Moreira Sales, até trabalhos menos evidentes

\footnotetext{
${ }^{9}$ MESQUITA, Claudia. Retratos em diálogo - Notas sobre o documentário brasileiro recente. Novos Estudos - Cebrap: São Paulo, março de 2010
} 
e analisados, como os longas Nos olhos de dona Mariquinha (2009), da própria Claudia Mesquita, e As Iracemas (2009), de Alexandre Pires Cavalcanti. Ao contrário dos filmes polifônicos de Eduardo Coutinho, que se tornou o diretor de procedimentos paradigmáticos desde o fim dos anos 90, esses títulos de nomes próprios são de "documentários solos", termo empregado aqui para se acentuar esse caráter de enfoque sobre personagens únicos (com a aplicação dúbia e dupla do termo "único") ${ }^{10}$.

Claudia Mesquita vê esse movimento de particularização do enfoque como sintoma da dificuldade de se representar a experiência social e coletiva, constatação de um fenômeno e de uma tendência, que, ainda segundo ela, teriam analogias com a micro-história ${ }^{11}$, com as investigações baseadas em análises de fenômenos circunscritos, nos termos de Carlo Ginsburg. Essa tendência a individualização foi detectada pelo crítico Ismail Xavier em uma entrevista na qual afirma que a procura, no documentário brasileiro a partir dos anos 90 , é pela singularidade, com conseqüente fuga das generalizações e dos processos sociais, como se situações vividas pelos sujeitos fossem em si. Xavier vê como efeito dessa estratégia um inventário de imaginários "sem relação entre eles e as condições materiais da existência, sem saltos da experiência imediata para suas implicações sociais e políticas" ${ }^{\prime 2}$.

Etnografia discreta é o termo com o qual o crítico define o procedimento de recolhimento da enunciação de abordagem generalizante e a afirmação de uma subjetivação do indivíduo. De acordo com Xavier, "Vivemos num período em que se tenta evitar a discussão de estruturas sociais. Diz-se que os problemas estão nas consciências, nas idiossincrasias de determinados políticos, em aspectos do dito caráter nacional, no que quer que seja, e não nas estruturas"13. Essas manifestações de "eus" em geral (no particular) é viabilizada pelas palavras ditas em entrevistas e em um processo narrativo e dramático de construção de personagens.

Tomando como centro de análise o método de Eduardo Coutinho, sobretudo em Edifício Master, Xavier avalia que o entrevistado, nesse novo paradigma, tende a apropriar-se da cena para se afirmar. "(...) Há um quê de confessional, mas que nada tem a ver com cobrança de instituições de controle do Estado. É um falar de si, da intimidade, que torna quem fala uma 'personagem' no sentido etimológico do termo (ou seja, uma figura pública)"14. Ou seja, tornar-se visível, ser ouvido, ocupar lugar no audiovisual, espaço de políticas públicas e

${ }^{10}$ Embora não sejam necessariamente "retratos", como são definidos por Claudia Mesquita os documentários construídos na relação explícita entre documentaristas e personagens, a autora enumera em nota uma lista abrangente de documentários biográficos de 1997 a 2008.

${ }^{11}$ GINSBURG, Carlo. A micro-história e outros ensaios. Rio de Janeiro: Betrand, 1989.

${ }^{12}$ XAVIER, Ismail. O cinema brasileiro dos anos 90. Praga: Estudos Marxistas, 2000, $\mathrm{n}^{\circ} 9$.

${ }^{13}$ XAVIER, Ismail. Encontros inesperados: entrevista com Ismail Xavier. In: CONTI, Mario Sergio. Folha de São Paulo, Editoria MAIS, 03 dez. 2000

${ }^{14}$ XAVIER, Ismail. Indagações em torno de Eduardo Coutinho. Cinemas - objetivo/subjetivo, n.36, Rio de Janeiro: Aeroplano, out/dez.2003 
pessoais. No mesmo artigo, o crítico afirma que o princípio desse método procura o interesse do personagem fora dos estereótipos, recuperando na entrevista um sentido de "autoconstrução", de eu inigualável, que não é reduzível a um modo de vida em comum com outras vidas.

É importante notar que a autoconstrução, ou a auto-mise-en-scène, como define Claudine de France ${ }^{15}$, é um processo dialógico e não monológico, para citarmos os termos de Bakhtin e, por extensão, incluirmos o pensamento do austríaco Martin Buber (1982), para quem toda vida é mercada pelo encontro, relações, com as diferenças expostas para se melhor relacionar. Importam na autoconstrução as relações de pesquisa e de filmagem, que podem ou não serem respeitadas e potencializadas na montagem. O eu construído para si e por si a partir da visão e da fala do outro. E não um eu acima de quaisquer situação, monológico, que ignora o outro, sem o qual não estaria ali. Sua evidência só é possível em razão da interação (entre quem filma e quem é filmado), da consciência da câmera e da imagem pública em elaboração em uma cena particular (não em um palco ou palanque). Não se trata de uma construção solitária.

A aplicação da noção de auto-mise-en-scène, de forma geral, tende a ser condicionada a uma manifestação (da parte dos filmados) de gestos e falas enfáticas, presenças sublinhadas, com algum nível de intensificação da situação, como se a noção de "auto" (ou de consciência da câmera) fosse determinada por uma exteriorização espetacularizada, sem possibilidade de se manifestar em operações de retraimento, discrição ou mesmo de defesa. Há uma tendência em se verificar a autoconstrução, portanto, apenas em situações de rentabilidade cênica, nas quais os personagens são produtivos para a cena ${ }^{16}$. Quem não extrapola, não se expande em quadro, estaria aquém da "auto" (construção ou mise-en-scène).

O fenômeno da particularização do enfoque é analisado pelo viés da micro-história por Karla Holanda ${ }^{17}$. Partindo do modelo sociológico difundido por Bernardet, no qual o indivíduo particularizado está a serviço da representação de seu lugar na sociedade, a pesquisadora contrapõe a esse esquema, definido como totalizador, uma noção (não nominada) de microdocumentário, que passou a ser o norte predominante a partir dos anos 90. Essa mudança seguiria rumos mais amplos da contemporaneidade, segundo Holanda, em sintonia com a crise da historiografia e das teorias sociais nos anos 1970 e 1980, também incapazes de lidar com diagnósticos gerais. A micro-história seria uma alternativa de abordagem, com observação

\footnotetext{
${ }^{15}$ FRANCE, Claudine de. Cinema e antropologia. Papirus: Campinas, 1994.

${ }^{16}$ Desenvolverei em outro capítulo essa relação da cena e da auto-construção no documentário a partir de outros artigos de Ismail Xavier sobre o método de Eduardo Coutinho.

${ }^{17}$ Holanda, Karla. Documentário brasileiro contemporâneo e a micro-história. Devires, Cinema e Humanidades, 2004, vol.2, n 1.
} 
mais concentrada e sem ambição de síntese, privilegiando o minúsculo, tramas banais e gente comum, nas palavras de Ronaldo Vainfas ${ }^{18}$.

Como resultado dessa proximidade com a micro-história, o micro-documentário, particularizando seu enfoque e evitando o representativo, constrói indivíduos fragmentados, mais plurais e humanos, de acordo com Holanda. É preciso relativizar essa aparente comemoração crítica em relação à particularização e levar em conta a possibilidade do particular conter sinais (e não apenas índices) de um mundo anterior e além do sujeito sem deixar de conter esse sujeito e de estar contido nele. O encaminhamento para o particular da micro-história não varre o campo social das manifestações da experiência pessoal. Um dos clássicos dessa vertente historiográfica, $O$ queijo e os vermes, de Carlo Ginsburg ${ }^{19}$, não está atrás da subjetividade de seu personagem estudado, Menocchio, o moleiro italiano perseguido pela Inquisição na Itália, mas de sua construção individual como reação à suas condições sociais e culturais.

Se a micro-história centra seu trabalho numa "descrição mais realista do comportamento do homem no mundo, esse comportamento se dá diante de uma realidade normativa, "resultado da negociação entre as limitações impostas por sistemas normativos, prescritivos e opressivos" ${ }^{20}$, que entram em relação e tensão com a liberdade pessoal. $\mathrm{Na}$ problemática enfocada em nossa pesquisa, levantamos a hipótese de que, em nome de uma fuga da tipologia representativa, alguns documentários reduziram os indivíduos a espécies de "figuras-tatus", que se fecham em si mesmos, como se vivessem com autonomia, de forma autista e não relacional, tornando-se vidas suspensas do mundo social no qual suas experiências e existências são realizadas e impedidas.

Muito diferente de Cabra marcado para morrer, no qual o diretor narra e é narrado (voz de Ferreira Goulart), fala de sua experiência e a conecta com o mundo histórico, coletivo, no qual vive uma nova experiência, mas sempre em relação a sua personagem central, Elizabete Teixeira, e aos coadjuvantes com os quais toma contato, todos também biografados e colocados dentro das relações mais amplas. As vozes se completam, dialogam, manifestam algo de particular, mas sem abrir mão do contexto geral.

O documentário brasileiro encaminhou-se para uma situação na qual os cineastas deixaram as imagens sem povo, sem questões e sem temas, optando pela procura de personagens que carregam os filmes nas costas, com suas subjetividades expressas em atos de fala e gestos maiúsculos.

\footnotetext{
${ }^{18}$ VAINFAS, Ronaldo. Os protagonistas anônimos da história: micro-história. Rio de Janeiro, Campus, 2002. Apud. Holanda, Karla. Documentário brasileiro contemporâneo e a micro-história. Devires, Cinema e Humanidades, 2004, vol2, $\mathrm{n}^{\circ} 1$.

${ }^{19}$ GINSBURG, Carlo. O queijo e os vermes. São Paulo, Companhia das Letras, 1996

${ }^{20}$ LEVI, Giovanni. Sobre a micro-história. In: BURKE, Peter (Org.). A escrita da história: novas perspectivas. São Paulo: Ed. Unesp, 1992
} 
Em entrevistas e debates com participação de Eduardo Coutinho, agora cada vez menos preocupado com as questões gerais e cada vez mais com as específicas da pessoa em quadro, é constante o emprego do termo "extraordinário", ou, em outras palavras, é freqüente a explicitação por parte do cineasta da procura por personagens talentosas em suas (auto)narrações. Não há lugar nessa espécie de darwinismo da fala e da cena para os medíocres cênicos, com pouco talento para se fazerem visíveis e audíveis.

O que se pressupõe, nas reflexões recentes sobre o documentário dos retratos e da individuação, é a defesa da beleza. O documentário estaria ou deveria estar comprometido com um humanismo estético pouco preocupado com o mundo material e social para melhor chegar a uma subjetivação dos personagens. No entanto, na produção filme a filme, a realidade é outra. Há mais palavras que silêncios, mais entrevista que conversa, mais vampirismo que encontro.

À essa defesa da estética do afeto, como colocada por Guimarães e Mesquita, faltam mais filmes. É, antes, solicitação. Guimarães em seu ensaio já citado, por exemplo, alinha-se a Commoli, Ranciére, Blanchot, Michel de Certeau, mas antes de citar o primeiro filme, Boca de ouro (1992), após 10 das 15 páginas do ensaio, recorre a um fotógrafo (Raul Garcez) e a uma escritora (Clarice Lispector), ambos que expressam suas demandas. É sintomático. Parece não haver documentários brasileiros recentes a altura das expectativas do autor, o que torna sua reflexão mais teórica e programática que a partir dos filmes existentes.

O documentário brasileiro está, em sua maior parte do tempo, do outro lado dessa mesma rua. Lida em muitos títulos com personagens precários, mas o faz à procura de talentos sensacionais, a partir de suas ausências de parcela. Um documentário da exploração e não da construção. Há uma certa padronização dos personagens em suas diferenças. E, sendo mais enfáticos e barulhentos, sendo mais silenciosos e introvertidos, não importa, aqui, a diferença, porque, em quaisquer das perspectivas, predomina a necessidade do personagem. Parece ser exclusividade dos filmes e dos diretores analisados por Fernão Ramos em sua lógica da culpa e do narcisismo ás avessas o olhar para a sociedade. Ônibus 174 (2002), de José Padilha, será 
o único caminho, na prática, para um documentário que, sem abrir mão do personagem (no caso, morto), conecta-se com social? E não se trata de uma defesa, longe disso, apenas de uma interrogação?

Procurar a lógica do personagem não tem sido exclusividade do documentário. A ficção brasileira recente, já construída necessariamente sobre personagens, tem investido na primeira pessoa, desde pelo menos Carlota Joaquina (1995), de Carla Camuratti. Muitos filmes trabalharam com essa dinâmica, inclusive Cidade de Deus (2002), de Fernando Meirelles, e Tropa de Elite (2007), de José Padilha, talvez porque os posicionamentos dos filmes, nesse momento histórico, tenham recuado e tornado mais ambíguos, palavra essa em alta no estudo sobre cinema e documentário.

Talvez seja essa uma das razões da recusa de Bernardet aos filmes considerados categorizáveis como sociológicos. Viramundo e Maioria Absoluta são filmes com posicionamentos claros e firmes. Não se trata de colocar um modelo sobre o outro, mas justamente o contrário disso: desenterrar certa tradição social de um crematório ao qual foi submetida. A voz dos filmes virou cinzas, daí um documentário como Cidadão Boillesen (2009), de Rodrigo MacNiven, ser hoje quase um peixe fora d'água.

\section{Intervalo 7 - a entrevista, o poder e a mise en scène}

A entrevista não é a única operação do documentário brasileiro contemporâneo, também abertos a outras operações, mas continua sendo a principal forma de aproximação entre diretor e personagem, a principal forma de construir um personagem, o momento e processo no qual o "efeito câmera" mais se faz notar desde Jean Rouch. Sem uma tradição de cinema direto, observacional, o documentário no Brasil sempre valorizou a palavra. Nos últimos anos, palavras de personagens, muitos com carências visíveis. Irei elencar algumas observações, em diálogos com outros pesquisadores, para melhor lidar com essa predominância.

1) Jean-Claude Bernardet no anexo de Cineastas e as imagens do povo critica o automatismo da entrevista no documentário brasileiro, sempre pautada pelo olhar do entrevistado para o lugar onde está o diretor, em geral ao lado câmera, e pelas perguntas direcionadas pelo diretor já em busca de certas respostas. O autor destaca Nelson Freire, de João Moreira Salles, como exemplo de um filme que, em dados momentos, consegue pela 
imagem chegar a pontos que a palavra não expressaria, sensações, emoções, porque ali o diretor coloca-se de forma mais silenciosa e observadora.

2) A observação acima, sobre a visão de Bernardet, avesso ao entrevistismo como muleta, coincide com as de Guimarães e Mesquita, em parte também com a de Migliorin, quando elogiam a observação do miúdo, os silêncios, o tom mais ameno, menos enfático, assim como menos roteirizado por visões prévias. Uma pergunta é uma pauta. Uma observação é abrir ao acontecimento da situação de filmagem, ao efeito-câmera, sem as esquematizações prévias da entrevista. No entanto, a observação, como princípio, é uma curiosidade, com alto potencial de indiscrição, que não retira o poder do realizador sobre as pessoas filmadas. Dependendo do caso, muito pelo contrário.

3) Talvez pela força de nossa televisão no Brasil, a entrevista e os personagens aqui ganham uma dimensão raras vezes encontradas nas discussões em outros países. Tema de um especial estampado na capa dos Cahiers du Cinema em 2004, edição de outubro, número 594, o documentário analisado pelos críticos da revista passa longe dessas duas questões. Mesmo quando tratam de um cineasta como Wang Bing, capaz de passar horas diante de seus entrevistados, não é nos personagem e nas relações de poder que os textos se concentram, mas nos vestígios de um mundo histórico obtido pelo diretor em sua economia de mise en scène

4) Em Massa e Poder, Elias Canneti afirma que a pergunta é uma estratégia de poder, com sua capacidade de penetrar, como uma lâmina, na carne do questionado, intrometendose, cortando fundo, pois já se saber de antemão o que se busca. Por isso, cria estratégias, de modo a saber mais, mesmo sem o questionado ter noção desse jogo de interesse e desinteresse, presente em todas as entrevistas. Uma entrevista em documentário é uma forma de diminuição de distãncia e de se chegar ao outro a partir de curiosidades específicas (motivo da escolha de se entrevistar e de se filmar essas e não aquelas pessoas). Canetti lembra que o que nos dá segurança,em relação aos estranhos, é a aparente garantia de não ser interpelado.

5) Stela Senra afirma que, na televisão brasileira, o povo, quando entrevistado, é tratado com misto de autoritarismo e paternalismo (SENRA, 2010. p104).

Enumerei essas leituras apenas para criar uma montagem assumidamente fragmentada que coloca a entrevista e o personagem como um nervo ainda exposto no documentário brasileiro. Nossa consciência culpada e o silêncio ao qual o outro de classe ficou condenado por tanto tempo parece nos estimular a querer sempre ouvir quem antes não podia falar. No entanto, se em alguns casos há clara atração pelo pitoresco ofertado pela diferença do outro em relação ao padrão da elite consumidora e realizadora de cinema, muitas vezes 
confundido com solidariedade, por outro lado há casos de registros de presença sem nenhuma esquematização de sentidos, colocando o documentário no limite de um museu da pessoa.

Se parece haver exagero retórico nas afirmas de Canetti, concordo quando ele valoriza as estratégias do perguntador (eu ampliaria para o filmador calado) como forma de se conseguir algo (informação, sinal, reação) sobre o qual o questionado (o filmado) não controla. Há uma espécie de armadilha (às vezes, em nome de ótimas intenções) em toda situação de filmagem. Evito aqui a palavra encontro porque esse encontro, se assim o chamar, será sempre marcado por um único lado, o do documentarista atrás de seus personagens.

Mesmo na visão defensora das estratégias de recuo de poder do documentarista, convenhamos, o poder continua com ele e está nesse poder sua mise en scène, sua visão, sua moral como gostam de falar os franceses. Diria sua política. Porque toda política é uma forma de equilibrar ou manter poderes, mas para tal quem deve equilibrar é o destituído de poder, não aquele que o detém. Esse faz uso do poder, não necessariamente para o "mal" ou contra seus personagens, e, se pode cumprir a missão de democratizar o espaço das presenças e discursos, não pode abrir mão dessa condição inevitável de poder, ou mais justo seria entregar os equipamentos para os personagens e deixarem eles fazerem seus próprios filmes.

Minha contribuição nessa discussão é muito simples. Assumamos o poder de quem filma e as relações de poder de uma filmagem, sem ver nessa negociação uma tensão ou um processo nocivo, porque, do contrário, entramos em um território da irresponsabilidade, dos autores alérgicos às implicações da autoria, também essa uma forma de exercer controle e de ser mantida sob controle, uma das molas propulsoras da política. Poderes implicam responsabilidades de quem o detém. Não era de outra coisa que falava Jacques Rivette em "Da Abjeção" quando atacou Kapo e Gillo Pontecorvo por não se colocar questões prévias.

Falava de poder e mise en scène. Embora essa noção (a de por em cena, encenar, modular espaços e movimentos, exercer controle sobre visível e fora de quadro) seja mais vinculada á ficção, o documentário também a utiliza na prática. Pergunta Fernão Ramos em "A mise en scène do documentário: no que a imagem de pelo fato de ser mediada pela câmera transfigura a ação que transcorre na cena?" (RAMOS, 2011). Transfigura ou provoca? Seguindo certa tradição francesa, Ramos valoriza a forma de filmar o corpo como coração da operação de por em cena, um corpo filmando o outro, embora em situações muito distintas. Se na ficção esse corpo é dirigido, no documentário, longe de não sê-lo (vide Santiago quando João Moreira exige de seu ex-mordomo que abaixe a cabeça, levante-a suavemente, pedindo para repetir várias vezes o movimento), torna essa relação mais dialógica. É preciso, da parte do realizador e do fotógrafo, prever ou esperar. 
Não retiro dessa discussão as operações de montagem (ou edição). São as associações entre planos, a duração deles e a decisão de colocá-los fora que determinam essa disposição de um olhar, já distante do momento da captação, do contato, já com um recuo capaz de produzir de fato um olhar no documentário. Porque no calor da filmagem ou das gravações, na maioria dos casos, impera a intuição e um racionalismo muito moderado. $O$ poder é exercido, no documentário, não apenas, mas principalmente na montagem. Ou em um roteiro de perguntas.

Em muitos casos, porém, esse poder, longe de ser exercido contra, é pensado como benefício do filmado. Há certa arrogância da parte dos documentaristas e da maioria dos pesquisadores de investir o documentário de um poder sobrenatural sobre as vidas privadas e públicas. Se em alguns filmes o filmado é beneficiado na pele temporariamente, como em Lixo Extraordinário, sobre os efeitos políticos e subjetivos da reciclagem do lixo transformada em arte, em outros parte-se do princípio de que o outro de classe é uma vítima a ser resgatada pela imagem, na imagem na verdade, partindo de uma premissa pouco equânime, para, por meio do documentário, procurar tornar menos distante esses poderes. Não seria uma estratégia de apaziguamento de responsabilidade social, forma conveniente de agir? Talvez. Provavelmente. É necessário insistir para além dessa pesquisa nessa questão.

Recorro a uma passagem do resumo de Marcius Freire em "Relação, encontro e reciprocidade: algumas reflexões sobre a ética no cinema documentário contemporâneo", na qual afirma que, independentemente de método e contingência de filmagem, quem detém a câmera detém um poder e ele é completo no momento da montagem/edição. Como coloca o autor, está ai, nesse poder do qual não se tem como abrir mão, a ética do documentário (FREIRE, 2007, p.13).

Freire cita um debate entre Jean Rouch e Sembéne Ousmane em meados dos anos 1960, quando o segundo disse ao primeiro que filmava os africanos como se fossem insetos e, na continuidade, deu sua aula de cinema ao dizer que ver não é suficiente, é preciso analisar, saber de onde vem o homem andando, para onde vai, enfim, colocar o fora de quadro em quadro, colocar as presenças em contingências e em contexto com o que não está na imagem. Poderia acrescentar que uma imagem, antes de ser o que ela mostra, é o que deixa de fora. Uma imagem, tanto quanto incluir, exclui. Essa é a noção de enquadramento e montagem que me interessa colocar em discussão. A presença pode ser bonita, encantador, comovente, pode dizer algo de alguém, mas o que diz para além disso. Não seria se contentar com pouco para não se assumir responsabilidades maiores?

Há, portanto, na realização de todo documentário, uma relação de poder, o realizador queira ou não, na qual ele detém o domínio sobre um processo em construção, enquanto as pessoas filmadas a ele são submetidas. Evidentemente, como bem mostrou Michel Foucault, "onde existe o poder, existe resistência e, não obstante — ou por isso mesmo 
—, esta jamais se situa em posição de exterioridade em relação ao poder". (Idem, p.15).

A citação de Foucault está em História da Sexualidade, na página 125 da edição francesa de 1976 e é a deixa para Freire trazer o caso da cineasta Leni Riefenstahl, que, em um momento de The wonderful, horrible life of Leni Riefensthal (1993), de Ray Muller, opõe-se a certas imprecisões ou sugestões do documentarista. Podemos ainda pensar em um momento de Um lugar ao sol (2010), de Gabriel Mascaro, centrado em entrevistas com moradores de cobertura de São Paulo, Rio e recife, quando uma entrevista, desconfiada das intenções do realizador, pede para ele desligar a câmera. O diretor desliga, mas mantém o áudio, que nos permite ouvir sua desconfiança e, na sequência, sua retirada da situação de entrevista.

Parte do artigo de Freire é centrado nas experiências antropológicas e etnográficas, nas quais, antes de ser outro de classe, esse outro é de cultura (idioma, modos, territórios). Podemos considerar o outro de classe, contudo, como uma matéria prima para uma etnografia amadora, discreta como coloca Ismail Xavier, sem assumir que está ali para desbravar o desconhecido, lidar com um mundo novo, colocar a câmera e a montagem com microscópio, do qual muitas vezes não se extrai muito além da evidência do inseto ali presente.

Revista Galáxia, São Paulo, n. 14, p. 13-28, dez. 2007.

O modelo egológico pauta-se, em alguma medida, por uma etnografia do indivíduo, uma egografia de vítimas. Elas aparecem, falam, cantam. A historiadora argentina Beatriz Sarlo, ao escrever sobre a historiografia voltada para as vítimas de guerra a partir de seus próprios relatos, questiona a crença inflacionada no testemunho (2007). Existe uma vaidade do sofrimento, pautada na lógica do eu estive lá, do eu sobrevivo apesar de tudo, que carrega certo heroísmo da falta e do sofrimento, baseado nos movimentos movediços e superlativos da memória.

Sarlo cobra dos historiadores que, em vez de apenas ouvir e descrever, façam seu trabalho completo, analisando outras fontes e cruzando os testemunhos com elas, sem apostar cegamente no empirismo de quem fala. Mais ou menos, ou exatamente o mesmo, que Sambéne Osmane cobra de Jean Rouch: não se contente com o que está vendo com sua lente. Mesmo Vertov, que acreditava na superioridade da olho 
maquínico sobre o olho humano, centrava a verdade das imagens nas relações entre elas, ou seja, na capacidade humana de lidar com as presenças registradas.

Essa crença ou fetiche na palavra prova de presença e olhar em dado situação limite, como mecanismo de revelação, está inserida por Sarlo ${ }^{21}$ em um fenômeno de "guinada subjetiva" nos estudos culturais após os anos 70, com minorias e vítimas empenhadas em falar para quem quiser ouvir, o que, se transposto para o documentário, levaria em breve alguns candidatos a personagens se oferecerem para documentaristas. Como diz em tom de anedota cruel um pesquisador em conversas informais, a classe média procura a televisão para ser alguém na imagem, mas aos pobres e vítimas só restam o documentário.

A tendência acadêmica e de mercado de bens simbólicos que trabalham com a textura da vida, a valorização de verdades abrigadas na rememoração, a dimensão subjetiva dos relatos e o inflacionamento da primeira pessoa após sua dissolução nos estudos das estruturas sociais, segundo a autora, são passos de um programa que se torna explícito em função de condições ideológicas. "Restaurou-se a razão do sujeito" ${ }^{22}$, que foi, até três décadas, mera 'ideologia' ou 'falsa consciência', isto é, discurso que encobria esse depósito escuro de impulsos ou mandatos que o sujeito necessariamente ignorava", afirma Sarlo.

A história oral e o testemunho, continua a crítica argentina, "restituíram a confiança nessa primeira pessoa que narra sua vida (privada, pública, afetiva, política) para conservar a lembrança ou para reparar uma identidade machucada". Por vivermos em época de forte subjetividade, as prerrogativas do testemunho se apóiam na visibilidade do pessoal como "lugar de intimidade e de manifestação pública". Se há três décadas o eu manifestava suspeita, ela salienta, hoje nele se reconhecem privilégios.

\footnotetext{
${ }^{21}$ SARLO, Beatriz. Tempo Passado - Cultura da Memória e Guinada Subjetiva. São Paulo: Cia das Letras, 2007

${ }^{22}$ Grifo da autora
} 


\title{
4. Qual seu talento?
}

\section{A ditadura da rentabilidade em nome da democracia cênica}

$\mathrm{Na}$ economia do conhecimento, todo trabalho contém componente de saber cuja importância é crescente. Não saber técnico, aprendido em escolas, mas saber da experiência, capacidade de auto-organização e de comunicação, um saber vivo, que exige investimento de si, "motivação" na linguagem empresarial (GORS, 2005: 9). O resultado é avaliado por chefes ou clientes. Toda produção passa a ser tratada como prestação de contas. O valor do trabalho, ainda segundo esse raciocínio (e essa prática), nada tem a ver com tempo aplicado.

\begin{abstract}
Os fatores que determinam a criação de valor são o "componente comportamental e a motivação", e não o tempo de trabalho dispendido. São esses fatores que as empresas entendem como seu capital humano. Desfeitas as relações convencionais de salário, resolveu-se a questão a respeito do modo como o capital consegue exercer poder sobre os homens e é capaz de mobilizar a todos: os empregados têm de se tornar empresas que, mesmo no interior de grandes estabelecimentos industriais, devem responder pela rentabilidade de seus trabalhos" (Idem: p.10)
\end{abstract}

Essa nova fase do capitalismo, dita imaterial, pós-moderna, cognitiva, com uma knowledge economy e uma knowledge society, é centrada na qualidade do comportamento (envolvimento pessoal na tarefa desenvolvida), em uma vivacidade na utilização dos saberes do cotidiano. É o contrário do fordismo: para se tornar um operador da produção, o trabalhador tinha de ser despojado do saber cotidiano, de modo a assimilar um saber técnico, que podia ser dominado por outros tantos. Para ser domesticado, esse trabalhador, na segunda metade do século XIX, era submetido a métodos disciplinares (IBIDEM: 19). Como afirma Yann Moulier-Boutang em "La troisième transition du capitalisme" 23 , o trabalhador não se apresenta mais apenas como possuidor de sua força de trabalho hetero-produzida, mas como um produto que continua ele mesmo a se produzir.

Em 1990, Charles Handy e William Bridges escreveram que, em futuro breve, haveria apenas empresas individuais, com prestações de serviços individuais (IBIDEM: 24). Nessa configuração, a fronteira entre o que se passa fora do trabalho e no trabalho apaga-se, pois toda atividade torna-se negócio e, citando Pierre Levy, "todos estão

\footnotetext{
${ }^{23} \mathrm{O}$ artigo foi publicado em Vers un capitalisme cognitif, organizado por Christian Azais, Antonella Corsani e Patrick Dieuaide. L`Harmattan, Paris, 2000
} 
constantemente ocupados, prontos a se conformarem ás exigências das novidades. A pessoa se torna um empreendimento”. (LEVY, 2000, p. 84-86). Ainda segundo Levy, “o desenvolvimento pessoal mais íntimo conduzirá a uma melhor estabilidade emocional, a uma abertura relacional mais natural, a uma acuidade intelectual melhor dirigida e, assim, a um melhor desempenho econômico" (Idem: 83).

Não há, consequentemente, desemprego. Porque mesmo os beneficiados pelo seguro desemprego, na verdade, estão sendo pagos para procurar emprego. Ou seja, para trabalhar, mesmo sem emprego, o que exige "aquisição de competências mais vendáveis do que aquelas que ele já possui” (GORZ, 2005: 26). Alguns autores reivindicam uma "renda de existência", que remuneraria o tempo livre, também fundamental para o trabalho. Se o tempo livre não é mais livre, mas condicionado ao tempo do trabalho e remunerado por um pagador para quem o trabalhador está de folga, de modo a produzir melhor (em alguma atividade de lazer da empresa, como competições esportivas e outras ações de interação social), então ele passa a ser tempo submisso, útil, produtivo.

(...) essa interpretação considera que a vida inteira se tornou produtiva como produção de capital humano fixo. Toda a produção de si é assim rebaixada a trabalho econômico. Este é considerado como seu sentido objetivo. Todo mundo contribui para a produção social simplesmente por viver em sociedade, e merece pois essa retribuição que é a renda de existência (Idem: 27)

Não apenas o trabalhador é pensado e operado como indivíduo empreendedor de si mesmo, cultivando a competitividade com e contra outras empresas individuais, mas também o consumidor é seduzido por sua particularidade, desde há muito, sendo construído como "o contrário do cidadão, como o antídoto da expressão coletiva de necessidades coletivas, contrário ao desejo de mudança social, à preocupação com o bem comum" (GORZ, 1988: 63). A publicidade opera, por conseguinte, não junto à imaginação de todos, mas a de cada um, a cada pessoa privada, a cada empresa de compra de produtos e venda de serviços a prestar. "Ela promete a cada um escapar à condição comum tornando-o um 'feliz privilegiado' que pôde oferecer a si mesmo um novo bem, mais raro, distinto (Ibidem).

Ainda de acordo com Gorz, a indústria publicitária promete soluções individuais para problemas coletivos e apela a cada um "que recuse sua existência social como indivíduo social que é. Ela é uma socialização anti-social" (Idem: 66). Depende, porém, da criação servil, mercantilista, que pouco têm de artísticas. Sua estratégia e seus objetivos nada têm a ver com "libertar a sensibilidade dos clichês, dos estereótipos e dos 
lugares comuns nos quais ela tende a se colar" (GORZ, 2005: 50). O objetivo é antes de tudo o de vender mercadorias como se fossem obras de arte pela propagação de normas estéticas, simbólicas e sociais, que devem ser "voláteis, efêmeras, destinadas a serem substituídas rapidamente por novas normas" (Idem).

Há um direcionamento desse mesmo processo no novo capitalismo para a venda do indivíduo e para a transformação do indivíduo consumidor também em vendedor. Aos 14 anos, Daniil Kulchenk, ucraniano radicado nos EUA, criou a Phenoma, empresa voltada para desenvolvedores de websites, games e programação gráfica a possibilidade de utilizar uma linguagem chamada "Perl". Aos 16 anos, em 2011, vendeu a Phenoma a Active State, companhia canadense especializada em linguagem de programação. Em entrevistas sobre o negócio, nada revelou sobre valores, mas falou de seu aprendizado como empresário, tendo de lidar com advogados, contratos, finanças. O passo seguinte foi ser contratado pela Active State, em esquema contemporâneo, como colaborador terceirizado, que trabalha de casa e transforma o computador, antes ferramenta de lazer, em sua máquina de fazer novos negócios.

\section{Intervalo 8: eu produzo, logo existo}

Ter sucesso em uma liberdade ilusória, atribuída a todos, e desmentida constantemente na realidade cotidiana. Ao se tornar convincente, essa ilusão transformou-se em norma. Hoje, cada um, independentemente de onde venha, deve realizar a façanha de tornar-se alguém por meio de sua própria singularização (EHRENBERG, 2010, p.172).

A citação é tão precisa e sintética que, a princípio, dispensaria comentários. Porém, a frase não se refere a documentários, mas a empresas e trabalhadores, como vinha desenvolvendo. Ehrenberg continuo o raciocínio e afirma que tornar-se si mesmo, na prática, é fazer o melhor papel de si, ser bem sucedido em ser si próprio, em encenar um self aos olhos e sob a supevisão de quem espera essa produção de si.

Si próprio. A expressão nos remete à implicância de David Hume. Em tom de anedota, dizia que, quando interpelado por alquém disposto a falar de si próprio, de seu self, saia correndo, independente de quem fosse, apenas por não acreditar nos em si. Há toda uma discussão na história da arte sobre esse self, não apenas em relações aos ensaios expositivos de uma primeira pessoa, como o de Rousseau em suas Confissões, mas principalmente em relação aos auto-retratos. A melhor imagem de si, não importa qual seịa, mas a melhor. 
Ehrenbeg classifica nosso presente histórico como era dos indivíduos comuns, pelos quais ninguém mais se responsabiliza. Auto-governo. Parece libertário, assim posto, mas implica preços: o da autonomia. Isso remete à discussão semeada nessa pesquisa, especialmente sobre o recuo da responsabilidade do documentarista, transferida agora para o personagem, responsável por suas palavras e por suas presenças em cena. Não deixa de ser pedagógico perceber que mesmo os críticos reproduzem esse processo, falando muitas vezes mais dos personagens, de Estamira, de Maroca, de Poroca e de Indaiá, do que de como os filmes as colocam em quadro. Não é uma apologia da política dos autores, da qual iá assumi distãncia estratégica como método, mas praticar uma política da responsabilidade (de quem filma e monta).

La Revue Documentaire dedicou em 1999, em seu número 14, um número inteiro à relação entre autor e documentário. Embora quase todos os artigos levem em consideração um excesso de autorismo gerado pela "política dos autores" desde os anos 50, que colocavam os autores a frente das obras e geravam em alguns críticos certo autismo, não existe em nenhum dos textos considerações sobre a relação entre autor e personagem no documentário. Iniciadores das discussões sobre o autre, os franceses não os colocam em contato com os auteurs.

Se não se pode inventar no cinema o que já existe fora dele, nas palavras do editor DA revista, Gérard LeBlanc (1999, p5), certamente o autor pode escolher como filmar o mundo e as pessoas, re=inventando-os a partir de suas conveniências e interesses. Sobre a transferência da responsabilidade para os personagens, nada, nem em relação a uma responsabilidade compartilhada (autre + auteur).

Já havia afirmado que, na França, país da interatividade rouchiana, os personagens não são centrais. Não como parte da discussão crítica e teórica. Isso em parte nos ajuda a entender essa omissão ou falta de interesse para a questão. No entanto, se questionam os excessos do método do autor, os franceses não abrem mão dele. Nesse caso (do documentário e de Documentaire), o autor, fetiche mercadológico e cinéfilo tanto quanto criador de universos, tem outro sentido: o do profissional e do olhar, que, na prática, como colocou acima Marcius Freire, tem de responder pelas imagens e sons mostrados.

\section{Documentário de personagem: quem vende e quem trabalha?}

Qual a relação com o documentário brasileiro contemporâneo? Como um empresário de si mesmo contratado por outra empresa (o documentário), o personagem, ator de si mesmo, trabalha diante da câmera para o diretor e para sua própria imagem, 
Precisa, portanto, render. Depende de seu rendimento parte do êxito dramático e narrativo do documentário. O que vende para o diretor? Carisma, performance, uma forma de falar, de estar em situação de filmagem, de relação com câmera e com as pessoas ao lado ou atrás da máquina. O que ganha com isso? Uma imagem pública, que, mesmo vista por uma parcela muito segmentada do universo potencial de espectadores, está preservada em arquivos digitais, em Hds, em cópias em DVD, criando um lugar de legitimação daquele indivíduo.

Deixa-se de ser alguém para se tornar uma imagem-mercadoria que vende o indivíduo como produto, embora esse indivíduo-mercadoria não exista apenas em sua singularidade. Ele pode também significar e revelar valores dos realizadores e da sociedade, dos espectadores e críticos, como as visões resignadas em Estamira e A pessoa é para o que nasce, não apenas de suas personagens, mas também e principalmente da articulação responsável pela construção dessa visão, Como diz Krakauer, quanto mais incorretamente os filmes apresentam a superfície das coisas, tanto mais corretos eles se tornam e tanto mais claramente refletem o mecanismo secreto da sociedade (2009: p.313).

A demanda por produtividade encontra ressonância nos próprios dispositivos de (falsa) autonomia da força produtiva nos quais o capitalismo está hoje baseado. Uma (falsa) autonomia imposta, não escolhida, que promete garantias efêmeras e circunstanciais, mas não assegura liberdade ${ }^{24}$. Os empregados e prestadores de serviços, recém-transformados em empreendedores, continuam dependendo do empregador. Não deixa de ser uma forma de aumentar a responsabilidade do empregado em sua condição de funcionário temporário, que precisa render e fazer a publicidade de seu rendimento, de modo a se manter mais tempo em sua atividade. Assim como o personagem de documentário, que precisa render para ficar mais tempo em cena e ter mais duração de visibilidade, o novo empregado aparenta ter mais liberdade, pois constrói seu próprio caminho, mas também é mais coagido, porque precisa trabalhar dobrado para não perder lugar. No documentário, também há lucro e superávit cênico e dramático, como em toda forma de produção.

\footnotetext{
${ }^{24}$ BOLTANSKI Luc \& CHIAPELLO Éve. O novo espírito do capitalismo. São Paulo: Martins Fontes, 2009
} 
Um retrato cinematográfico sobre o mundo de personagens com os quis os realizadores não compartilham os mesmos valores e o mesmo contexto social sempre revelam mais sobre os produtores dos filmes. Esses momentos de presença, como já afirmei, são envoltos em demanda de rentabilidade. $\mathrm{O}$ espetacular não está somente na TV e na publicidade, mas também no documentário (inclusive alguns elogiados pela crítica e pelos estudos acadêmicos), que assimilou esses paradigmas imagéticos. Porque o documentário, como os personagens, não é instância em si, com propriedades autônomas. É também afetado, como todos, por seu entorno. Seria preciso propor uma possível conexão entre essa reivindicação de ênfase cênica e a noção de performance. Não se trata de conexão simples ou direta. O próprio conceito de performatividade estabelecido pelos Performances Studies e desenvolvido por Richard Schechner é um tanto movediço. Dependendo do teórico, torna-se volúvel, abarcando todos os gestos e ações, sem uma circunscrição minimamente definida, como é próprio das abordagens pós-modernas, às quais os estudos de performances se associam com orgulho em sua busca pela relatividade de todas as afirmações.

A base da performance, que permanece no vale tudo conceitual, é interação e restauração. Não haveria puro improviso e pura invenção, uma primeira vez do performer, em manifestações performativas. A analogia mais próxima seria com os jogos e com os rituais, ambos regidos por regras claras para quem participa. O jogo, para Schechner, tem algo de falso, pois abre fendas na realidade. Performar seria, em suas palavras, ultrapassar convenções, investir em um espetáculo, não sem carga reflexiva, com abertura para salientar o processo da ação. "Performances são feitas de comportamentos reapresentados, de comportamentos restaurados, por ações que as pessoas treinam executar, que praticam, que repetem" ${ }^{25}$. Essa proto-definição abre a possibilidade de tudo ser performance e diminui o caráter interativo e relacional da atividade. Há algo de roteirizado e programado nessa noção, que independeria das contingências nas quais se dá a performance, ou seja, que implodiria a noção de interação. Não é bem assim.

Schechner leva em conta que, para se designar uma ação como performativa, é preciso submetê-la ao contexto sócio-histórico, que é o que, segundo o autor, vai determinar se uma ação é ou não performática. Torna-se performance uma ação já

${ }^{25}$ SCHECHNER, Richard. Performance studies: na introduction. Londres: Routledge, 2002. 
conhecida de quem a faz, talvez de quem a presencie e com ela interaja, mas ação essa modificada justamente por essa interação, mesmo sendo ela programada.

Tomemos o que, para o documentário, podemos reter. Poderíamos considerar performativa toda ação indiscreta, que chama atenção para a própria ação e para o fato dela não ser uma ação isolada, ocorrida apenas ali diante da câmera, uma ação reveladora de um padrão qualquer anterior ao momento registrado pela câmera, assim como uma ação - um tanto paradoxalmente - que deixa visíveis as marcas do processo de sua inscrição na imagem e nos sons. A performance é gerada por algo anterior a seu acontecimento, mas só se realiza no devir da filmagem, justamente por chamar a atenção para si. Diante do emaranhado de relativizações e da abrangência dos estudos especializados na área, é mais responsável não ir adiante com a analogia, sob o risco de me perder no labirinto de alternativas e de abstrações desses estudos.

De qualquer forma, recorro a Mariana Baltar, que tem enfrentado essa relação entre performance e documentário, nada a ver com a categoria de documentário performativo colocada por Bill Nichols, centrado na primeira pessoa dos realizadores. Analisando duas personagens performáticas, Estamira e Sarita (de Jogo de Cena), a autora as junta no mesmo texto por serem performáticas. Reconhecendo o ainda insipiente estudo da performance no documentário, ela leva em consideração a performatividade dos atos de fala encampada por J. Austin, portanto, presente em documentários sustentados pelo discurso verbal (2010, p.219).

Baltar parte de Erving Goffman (1959), com sua idéia de vida como palco e da performance como atividade que, em dada situação, leva alguém a influenciar outro participante da situação. Um eu consciente de si e em busca de certa visão para si (caráter ou projeção moral). Para essa estratégia de convencimento, é preciso recorrer a algumas estratégias, desenvolvidas entre a autenticidade e a encenação, sem separação entre cada uma, mas como soma e fusão entre autêntico e alto-encenado. Que fique claro que a performance, como princípio e prática, visa o controle e a visibilidade. Uma identidade, temporária muitas vezes, a ser alcançado. Um jogo

A autora traz para o documentário esse jogo, no caso entre quem está diante e fora da câmera. Para ela, Estamira é extraordinária em si, com ou sem câmera. O filme teria como projeto, segundo sua visão, retirada de Estamira, a personagem, do estigma da loucura. O poder da superação por meio da performance do cotidiano. Ela age para a 
câmera e para quem a assiste e essa auto-encenação é seu poder. Mas de que e para que? Estamira deixa de sofrer porque performa? No filme, não. Ela pode enfatizar seu sofrimento, sua reação tempestuosa diante de Deus e dos homens, mas a imagem é de uma mulher amarga, colérica, com raros sorrisos e uma grande tristeza

A performance tem sido caminho mais freqüente, nessa noção particular e restrita no documentário, para a aproximação com as pessoas filmadas. Há uma lógica transformada em consenso segunda a qual é preciso filmar e ouvir de perto para se atravessar as máscaras-barreiras e se chegar à intimidade e à autenticidade do eu posto no alvo da câmera. É questionável a importância dessa dissecação e dessa disseminação dos indivíduos, de seus pensamentos, de suas opiniões e de suas biografias, muitas vezes de seu corpo e de sua pele, como se a revelação de segredos, poros, rugas e zonas de sombra fossem uma conquista em si para o cinema e para o mundo.

Performar seria valoração do sujeito em sua vida, como proprietário de sua vida, detentor dos direitos autorais sobre ela, uma questão de implicações jurídicas, que, se atravanca eventualmente o mercado das biografias não autorizadas, ainda não afetou os documentários sobre os anônimos, ordinários, pobres, desvalidos e outros de classe. Por enquanto, pelo menos. Porque se continuarmos nesse processo não será uma surpresa, mais adiante, que essas pessoas tenham advogados para negociar contratos, deixando de ganhar presentes, gorjetas ou mesadas para receber um salário pelo trabalho, o de performar para a performance do documentário

\section{Intervalo 9: Estamira (a pessoa) é para o que nasce}

Nenhum dos dois documentários centrais na pesquisa teve de mim uma reação imediata positiva ${ }^{26}$. Ambos geraram incômodo. Minha critica sobre $A$ Pessoa é para o que Nasce é centrada na resignação das personagens (as irmãs cegas de Campina Grande, tocadoras de Ganzá, que vivem de esmola) e na auto-propaganda de consciência lavada do filme (que, apesar de dar uma mão às irmãs para ficarem famosas, não as impede de retroceder). Já meu texto sobre Estamira destaca dois pontos pelo menos. Um é a transferência da voz do saber para a voz do empirismo indigente, empregado não como indicialidade de uma sociedade, mas como manifestação de subjetividade, não sem construção estética. Em nome de um mundo visual e sonoro subjetivo de Estamira, o documentário a

\footnotetext{
${ }^{26}$ As críticas de minha autoria, no calor da hora dos lançamentos dos dois filmes, podem ser acessadas na Internet. A de A Pessoa é para o que nasce está em www.contracampo.com.br. A de Estamira, em www. revistacinetica.com.br
} 
elabora, não apenas por suas presenças e falas, mas por uma forma de evidenciá-la e estilizála.

Em outro artigo, mais ensaístico, intitulado "Objetos Sujeitos? ${ }^{27}$, ampliei a questão, colocando os dois documentários em relação, não apenas entre si, mas com um panorama mais extenso de títulos. Nesse texto específico, escrito a partir da experiência de curador da mostra "Eu é um Outro", realizada no Centro Cultural da Caixa em 2008, na qual foram exibidos mais de 30 documentários dos anos 2000, já há um esboço de muitas das questões desenvolvidas na dissertação.

Flash-back, portanto. "Objetos-Sujeitos?" começa com reflexão sobre a transferência da voz de um narrador para uma voz dos personagens, tendo como ponto final da fase anterior (dominada pela voz informativa e interpretativa) a introdução de Notícias de uma Guerra Particular (1999), de João Moreira Salles, coincidentemente exibido pela primeira vez no canal GNT no epílogo do século XX. As novas vozes de locutores, como constato, não informam ou concluem, como antes, dos anos 60 aos 90 , mas apenas lidam com os bastidores do próprio filme, como a de Cabra Marcado para Morrer (1984), de Eduardo Coutinho, que interage com o processo de realização e com as próprias falas internas, ou como a de Extremo Sul (2005), de Monica Schmidt, que fala e pensa sobre o fracasso da própria empreitada.

Isso porque a voz que interessa é da subjetividade, não apenas dos entrevistados, mas também a da voz oficial do filme, encampada na voz do diretor ou de alguém em seu lugar, como é o caso da locução de Santiago (2007), cuja primeira pessoa do diretor é feita por seu irmão. Em outro procedimento, Paula Gaitan em Diário de Sintra (2007), embora fale do lugar de uma subjetividade e de um interior, não diz "eu", assumindo uma primeira pessoa poética, que não precisa se colocar como autobiográfica em nenhuma medida.

Se antes o personagem era um caso ou uma peça dentro de quadro mais amplo, como continua a ser em Ônibus 174 (José Padilha, 2002), O Prisioneiro da Grade de Ferro (Paulo Sacramento, 2002), Meninas (Sandra Werneck, 2006), Sou Feia Mas Tô na Moda (Denise Garcia, 2005), Justiça (Maria Augusta Ramos, 2004), Viva São João (Andrucha Waddington, 2002) e 2000 Nordestes (David França Mendes e Vicente Amorim, 2002), hoje ele é relativizado em sua porção "todo contido na parte". Procura-se nele a presença do que há nele para além dele, mas sem se perder de vista o que há nele somente dele, sua assinatura de vida, seu DNA existencial, sem o qual se mataria o personagem e se reduziria o personagem a uma ilustração - ou, nas palavras de César Guimarães no ensaio O Devir Todo Mundo do Documentário, se deslocaria da diferença irredutível para a inteligibilidade apagadora de diferenças. Em sintonia com o espírito de seu tempo, da crítica mais jovem aos movimentos dramatúrgicos da ficção, persegue-se a autonomia das partes, dos sujeitos, dos personagens, sem necessariamente a mesma procura em direção a se vislumbrar ou se estabelecer relações com um contexto mais amplo dessas existências

\footnotetext{
${ }^{27}$ O ensaio "Objetos-Sujeitos?” pode ser encontrado no arquivo de revistacinetica.com.br
} 
particulares. Essas, quando lá estão, são inevitáveis, não procuradas, quase nunca estabelecidas - o lixão em Estamira (Marcos Prado, 2005), por exemplo. ${ }^{28}$

Na seqüência do artigo, em diálogo com Jean-Louis Commoli ${ }^{29}$, é colocada questão do homem ordinário. Nos documentários, a individualização não solicita, como na publicidade, um espectador/consumidor que se identifique com o personagem, afirmo no texto, mas sim um outro tipo de consumo, interessado na diferença entre espectador e esses personagens, uma diferença afirmada pela condição de margem, invisibilidade e imobilismo, como em A Pessoa É para o Que Nasce (Roberto Berliner, 2003), Moacir - Arte Bruta (Walter Carvalho, 2005) e A Alma do Osso (Cao Guimarães, 2004).

Para Jean-Louis Comolli, no artigo Os Homens Ordinários, A Ficção Documentária, o documentário, longe de ser o território da informação e da categorização, é espaço das metamorfoses, das ambigüidades, daquilo que escapa, em suma, do controle delimitador da câmera. É mais uma presença filmada que uma presença real e do real, uma presença de relações entre quem filma e é filmado. Porém, o sujeito destacado da coletividade foi transformado, em sua exceção espetacular, na norma da massificação, processo ao qual denomina "gozo privado socializado ${ }^{30}$.

No parágrafo seguinte, está em questão a noção de Outro para espectadores e diretores. Queremos nos aproximar, mas com distância, mediados e em segurança, sem nenhum contato direto.

Em quaisquer dos casos, longe de serem os "sujeitos massificados e massificantes", esses personagens, embora possam conter todos em um, embora possam carregar vestígios do universal nas evidências do particular, não são nossos próximos, antes da experiência de contato com eles mediada pelo documentário, mas nossos "outros". Para nos aproximarmos, será necessário, antes de mais nada, curiosidade, ignorância e estranhamento, sem os quais suas presenças perdem em "revelação" (deles e de seus mundos). 0 consumo dessas imagens é o consumo de um pensamento, de uma retórica e de uma experiência da qual, tudo levar a crer, o espectador guarda distância em sua experiência. Quebra-se essa distância no documentário, mas por meio de uma mediação segura, que nos aproxima das imagens e não das pessoas. Não queremos ter a vida deles, sequer fazer o que estão a fazer, mas apenas saber de suas existências, como se expressam, o que pensam, onde e como vivem, sem precisarmos lidar com eles em nossas experiências ${ }^{31}$.

Retomando o diálogo com Comolli, a reflexão lida com a noção de aprisionamento em esquemas e ultrapassamentos desses esquemas, uma possibilidade e uma obrigação ética do documentário, segundo o autor.

\footnotetext{
${ }^{28}$ EDUARDO, Cléber. "Objeto-Sujeito?” In: www.revistacinetica.com.br

${ }^{29}$ COMOLLI, Jean-Louis. "Os Homens Ordinários, a Ficção Documentária". In: O Comum e a Experiência da Linguagem. GUIMARÃES, C.;OTTE, G; SELDLEMAYER, S. Belo Horizonte: UFMG, 2007.

${ }^{30}$ EDUARDO, Cléber. “Objeto Sujeito?” In: revistacinetica.com.br

${ }^{31}$ Idem
} 
Comolli pergunta: os personagens mais singulares não são puro conflito com o mundo, com os outros e consigo mesmos? Filmar é colocar as presenças em relações, mesmo as relações ausentes, porque há relação ao se filmar a não relação, mesmo se for a relação entre quem filma e é filmado. Não existe 0 estar sozinho em um documentário e, quando vemos o ermitão de $A$ Alma do Osso, sozinho consigo e com a natureza, ou mesmo quando assistimos à "solidão pensativa" de Nelson Freire em Nelson Freire (João Moreira Salles, 2003) a deglutir uma "briga" com um piano, estamos diante da performance da solidão, mas não da solidão, porque havia uma câmera ali para filmar essa ausência e para produzir esse efeito do "estar só". Uma presença para produzir ausência.

Comolli fala da relação erótica entre câmera e personagem, relação essa na qual o personagem se torna sujeito ao passar por um ultrapassamento de si, por uma desconexão de seu papel social, como na experiência erótica tal qual pensada por Bataille (morte da consciência). Nesse ultrapassamento, o personagem não se deixa aprisionar pelo controle, menos ou mais evidente, exercido em todo o documentário na relação entre as imagens, palavras e as possibilidades de significados. Torna-se, por zonas de escapes, enigmas. Em alguma medida, selvagens, não domesticados. ${ }^{32}$

Se insisto nas (auto) citações, é porque, nessa introdução da dissertação, acho fundamental, como foi dito no início, um retorno às matrizes do estímulo. Esse artigo em especial lida com algumas observações e questionamentos que formam a base a partir da qual comecei a minha pesquisa e as minhas reflexões mais abrangentes. Neste sentido, parece-me particularmente interessante a recorrência de filmes centrados sobre personagens que podemos chamar de "anônimos extraordinários". Trata-se de seres comuns/ordinários, singularizados tanto por suas retóricas e performances cênicas, assim como por conta de algum tipo de disfunção em suas presenças diante da câmera: deficiência física-orgânicamental, retórica muito peculiar, capacidade de se fazer enigma diante da lente, potência performática singular. Pode ser uma particularidade de condição social - casos dos presidiários de O Prisioneiro da Grade de Ferro, dos suspeitos de infração de Justiça, do protagonista de uma atividade em extinção de Seo Chico - Um Retrato, de jovens em busca de inserção profissional em $P Q D$ (Guilherme Coelho, 2007) -, mas também de condições físicas e mentais, como no caso das cantoras cegas em A Pessoa É para o Que Nasce (acima), da verborragia profética e paranóica em Estamira, da pintura naif e a fala desconexa em Moacir - Arte Bruta. Por que filmar essas pessoas? Como filmá-las? Empregar um olhar sobre elas, assumidamente, ou procurar o olhar delas, ao menos como efeito.

A relação entre o eu que filma e o outro que é filmado não pode ser considerada uma simples relação direta entre um sujeito e seus objetos humanos. Há da parte do objeto uma parcela de sua presença como sujeito em determinadas circunstâncias - em Edifício Master, por exemplo - e da parte do sujeito à disposição de se tornar também objeto em alguns casos - em $A$ Pessoa É para o Que Nasce. De qualquer forma, quando uma câmera é dirigida para alguém, há um exercício de poder, queira o realizador ou não, em relação a quem está em quadro. Não há como se fugir disso, como se esse

\footnotetext{
${ }^{32}$ Ibidem
} 
poder fosse em si nefasto ou deturpador da imagem de quem está enquadrado, até porque essa imagem do outro, a rigor, será construída nessa relação. ${ }^{33}$

Para encerrar o diálogo com esse artigo, cito apenas mais dois parágrafos, pois lidam com algo também caro ao projeto, que é a noção de ética, moral e abjeção na análise crítica dos documentários, tendo em vista que, em vez de estarmos diante de imagens de pessoas que interpretam para gerar imagens, como na ficção, os seres filmados, mesmo em processo de auto-ficção ${ }^{34}$, são seres que, fora da tela, permanecem na vida. Não se quer com isso estabelecer dogmas e interdições a temas e circunstâncias filmáveis ou não, transformando o documentário em uma zona de solo minado onde não se pode colocar o pé sem pedir a benção a Deus, aos entrevistados e a todos os críticos fundamentalistas em seus ataques a operações consideradas imorais, mas, por outro lado, também não se quer partir do pressuposto de que o cinema de modo geral e o documentário de modo específico podem tudo, criando assim uma outra zona, a da banalização das imagens e dos procedimentos, a da aceitação generalizada, conforme constataram e alertaram Jacques Rivette ${ }^{35}$ e Serge Daney $^{36}$.

Ao pensarmos a imagem do homem anônimo no documentário, talvez, tenhamos de arquivar todas as proibições morais. Pensemos somente em uma ética na estética documental, que não é lei para o documentário, mas produto da própria obra já finalizada, que não se determina como regra, mas se intui ou se demonstra pelas próprias características na tela. Uma moral talvez pudesse proibir documentaristas de filmar pessoas com deficiências mentais ou físicas. Uma ética só seria construída a partir das escolhas do documentarista ao filmar pessoas nessas condições. Não antes.

Ao pensarmos uma ética e uma instância autoral quando estamos diante de imagens de homens e mulheres comuns, no fundo, estamos atrás de legitimação e questionamento sobre maneiras de filmar esses homens e mulheres, atrás de um suposto certo e errado em cada caso, atrás dos possíveis e supostos limites ao se exercer o poder da câmera sobre aquelas figuras humanas destituídas de poder para se afirmarem como imagens públicas. No entanto, como lidar com esse trabalho inevitavelmente dotado de certa carga de patrulha e fiscalização, mais forte no documentário, se os próprios documentaristas, segundo seus procedimentos, procuram um espaço de desregulação e liberdade, com menos regras e menos limites para poder lidar com seus materiais? Talvez faça parte dessa maior liberdade a fuga do homem e da mulher simples como indicialidade sintomática de povo brasileiro ou de classe social. Procura-se pessoas e não representantes do povo. Procura-se o único, o singular, o inigualável, o extraordinário do ordinário, não o homem médio e medíocre, o homem exemplar, capaz de carregar a estrutura em si mesmo. Procura-se as zonas de escape e de fuga, as exceções, o lado especial de uma gente sem lugar de destaque. ${ }^{37}$

Não estamos diante de objetos artísticos situados em alta consideração pelo juízo crítico (o meu, ao menos), mas diante de documentários com os quais eventualmente

\footnotetext{
${ }^{33}$ Ibidem

${ }^{34}$ Para ler mais respeito sobre "auto-ficção", sugiro a leitura de uma série de posts no blog de JeanClaude Bernardet no portal www.uol.com.br

${ }^{35}$ RIVETTE, Jacques. "De l'a abjection”. In: Cahiers Du Cinema, no 120. Paris, 1961

${ }^{36}$ DANEY, Serge. "Travelling de Kapo". In: Traffic, 1992.

${ }^{37}$ EDUARDO, Cleber. “Objetos Sujeitos?” In: www.revistacinetica.com.br
} 
brigamos, diante dos quais nos colocamos em dúvida sobre as razões de nossa briga, que se constituem como problemas a serem destrinchados, sem necessariamente serem resolvidos após a jornada de análise e pesquisa no interior deles e no entorno dos mesmos. Esse entorno é crucial. Como já foi colocado, a crítica, em sua prática e em seus recortes, não deve agir apenas com lupas, mas também usar telescópios. Não pode acionar apenas o zoon in para os planos-detalhes sem também se distanciar para um quadro mais aberto, em perspectiva e com profundidade de campo, articulando o plano-sequência bazaniano com a montagem de atração de Eisenstein. Uma proximidade excessiva com os filmes, um mergulho em seus fotogramas apenas, sem recuo posterior, pode resultar em processo apenas descritivo e de amalgamento com a obra, quando o crítico só se constitui por sua capacidade de por em relação os miúdos. 


\section{Epílogo: a performance estética}

Estamira e A pessoa é para o que nasce começam de formas bem distintas. Memm com clima situado entre o mistério e a tensão, estimulado pela trilha sonora instrumental, pontuado pelo canto choroso e gritado de uma mulher, com uma sonoridade possível de ser encontrado em um filme árabe. O outro com música quase sacra, sentimental, que procura a sedução pela compaixão.

Em Estamira, com imagens em preto e branco granuladas, estilizadas, vemos um casa por fora e planos detalhes de elementos circundantes, como garrafa velha, chaleira, uma bacia com água parada, um cachorro, um fogão no interior da casa. Rastros de um mundo precário, de abandono, que o filme mostra, sem querer olhar.

São planos de dois a três segundos, dinâmica mantida até a aparição de Estamira, aos dois minutos, de costas, ainda com a imagem em preto e branco, ela a se distanciar da câmera. Estamira espera um ônibus, ainda de costas, e, ao entrar, logo veremos seus olhos, sua pele, câmera colada. No caminho do ônibus ao Jardim Gramacho, o aterro sanitário para onde se dirige, a câmera enquadra o tique nas mãos, já um primeiro sinal evidenciado como "anormal".

A pessoa é para o que nasce lança de um colorido forte e, depois de vermos três mulheres à distância sendo conduzidas por outra, assistiremos elas acordando em seu quarto, onde duas dividem uma cama. Percebe-se que são cegas, pela dificuldade em se vestirem, mas parecem harmônicas.

Se em Estamira a câmera é indiscreta, encurtando a distância inicial para quase entrar em seus poros e depois ficar de olho em seu movimento de dedos (primeiro sinal de sua "anormalidade"), em A pessoa é para o que nasce essa indiscrição se manifesta, de cara, na decisão de registrá-las acordando, à procura de uma intimidade.

Os momentos seguintes dos dois filmes nos apresentam as personagens. Estamira insiste na opção pela descrição ligeira do espaço, agora o Jardim Gramacho, aterro sanitário onde a protagonista trabalha. Ainda em preto e branco granulado, 
oscilando planos distantes dela a caminho do lixão em uma estrada de terra, o filme evita nos dar seu rosto.

Somente após trocar de roupa, de tecidos gastos por outros piores, veremos sua expressão, vestida para catar restos, com uma toca na cabeça. É uma trabalhadora, mas, pela forma com que a sucessão de imagens a mostra, progressivamente, às vezes excedendo a proximidade com partes do corpo (olho, mãos), algo frequente no filme, essa mulher torna-se figura de terror.

Será contrária essa apresentação em A pessoa é para o que nasce. Após o amanhecer com as três no quarto, elas se apresentam, lado a lado, sentadas, posadas, e tanto falam seus nomes como seus apelidos, pelos quais uma trata a outra o tempo todo: Maroca, Poroca e Indaiá. Cada uma delas, ao falar, conta de si. São graciosas, simpáticas, cativantes. Figuras fáceis de se gostar e com as quais se compadecer.

Estamira é o oposto. Ao falar pela primeira vez, expressão séria, sem humor (ausência constante), coloca um peso em sua existência. Sua missão, diz, é revelar a verdade. Não se trata de uma religiosa, muito pelo contrário, mas de uma messiânica apolalíptica, no entanto sem seguidores, assim como sem crenças. Ela logo se apresentará com uma força equivalente à natureza, gesticulando com vento, fogo, raio. O aterro é coisa boa, ela não chama de lixo. Faz tudo por opção.

Os dois filmes lidam com as personagens de formas muito distintas. Além da ausência de cores em um, quebrada inicialmente apenas após ela se vestir para trabalhar, e do forte colorido no outro, o ritmo inicial também os distancia. Estamira é fragmentado, ansioso, seus planos mal informam, não observam. A pessoa é para o que nasce dá mais tempo às situações. Talvez possamos dizer que, por conta do tempo de acompanhamento das personagens, muita coisa acontece, mas não se acelera

Há um disposição, ao longo de boa parte de Estamira, de encadear retalhos visuais, separando os pensamentos da protagonista das muitas imagens, não exatamente organizadas dentro de um esquema gerador de sentidos, mas multiplicadas em um fluxo de uma mono-tonia maximizante. $\mathrm{O}$ filme trabalha sempre na intensificação (de efeitos estilizados, de gritos, de música). 
Essa aproximação pelas diferenças é apenas uma forma de colocarmos algumas particularidades entre os dois filmes nesse início, algumas delas mantidas até o final, no entanto, são fortes os elementos a unir essas personagens e os dois filmes. Ambos lidam com mulheres que vivem dos restos ou excessos alheios, uma no aterro, as irmãs cantando na rua em troca de trocados. Se uma será diagnosticada pelos filhos e por documentos médicos como esquisofrênica, as três irmãs vivem na dependência de outros por não enxergarem.

Estamira ao longo do filme briga com a família, conta um pouco de seu passado e, embora se coloque como forte, onisciente e onipresente, não deixa de se apresentar também como vítima do mundo, com traumas de perdas e com consciência de uma humanidade a manipular tudo, menos ela, que sabe disso e não se deixa apanhar. Importante observar que Estamira gosta de sua vida, do lixo, de quem ela é.

Maroca, Poroca e Indaía, se não têm a retórica de poder e resistência de Estamira, se tiveram várias perdas, se ficaram famosas e voltaram a mendigar, se dizem mais de uma vez que a pessoa é para o que nasce, aproximam-se de Estamira justamente por essa performance da satisfação.

Os dois filmes também performam esteticamente e procuram encontrar imagens para as personagens, com uma ambição de expressar pela forma a interioridade das pessoas filmadas. Ambos ainda se valem da rentabilização cênica e narrativa para, em meio a tantas carências e sofrimentos dessas mulheres, obterem um superávit fílmico e, assim, talvez, emprestarem algo desse rendimento para cada uma delas.

Uma estratégia politicamente questionável, se não esvaziante, que não se indigna com nada e, ainda por cima, nos oferta certa satisfação de colocarem elas em imagem, dando-lhes uma presença midiática efêmera, que procura abafar a cruel situação exposta com perfume e beleza obtida na finalização. 
ANEXOS 


\section{ANEXO I}

Listas de melhores filmes brasileiros da década. Em destaque, os documentários:

\begin{tabular}{|c|l|}
\hline & \multicolumn{1}{|c|}{ O GLOBO } \\
\hline $1^{\circ}$ & "Cidade de Deus", de Fernando Meirelles \\
\hline $2^{\circ}$ & "Edifício Master", de Eduardo Coutinho \\
\hline $3^{\circ}$ & "Tropa de elite", de José Padilha \\
\hline $4^{\circ}$ & "O invasor", de Beto Brant \\
\hline $5^{\circ}$ & "Cinema, aspirinas e urubus", de Marcelo Gomes \\
\hline $6^{\circ}$ & "Estômago", de Marcos Jorge \\
\hline $7^{\circ}$ & "Serras da desordem", de Andrea Tonacci \\
\hline $8^{\circ}$ & "O cheiro do ralo", de Heitor Dhalia \\
\hline $9^{\circ}$ & "Lavoura arcaica", de Luiz Fernando Carvalho \\
\hline $10^{\circ}$ & "Ônibus 174", de José Padilha \\
\hline
\end{tabular}

Votantes: André Miranda eu, Alberto Shatovsky, Arnaldo Bloch, Arthur Dapieve, Érico Reis, Gustavo Leitão, Marcelo Janot, Miguel Pereira, Pedro Butcher e Rodrigo Fonseca).

*Outros 42 filmes foram lembrados pelo menos uma vez pelo júri. São eles:

Documentários: "500 almas", "Estamira", "Fabricando Tom Zé", "Garapa", "Glauber, o filme - Labirinto do Brasil", "Janela da alma", "Jogo de cena", "Nelson Freire", "Santiago", e "Vinicius".

Ficção: "Abril despedaçado", "Amarelo manga", "Apolônio Brasil", "Auto da compadecida", "Bicho de sete cabeças", "Boleiros 2", "Cão sem dono", "Carandiru", "O céu de Suely", "Chega de saudade", "Cidade Baixa", "Crime delicado", "Desmundo", "Dias de Nietzsche em Turim", "Ensaio sobre a cegueira", "Estorvo", "Eu me lembro", "Eu tu eles", "Falsa loura", "Filme de amor", "O homem que copiava", "Houve uma vez dois verões", "Linha de passe", "Lost Zweig", "Madame Satã", "Meu nome não é Johnny", "Moscou", "Narradores de Javé", "O passado", "O príncipe", "Quase dois irmãos" e "Separações". 


\begin{tabular}{|c|l|}
\hline & \multicolumn{1}{|c|}{ BRAVO } \\
\hline $1^{\circ}$ & "Jogo de Cena", de Eduardo Coutinho \\
\hline $2^{\circ}$ & "Lavoura Arcaica", de Luiz Fernando Carvalho \\
\hline $3^{\circ}$ & "Santiago", de João Moreira Salles \\
\hline $4^{\circ}$ & "Cidade de Deus", de Fernando Meirelles \\
\hline $5^{\circ}$ & "Viajo porque preciso. Volto porque te amo", de Marcelo Gomes e Karim Aïnouz \\
\hline
\end{tabular}

\begin{tabular}{|l|}
\hline \multicolumn{1}{|c|}{ TOP 10 } \\
\hline Cidade de Deus (2002), de Fernando Meirelles \\
\hline O invasor (2001), de Beto Brant \\
\hline Cinema, aspirinas e urubus (2005), de Marcelo Gomes \\
\hline Jogo de Cena, de Eduardo Coutinho \\
\hline Serras da desordem (2006), de Andréa Tonacci \\
\hline Santiago (2008), de João Moreira Salles \\
\hline Lavoura arcaica (2001), de Luiz Fernando Carvalho \\
\hline Madame Satã (2002), de Karim Aïnouz \\
\hline Edifício Máster (2002), de Eduardo Coutinho \\
\hline Amarelo manga (2003), de Cláudio Assis \\
\hline
\end{tabular}

Os votantes: André Setaro, André Sturm, Andréa França, Anna Muylaert, Arthur Autran, Cao Guimarães, Carlos Alberto de Mattos, Carlos Ebert, Carlos Eduardo Rodrigues, Carlos Gerbase, Cezar Migliorin, Cleber Eduardo, Daniel Caetano, Denílson Lopes, Edgar Moura, Eduardo Escorel, Eduardo Valente, Esmir Filho, Evaldo Mocarzel, Fernando Mascarello, Fernando Meirelles, Francis Vogner dos Reis, Guilherme de Almeida Prado, Hermes Leal, Hernani Heffner, Humberto Pereira da Silva, Inácio Araújo, Ivo Lopes Araújo, Ivonete Pinto, Jean Claude Bernardet, Jean Thomas Bernardini, João Batista de Andrade, Jorge Duran, José Geraldo Couto, Julio Bezerra, Lírio Ferreira, Lúcia Murat, Luiz Zanin, Marcelo Janot, Marcos Jorge, Marcus 
Mello, Paulo Halm, Pedro Butcher, Philippe Barcinski, Roberto Farias, Rogério Luz, Rosário Caetano, Ruy Gardnier, Sérgio Alpendre, Sérgio Machado, Sérgio Sanz, Sílvio Da-Rin, Tatiana Monassa, Toni Venturi, Walbercy Ribas, Walter Carvalho e Vladimir Carvalho.

\section{ANEXO II}

Participação de documentários brasileiros nos principais festivais internacionais entre 2000 e 2010

Fonte: Catálogo da mostra Cinema Brasileiro anos 2000, 10 questões (2011)

\begin{tabular}{|c|c|}
\hline & CANNES \\
\hline 2004 & Glauber, o filme, de Silvio Tendler (fora de competição) \\
\hline
\end{tabular}

\begin{tabular}{|l|l|}
\hline & \multicolumn{1}{|c|}{ VENEZA } \\
\hline 2002 & Rocha que voa, de Erych Rocha (mostra Novas Territórios) \\
\hline 2007 & Andarilho, de Cao Guimarães (mostra Orizzonti) \\
\hline 2007 & Anabazys, de Joel Pizzini e Paloma Rocha (sessão Especial) \\
\hline
\end{tabular}

\begin{tabular}{|l|l|}
\hline & \multicolumn{1}{|c|}{ BERLIM } \\
\hline 2004 & Fala Tu, de Guilherme Coelho (sessão Panorama) \\
\hline 2006 & Meninas, de Sandra Werneck (mostra Panorama) \\
\hline 2006 & Atos dos Homens (mostra Fórum) \\
\hline 2009 & Garapa (sessão Panorama) \\
\hline 2010 & Lixo Extraordinário (sessão Panorama) \\
\hline
\end{tabular}

\begin{tabular}{|l|l|}
\hline 2001 & $\begin{array}{l}\text { ROTERDÃ } \\
\text { O Rap do Pequeno Príncipe contra as almas sebosas, de Paulo Caldas e Marcelo } \\
\text { Luna }\end{array}$ \\
\hline
\end{tabular}




\begin{tabular}{|l|l|}
\hline 2002 & Onde a terra acaba, de Sergio Machado \\
\hline 2003 & Onibus 174, de José Padilha \\
\hline 2005 & Estamira, de Marcos Prado \\
\hline 2007 & Acidente, de Cao Guimarães \\
\hline 2008 & Andarilho, de Cao Guimarães \\
\hline 2008 & Juizo, de Maria Augusta Ramos \\
\hline 2009 & Acácio, de Marilia Franco \\
\hline 2010 & A falta que me faz, de Marilia Rocha \\
\hline 2010 & Belair, de Bruno Safadi \\
\hline 2010 & Avenida Brasília Formosa, de Gabriel Mascaro \\
\hline
\end{tabular}

\begin{tabular}{|l|l|}
\hline & \multicolumn{1}{|c|}{ SUNDANCE } \\
\hline 2003 & Ônibus 174, de José Padilha \\
\hline 2005 & Soy Cuba, de Vicente Ferraz \\
\hline 2007 & Acidente, de Cao Guimarães \\
\hline 2010 & Lixo Extraordinário, de João Jardim, Lucy Walker, Karen Harley \\
\hline 2010 & Segredos da Tribo, de José Padilha \\
\hline
\end{tabular}

\begin{tabular}{|l|l|}
\hline & \\
\hline 2002 & Rocha que Voa, de Eryk Rocha \\
\hline 2002 & 33, de Kiko Goifman \\
\hline 2004 & Mesageiras da Luz, de Evaldo Mocarzel \\
\hline 2004 & Rua de mão dupla, de Cao Guimarães \\
\hline 2005 & Soy Cuba, de Vicente Ferraz \\
\hline 2006 & Acidente, de Cao Guimarães \\
\hline 2006 & Person, de Marina Person \\
\hline
\end{tabular}




\begin{tabular}{|l|l|}
\hline 2007 & Juizo, de Maria Augusta Ramos \\
\hline 2007 & Moacir Arte Bruta, de Walter Carvalho \\
\hline 2008 & Jogo de Cena, de Eduardo Coutinho \\
\hline 2008 & Andarilho, de Cao Guimarães \\
\hline 2008 & Estrada Real da Cachaça, de Pedro Urano \\
\hline
\end{tabular}

\section{ANEXO III}

Participação brasileira no É Tudo Verdade e presença de documentários estrangeiros nos principais festivais internacionais.

\begin{tabular}{|c|c|c|c|}
\hline Festival & Ano & Filme & Status do filme \\
\hline \multirow[t]{16}{*}{ É Tudo Verdade } & 1997 & $\begin{array}{l}\text { Antártida, O Último Continente, de } \\
\text { Monica Schmiedt e Alberto Savá }\end{array}$ & Em competição \\
\hline & & $\begin{array}{l}\text { Bahia de Todos os Sambas, de Paulo } \\
\text { Cazar Saracini e Leon Hirszman }\end{array}$ & Em competição \\
\hline & & $\begin{array}{l}\text { Brasília, Um Dia em Fevereiro, Maria } \\
\text { Augusta Ramos }\end{array}$ & Em competição \\
\hline & & $\begin{array}{l}\text { Brevíssima História das Gentes de } \\
\text { Santos, de André Klotzel }\end{array}$ & Em competição \\
\hline & & Burro sem Rabo, de Sérgio Bloch & Em competição \\
\hline & & $\begin{array}{l}\text { O Capeta Caribé, de Agnaldo Siri } \\
\text { Azevedo }\end{array}$ & Em competição \\
\hline & & $\begin{array}{l}\text { Mamazônia, a Última Floresta, de Celso } \\
\text { Luccas e Brasília Mascarenhas }\end{array}$ & Em competição \\
\hline & & $\begin{array}{l}\text { O Velho - A História de Luiz Carlos } \\
\text { Prestes, de Toni Venturi }\end{array}$ & Vencedor \\
\hline & & $\begin{array}{l}\text { Terra do Mar, de Mirella Martinelli, } \\
\text { Eduardo Caron }\end{array}$ & Em competição \\
\hline & & Zweig: A Morte em Cena, de Sylvio Back & Em competição \\
\hline & 1998 & $\begin{array}{l}\text { Will Eisner Profissão Cartunista - } \\
\text { Episódios Spirit, O Sonho e Master } \\
\text { Class, de Marisa Furtado de Oliveira }\end{array}$ & Em competição \\
\hline & & $\begin{array}{l}\text { À Meia Noite com Glauber, de Ivan } \\
\text { Cardoso }\end{array}$ & Em competição \\
\hline & & Caminho das Onças, de Sérgio Sanz & Em competição \\
\hline & & Coração do Brasil, de João Facó & Em competição \\
\hline & & Geraldo Filme, de Carlos Cortez & Em competição \\
\hline & & $J K$, de Luciana Canton & Em competição \\
\hline
\end{tabular}




\begin{tabular}{|c|c|c|c|}
\hline & & Nelson Sargento, de Estevão Pantoja & Em competição \\
\hline & & O Cineasta da Selva, de Aurélio Michiles & Em competição \\
\hline & & O Vidreiro, de Marcos de Souza Mendes & Em competição \\
\hline & & $\begin{array}{l}\text { Recife de Dentro para Fora, de Kátia } \\
\text { Mesel }\end{array}$ & Em competição \\
\hline & 1999 & $\begin{array}{l}\text { A Pessoa é para o que Nasce, de Roberto } \\
\text { Berliner }\end{array}$ & Vencedor \\
\hline & 2000 & $\begin{array}{l}\text { Ao Sul da Paisagem: "Paisagem e } \\
\text { Memória", de Paschoal Samora }\end{array}$ & Em competição \\
\hline & & $\begin{array}{l}\text { Fawcett - O Enigma de Um Explorador, } \\
\text { de Alfeu França, Bernardo Brik, Gustavo } \\
\text { Duarte e Leonardo Lassance }\end{array}$ & Em competição \\
\hline & & $\begin{array}{l}\text { Maldito - O Estranho Mundo de José } \\
\text { Mojica Marins, de } \\
\text { André Barcinski e Ivan Finotti }\end{array}$ & Vencedor \\
\hline & & $\begin{array}{l}\text { Gilbertianas, de } \\
\text { Ricardo Miranda }\end{array}$ & Em competição \\
\hline & & $\begin{array}{l}\text { Laurindo Almeida, Muito Prazer, } \\
\text { Leonardo Dourado }\end{array}$ & Em competição \\
\hline & & $\begin{array}{l}\text { Notícias de Uma Guerra Particular, de } \\
\text { João Moreira Salles e Kátia Lund }\end{array}$ & Em competição \\
\hline & & $\begin{array}{l}\text { O Rap do Pequeno Príncipe Contra as } \\
\text { Almas Sebosas, de } \\
\text { Paulo Caldas e Marcelo Luna }\end{array}$ & Em competição \\
\hline & & $\begin{array}{l}\text { Oriki, de } \\
\text { Jorge Alfredo e Moisés Augusto }\end{array}$ & Em competição \\
\hline & & $\frac{\text { Os Carvoeiros, }}{\text { Nigel Noble }}$ & Em competição \\
\hline & & $\begin{array}{l}\text { Passadouro, de } \\
\text { Torquato Joel }\end{array}$ & Em competição \\
\hline & & $\begin{array}{l}\text { Santo Forte, de } \\
\text { Eduardo Coutinho }\end{array}$ & Em competição \\
\hline & & $\frac{\text { Sobras em Obras }}{\text { Michel Favre }}$ de & Em competição \\
\hline & & $\begin{array}{l}\text { Walter Franco Muito Tudo, de } \\
\text { Bel Bechara e Sandro Serpa }\end{array}$ & Em competição \\
\hline & 2001 & A Negação do Brasil, de Joel Zito Araújo & Em competição \\
\hline & & $\begin{array}{l}\text { Ao Sul da Paisagem-Paisagens } \\
\text { Invisíveis, de Paschoal Samora }\end{array}$ & Em competição \\
\hline & & Carrego Comigo, de Chico Teixeira & Em competição \\
\hline & & $\begin{array}{l}\text { Glauces - Estudo de um rosto, de Joel } \\
\text { Pizzini }\end{array}$ & Em competição \\
\hline & & Julliu's Bar, de Consuelo Lins & Em competição \\
\hline & & Malagrida, de Renato Barbieri & Em competição \\
\hline & & O Fim do Sem Fim, de Lucas Bambozzi, & Em competição \\
\hline
\end{tabular}




\begin{tabular}{|c|c|c|c|}
\hline & & Beto Magalhães \& Cao Guimarães & \\
\hline & & Olho da Rua, de Sérgio Bloch & Em competição \\
\hline & & $\begin{array}{l}\text { Onde a Coruja Dorme, de Márcia } \\
\text { Derraik e Simplício Neto }\end{array}$ & Em competição \\
\hline & & $\begin{array}{l}\text { Presente dos Deuses, de Andréa França e } \\
\text { Ana Teresa Reynaud }\end{array}$ & Em competição \\
\hline & & Seu Nenê, de Carlos Cortez & Em competição \\
\hline & & $\begin{array}{l}\text { A Composição do Vazio, de Marcos } \\
\text { Enrique Lopes }\end{array}$ & Em competição \\
\hline & 2006 & $\begin{array}{l}\text { À Margem do Concreto, de Evaldo } \\
\text { Mocarzel }\end{array}$ & Em competição \\
\hline & & Atos dos Homens, de Kiko Goifman & Em competição \\
\hline & & Caparaó, de Flavio Frederico & Vencedor \\
\hline & & $\begin{array}{l}\text { Deus e o Diabo em Cima da Muralha, de } \\
\text { Tocha Alves e Daniel Lieff }\end{array}$ & Em competição \\
\hline & & $\begin{array}{l}\text { Dia de Festa, de Toni Venturi e Pablo } \\
\text { Georgieff }\end{array}$ & Em competição \\
\hline & & Diário de Naná, de Paschoal Samora & Em competição \\
\hline & & Dona Helena, de Dainara Toffoli & Em competição \\
\hline & & $\begin{array}{l}\text { Herbert de Perto, de Roberto Berliner e } \\
\text { Pedro Bronz }\end{array}$ & Em competição \\
\hline & & O Profeta das Águas, de Leopoldo Nunes & Em competição \\
\hline & & $\begin{array}{l}\text { Pixote in Memoriam, de Felipe Briso e } \\
\text { Gilberto Topczewski }\end{array}$ & Em competição \\
\hline & 2007 & Construção, de Cristiano Burlan & Em competição \\
\hline & & $\begin{array}{l}\text { Descaminhos, de Marília Rocha, Luiz } \\
\text { Felipe Fernandes etc. }\end{array}$ & Em competição \\
\hline & & $\begin{array}{l}\text { Elevado 3.5, de João Sodré, Maíra Bühler } \\
\text { e Paulo Pastorelo }\end{array}$ & Vencedor \\
\hline & & $\begin{array}{l}\text { Lutzenberger: For Ever Gaia, de Frank } \\
\text { Coe e Otto Guerra }\end{array}$ & Em competição \\
\hline & & $\begin{array}{l}\text { Maria Bethânia - Pedrinha de Aruanda, } \\
\text { de Andrucha Waddington }\end{array}$ & Em competição \\
\hline & & $\begin{array}{l}\text { Nas Terras do Bem-Virá, de Alexandre } \\
\text { Rampazzo }\end{array}$ & Menção honrosa \\
\hline & 2008 & $\begin{array}{l}\text { Dia dos Pais, de Julia Murat e Leonardo } \\
\text { Bittencourt }\end{array}$ & Em competição \\
\hline & & $\begin{array}{l}\text { João, de André Iki Siqueira e Beto } \\
\text { Macedo }\end{array}$ & Em competição \\
\hline & & $\begin{array}{l}\text { Pan-Cinema Permanente, de Carlos } \\
\text { Nader }\end{array}$ & Vencedor \\
\hline & & O Aborto dos Outros, de Carla Gallo & Menção honrosa \\
\hline & & O Tempo e o Lugar, de Eduardo Escorel & Em competição \\
\hline & & $\begin{array}{l}\text { Simonal - Ninguém Sabe o Duro que Dei, } \\
\text { de Claudio Manoel, Micael Langer e } \\
\text { Calvito Leal }\end{array}$ & Menção honrosa \\
\hline & & Sumidouro, de Cris Azzi & Em competição \\
\hline & & O Longo Amanhecer-Cinebiografia de & Menção honrosa \\
\hline
\end{tabular}




\begin{tabular}{|c|c|c|c|c|}
\hline & & Celso Furtado, de José Mariani & & \\
\hline & 2009 & A Chave de Casa, de Paschoal Samora & Em competição & \\
\hline & & Cidadão Boilensen, de Chaim Litewski & Vencedor & \\
\hline & & Cildo, de Gustavo Rosa de Moura & Em competição & \\
\hline & & Corumbiara, de Vincent Carelli & Menção honrosa & \\
\hline & & Garapa, de José Padilh & Em competição & \\
\hline & & Moscou, de Eduardo Coutinho & Em competição & \\
\hline & & $\begin{array}{l}\text { Sobreviventes, de Miriam Chnaiderman e } \\
\text { Reinaldo Pinheiro }\end{array}$ & Em competição & \\
\hline & 2010 & $\begin{array}{l}\text { Arquitetos do Poder, de Vicente Ferraz e } \\
\text { Alessandra Aldé }\end{array}$ & Em competição & \\
\hline & & $\begin{array}{l}\text { Eu, o Vinil e o Resto do Mundo, de Lila } \\
\text { Rodrigues, Karina Ades }\end{array}$ & Em competição & \\
\hline & & $\begin{array}{l}\text { Terra Deu, Terra Come, de Rodrigo } \\
\text { Siqueira }\end{array}$ & Vencedor & \\
\hline & & $\begin{array}{l}\text { Fora de Campo, de Adirley Queirós. } \\
\text { Thiago Mendonça }\end{array}$ & Em competição & \\
\hline & & $\begin{array}{l}\text { O Contestado-Restos Mortais, de } \\
\text { Sylvio Back }\end{array}$ & Em competição & \\
\hline & & Os Representantes, de Felipe Lacerda & Em competição & \\
\hline & & $\begin{array}{l}\text { Programa Casé - O que a Gente Não } \\
\text { Inventa, Não Existe, de Estevão Ciavatta }\end{array}$ & Em competição & \\
\hline & 2011 & Assim É, Se lhe Parece, de Carlha Gallo & Em competição & \\
\hline & & $\begin{array}{l}\text { Aterro do Flamengo, de Alessandra } \\
\text { Bergamaschi }\end{array}$ & Menção honrosa & \\
\hline & & $\begin{array}{l}\text { Carne, Osso, de Caio Cavechini e Carlos } \\
\text { Juliano Barros }\end{array}$ & & \\
\hline & & $\begin{array}{l}\text { Dois Tempos, de Arthur Fontes, Dorrit } \\
\text { Harazim }\end{array}$ & Vencedor & \\
\hline & & Tancredo, a Travessia, de Silvio Tendler & Em competição & \\
\hline & & Vale dos Esquecidos, de Maria Raduan & Em competição & \\
\hline & & $\begin{array}{l}\text { Vocacional, Uma Aventura Humana, de } \\
\text { Toni Venturi }\end{array}$ & Em competição & \\
\hline Cannes & 2002 & Tiros em Columbine, de Michael Moore & Vencedor & O cul \\
\hline & 2004 & Fahrenheit 9/11, de Michael Moore & Vencedor & $\begin{array}{l}\text { O filn } \\
\text { a fars } \\
\text { invase }\end{array}$ \\
\hline & & Mondovino, de Jonathan Nossiter & Em competição & O imp \\
\hline Berlim & 2003 & Nesse Mundo, Michael Winterbottom & Vencedor & $\begin{array}{l}\text { A sag } \\
\text { fronte } \\
* \text { não }\end{array}$ \\
\hline \multirow[t]{3}{*}{ Cinéma du Réel } & 2003 & - & - & $\begin{array}{l}\text { Eduar } \\
\text { intern }\end{array}$ \\
\hline & 2007 & Santiago (2006), de João Moreira Salles & $\begin{array}{c}\text { Vencedor do Grand } \\
\text { Prix Cinéma Du } \\
\text { Réel }\end{array}$ & \\
\hline & & $\begin{array}{l}\text { Saba (2006), de Thereza Menezes e } \\
\text { Gregório Graziosi }\end{array}$ & Em competição & \\
\hline
\end{tabular}




\begin{tabular}{|c|c|l|l|l|}
\hline & 2010 & $\begin{array}{l}\text { Viajo Porque Preciso, Volto Porque te } \\
\text { Amo, de Marcelo Gomes e Karim Aïnouz }\end{array}$ & Em competição & \\
\hline FID Marseille & 2003 & Edifício Master, de Eduardo Coutinho & & \\
\hline & 2005 & Estamira, de Marcos Prado & & \\
\hline & 2006 & O Fim e o Pincípio, de Eduardo Coutinho & & \\
\hline & 2008 & Juízo, de Maria Ramos & & \\
\hline & 2010 & $\begin{array}{l}\text { Chantal Akerman, de Cá, de Gustavo } \\
\text { Beck e Leonardo Luiz Ferreira }\end{array}$ & & \\
\hline
\end{tabular}




\section{Referências bibliográficas}

ADORNO, Theodor. "O ensaio como forma". In: Notas de Literatura I. São Paulo: Editora 34 e Duas Cidades, 2003.

AGAMBEN, Giorgio. O que é o contemporâneo? e outros ensaios. Chapecó, SC: Argos, 2009.

AZEREDO, Ely. Olhar crítico - 50 anos de cinema brasileiro. São Paulo: Instituto Moreira Salles, 2009.

BAKHTIN, Mikhail. Marxismo e filosofia da linguagem. São Paulo: HUCITEC, 2009. Estética da Criação Verbal. São Paulo: Martins Fontes, 1992. Questões de Literatura e de Estética. São Paulo: Ed Unesp, 1998

BALTAR, Mariana. "Cotidianos em performance: Estamira encontra as mulheres de Jogo de cena. In: MIGLIORIN, Cezar (org.) Ensaios no real. Rio de Janeiro: Azougue, 2010.

BARTHES, Roland. "A morte do autor”. In: O rumor da língua. São Paulo: Martins Fontes, 2004.

BRAIT, Beth (org.). Bakhtin, dialogismo e construção do sentido. Campinas, SP: Editora da UNICAMP, 2005.

BERNARDET, Jean-Claude. Cineastas e imagens do povo. São Paulo: Cia. das Letras, 2003.

Paulo: 1979-1980.

A Voz do Outro. In: NOVAES, Adauto (Org.). Anos 70. Cinema. São

BEZERRA, Paulo. Polifonia. In: BRAIT, Beth (Org.). Bakhtin, conceitos-chave. São Paulo: Contexto, 2005.

BUBER, Martin. Do diálogo e do dialógico. São Paulo: Perspectiva, 1982. . Eu e Tu. São Paulo: Centauro, 2003.

BURKE, Peter. Testemunha ocular - história e imagem. Bauru, SP: EDUSC, 2004. 
BONITZER, Pascal. Les silences de la voix. Cahiers du Cinema, n 256, fev-mar 1975.

CAIXETA, Rubens; GUIMARÃES, Cesar. "Pelo destino entre ficção e documentário, provisoriamente". In COMMOLI, Jean-Louis. Ver e Poder - A inocência perdida: cinema, televisão, ficção, documentário. Belo Horizonte: UFMG, 2008.

CANETTI, Elias. Massa e poder. São Paulo: Cia das Letras, 2005.

CHION, Michel. La loz em el cine. Madrid: Ed Catedra, 2004

CIANCIO, Maria Belém. "Entre films, trance y filosofia: Gilles Deleuze y el nuevo cine latinoamericano. In: Secuencias - Revista de Historia del Cine, $1^{\circ}$ semestre 2010, Universidad Autónoma de Madrid.

COMOLLI, Jean-Louis. Ver e Poder, a inocência perdida: cinema, televisão, ficção e documentário. Ed. UFMG: 2008.

DA-RIN, Silvio. Espelho Partido - tradição e transformação do documentário. Rio de Janeiro: Azougue Editorial, 2004.

DELEUZE, Gilles \& Guatari, Feliz. Postulados da Linguística in Mil Platôs Capitalismo e Esquisofrenia, Rio de Janeiro: Editora 34, 1995.

DOANNE, Mary Anne. A voz no cinema: a articulação do corpo e espaço. In: XAVIER, Ismail. Rio de Janeiro: Edições Graal: Embrafilme, 1983.

EDUARDO, Cléber. “Que país é esse?”, “Subjetividade: modo ou moda?”, “Obra em processo ou processo como obra:”, In: EDUARDO, Cléber; VALENTE, Eduardo; VIEIRA, João Luiz. Catálogo da mostra "Cinema brasileiro, anos 2000, 10 questões". São Paulo; Rio de Janeiro: Centro Cultural Banco do Brasil, 2011. .“Objetos sujeitos?”. Revista Cinética, maio de 2008. Disponível em: http://www.revistacinetica.com.br/docpersonagem.htm ."A mulher, o lixo e o mito - sobre Estamira, de Marcos Prado (2004)". In: revista Cinética, 2004. Disponível em: http://www.revistacinetica.com.br/estamira.htm

EHRENBERG, Alain. O culto da performance - da aventura empreendedora à depressão nervosa. São Paulo: Idéias e Letras, 2010. 
FELDMAN, Ilana. "Na contramão do confessional: o ensaísmo em Santiago, Jogo de cena e Pan-cinema permanente". In: MIGLIORIN, Cezar (org.) Ensaios no real. Rio de Janeiro: Azougue, 2010.

FRANCE, Claudine de. Cinema e antropologia. Papirus: Campinas, SP,1999.

FREIRE, Marcius. "Relação, encontro e reciprocidade: algumas reflexões sobre a ética no cinema documentário contemporâneo". In: Revista Galáxia, São Paulo, n. 14, p. 13 28, dez. 2007.

"Jean Rouch e a invenção do Outro no documentário". In: Doc On-line, n.03, p 55-65, dezembro 2007.Disponível em: www.doc.ubi.pt

FOUCAULT, Michel. “O que é um autor?”. In: Ditos e Escritos, vol. III, Rio de Janeiro: Forense, 2003.

GAUTHIER, Guy. Le documentaire - un autre cinéma. Paris: Armand Colin, 2011.

GOFFMAN. Erving. The Presentation os Self in Everyday Life. Nova York: Doubleday, 1959.

GUIMARÃES, César. "O retorno do homem ordinário do cinema". In: Revista Contemporânea, PÓSCOM, UFBA, vol.03, No.02, dez. 2005. Disponível em: www.contemporanea.poscom.ufba.br/pdfjan2006/contemporanea_n3v2_guimaraes.pdf "A singularidade como figura lógica e estética no documentário". In: Revista ALCEU - v.7 - n.13 - p. 38 a 48 - jul./dez. 2006. ."Comum, ordinário, popular: figuras da alteridade no documentário brasileiro contemporâneo”. In: MIGLIORIN, Cezar. Ensaios no Real. Rio de Janeiro: Azougue, 2010.

GINZBURG, Carlo. A micro-história e outros ensaios. Rio de Janeiro: Bertrand, 1989.

GORZ, André. O imaterial - conhecimento, valor e capital. São Paulo: Annablume, 2005 .

HOLANDA, Karla. "Documentário brasileiro contemporâneo e a micro-história". Devires, Belo Horizonte, Fafich/UFMG, v. 2, n.1, p. 86-101, jan-dez, 2004.

KAUFMANN, Jean-Claude. A invenção de si - uma teoria da identidade. Lisboa: Instituto Piaget, 2005. 
KRAKAUER, Sigmund. O Ornamento da Massa: Ensaios. São Paulo: Cosac \& Naif, 2007

LABAKI, Amir e MOURÃO, Maria Dora (orgs.) O Cinema do Real. São Paulo. Cosacnaify, 2005.

LEBLANC, Gerard. "L'auteur en question”. In: La Revue Documentaire, n 14, ediatada pela L'association La Revue Documentaire, Paris, 1999.

LINS, Consuelo. O documentário de Eduardo Coutinho. Rio de Janeiro: Jorge Zahar, 2004.

LINS, Consuelo e MESQUITA, Cláudia. Filmar o real - sobre o documentário brasileiro contemporâneo. Rio de Janeiro: Jorge Zahar, 2008.

MATTOS, Carlos Alberto. Eduardo Coutinho: o homem que caiu na real. Santa Maria da Feira, Portugal: Festival de Cinema Luso-Brasileiro de Santa Maria da Feira, 2003.

."Em Busca da Voz Legítima". In Cinemais, Revista de cinema e outras questões audiovisuais, Rio de Janeiro: Aeroplano, 2003.

MESQUITA, Claudia. Retratos em Diálogo. Notas sobre o documentário brasileiro recente. Novos Estudos: Cebrap: São Paulo, 2010.

"A superfície do cotidiano: uma aproximação a Acidente e Uma encruzilhada aprazível". In: MIGLIORIN, Cezar (org.) Ensaios no real. Rio de Janeiro: Azougue, 2010.

MIGLIORIN, Cezar. "Documentário recente brasileiro e a política das imagens". In: MIGLIORIN, Cezar (org.) Ensaios no real. Rio de Janeiro: Azougue, 2010.

MONTAIGNE, Michel. Ensaios. São Paulo: Abril Cultural, 1972

NAGIB, Lucia. A utopia no cinema brasileiro. São Paulo: CosacNaify, 2006.

NICHOLS, Bill. La representación de la realidad - Cuestiones y conceptos sobre el documental. Paidós: Buenos Aires, 1991.

.A voz do documentário". In: RAMOS, Fernão (org.). Teoria Contemporânea do Cinema - Documentário e Narratividade Ficcional, vol. II. São Paulo: Senac, 2005. 
OROCCHI, Luiz Zanin. Cinema de novo: um balanço crítico da retomada. São Paulo: Estação Liberdade, 2003.

RAMOS, Fernão (org). Teoria Contemporânea do Cinema, vol. II. São Paulo. Senac, 2005.

. Mas afinal o que é mesmo documentário? São Paulo: Senac, 2008.

."A mise em scène do documentário". In: Cine Documentário, Número 4, Año 2011, Argentina. Disponível em: http://revista.cinedocumental.com.ar/4/teoria.html

RENOV, Michel. The Subject of Documentary. Minneapolis: University of Minnesota Press, 2004.

SARLO, Beatriz. Tempo passado - cultura da memória e guinada subjetiva. São Paulo: Cia das Letras, 2007.

SCHECHNER, Richard. Performance studies: an introduction. Londres: Routledge, 2002

SCHEFER, Jean Louis. Le homme ordinaire au cinéma. Paris: Cahiers du cinema/Galimard, 1997.

SENRA, Stella. "Interrogando o documentário brasileiro". In: Sinopse - Revista de Cinema, $\mathrm{n}^{\circ}$ 10, ano IV, dez. 2004.

SIBILIA, Paula. O show do eu - a intimidade como espetáculo. Rio de Janeiro: Nova Fronteira, 2008.

TEIXEIRA, Francisco Elinaldo (org.) Documentário no Brasil - tradição $e$ transformação. São Paulo: Summus, 2004.

XAVIER, Ismail. O Discurso cinematográfico - a opacidade e a transparência. Rio de Janeiro: Paz e Terra, 2005.

"Indagações em torno de Eduardo Coutinho e seu diálogo com a tradição moderna". In: MIGLIORIN, Cezar (org.) Ensaios no real. Rio de Janeiro: Azougue, 2010.

2007.

Sertão Mar: Glauber Rocha e a estética da fome. São Paulo: Cosac Naify,

. O cinema brasileiro nos anos 90. Praga: Estudos Marxistas, 2009, n ${ }^{\circ} 9$.

. Encontros inesperados. Entrevista com Ismail Xavier. In: CONTI, Mario

Sergio. Folha de São Paulo: Editoria Mais: São Paulo, 3 dez, 2000. 